\title{
Study on the Adrenalectomy Based on the Tissue Respiration
}

\author{
By
}

\section{Takeo SEKIGUGHI}

\author{
Department of Internal Medicine, Kyoto Prefectural Medical College \\ (Director: Prof. S. Tateishi)
}

Chapter 1. Influence of the adrenalectomy upon the tissue respiration.

Experiments of the tissue respiration using male mouse undergoing unilateral adrenalectomy and of compensatory action of Cortisone and DOCA using male mouse undergoing bilateral adrenalectomy were carried out and the following results were obtained.

1) There was no difference between mouse, one week after the unilateral adrenalectomy, and the control in the tissue respiration of the each organ i.e., the liver, the kidney, the spleen and the luug.

2) Two weeks after the unilateral adrenalectomy, the tissue respiration of above-mentioned organs did not change particularly, but the tissue respiration of the kidney alone showed some tendency to decrease.

3) 2 days after the bilateral adrenalectomy, the tissue respiration of abovementioned organs did not show any difference compaired with the control.

4) 4 days after the bilateral adrenalectomy, the tissue respiration of the liver and the kidney tended to decrease, but the spleen and the lung did show no special difference.

5) After the bilateral adrenalectomy, in the case of administering Cortisone, the tissue respiration of the each organ showed the recovery.

6) In the case of administering DOGA after the bilateral adrenalectomy, the tissue respiration of the liver tended to decrease, and that of the kidney, of the spleen and of the lung did not show any difference from the control.

7) The death-rate was $42 \%$ for the first four days after the bilateraly adrenalectomy, the group administered Cortisone after the extraction was low in death-rate, the group administered DOCA after the extraction was $40 \%$, and there was no special difference between the non-managed group and the DOCA administered group.

Chapter 2. Influence upon the tissue respiration of some organs of the animal undergoing adrenalectomy in low and high temperature.

In the case of giving stress of temperature to the adrenalectomized animal, studies on the tissue respiration of the liver and the kidney, and on the influence of administering ACTH, Cortisone and DOCA upon the tissue respiration were carried out and the following results were obtained.

1) In low temperature, the tissue respiration of the liver of the unilaterally adrenalectomized animal decreased a little, and that of the kidney also showed the tendency of decreasing.

2) In low temperature, the tissue respiration of the liver of the animal with the partial adrenal gland remained decreased, and the tissue respiration of the kidney also showed the tendency of de- creasing.

3) In low tc:aperature, the administering of ACTH and Cortisone to the animal with the partial adrenal gland remained made the tissue respiration of the liver and the kidney recover.

Vol. 33 No. 9 
4) In low temperature, the tissue respiration of the liver of the animal with the partial adrenal gland remained showed the tendency of decreasing in some degree when the animal was administered DOCA, and that of the kidney also showed the tendency of decreasing.

5) In high temperature, the tissue respiration of the liver of the animal with the partial adrenal gland remained, tended to decrease, and the tissue respiration of the kidney also showed the tendency of decreasing.

6) In high temperature, the tissue respiration of the liver of the bilateral adrenalectomized animal remarkably decreased, and that of the kidney also showed the tenddency of decreasing.

7) In high temperature, the administering of Cortisone to the bilateral adrenalectomized animal made the tissue respiration of the liver and the kidney recover.

8) In high temperature, the administering of Cortisone to the bilateral adrenalectomized animal tended to decrease the tissue respiration of the liver, and made the tissue respiration of the kidney recover.

9) In low temperature, the group of the bilateral adrenalectomized is the highest in the death-rate, second is the group of the animals with the partial adrenal gland remained, and third is the group of the unilateral adrenalectomized. Of the group of the animals with the adrenal glands partially remained, the animals administered Cortisone was the lowest in the death-rate, and the animals administered ACTH was the next and the animals administered DOCA was the last.

10) Concerning the animals after adrenalectomized in high temperature, the death-rates of the group of the bilateral adrenalectmized and the group with the adrenal glands remained was equally apoximately $50 \%$, so high percentage, and that of the bilateral adrenalectomized when administered Cortisone showed that the giving was very effective, but DOCA did hardly take the effect.

Chapter 3. Influence of the adrenalectomy upon the tissue respiration of endocrine organs.

From the study of the tissue respiration of the both organs of male and female rat administered Cortisone and DOGA after the the operation of the bilateral adrenalectomy, and from the study of the relation between adrenalectomy and weight of thymus of male rat, I got the following results:

1) The tissue respiration of hypophysis of the animal that has been operated the bilateral adrenaiectomy did not under go remarkable change.

2) The tissue respiration of hypophysis of the animal administered Cortisone or DOCA after the operation of the bilateral adrenalectmy did not undergo remarkable change.

3) The tissue respiration of thyroid of the bilateral adrenalectomized did not show particularly the tendency of increasing.

4) The tissue respiration of thyroid of the animal administered Cortisone or DOCA after the operation of the bilateral adrenalectomy showed no particular tendency of decreasing.

5) The tissue respiration of thymus of the animal that has undergone the bilateral adrenalectomy showed particular sign of increasing.

6) The tissue respiration of thymus of the animal administered Cortisone after the operation of the bilateral adrenalectomy showed the remarkable sign of decreasing, the tissue respiration of thymus of the animal administered DOCA showed the slight tendency of increasing.

7) The weight of thymus of the animal that has undergone the bilateral adrenalectomy remarkably increased, and it decreased particularly when administered Cortisone after the operation of the adrenalectomy, and increased when administered DOCA.

8) The tissue respiration of testicle of the animal that has undergone the bilateral adrenalectomy

Vol. 33 No. 9 
showed in some degree the tendency of decreasing.

9) The tissue respiration of testicle of the animal administered Cortisone after the operation of the bilateral adrenalectomy recovered, but it decreased when administered DOCA.

10) The tissue respiration of the ovary of the animal that has undergone the bilateral adrenalectomy showed in some degree the tendency of decreasing.

11) The tissue respiration of the ovary of the animal that has undergone the bilateral adrenalectomy recovered when administered Cortisone or DOCA.

\section{Diabetes mellitus and Size of Profil Area on X-ray Film of Sella turcica}

By

\section{Mitsuhisa HAYAKAWA, Ryojiro MIKAMI, Buichi KIMURA and Yosimi NAKAGAWARA}

(From the Medical Clinic of Prof. H. Matunaga, School of Medicine, Hirosaki University)

Real size of profil area of sella turcica $\left(\mathrm{cm}^{2}\right)$ was measured on 46 diabetic patients, 16 women and 30 men, through planimetry of its figure on x-ray film obtained by "round sight rotatography" and mathematical conversion. 22 patients (48 per cent) gave smaller value than 0.80 , and 19 patients did so larger one than 0.91 (41 per cent), while the size of most of healthy persons had been reported to be implied in the range of $0.81-0.9$.

The distribution of age of onset among those having smaller sella showed two peaks, one being found before 30 and the other after 41, and that among those having larger one showed only one peak which were found after 40 among women or 50 among men respectively. Observations were, therefore, made by dividing the patients into 3 groups according to onset age on one hand and size of sella on the other: Those having large sella of over 0.81 (group I) and those having small sella of under 0.80 and onset in advanced age of after 31 years (group II) or in younger age of before 30 years (group III). Refer to the latter two groups, however, 7 out of 8 cases of group III and 4 out of 14 cases of group II were found with value smaller than 0.65. Therefore, average size of sella of each group compared in this order of the magnitude: $1>$ II $>$ III.

Those belonging to group III were found chiefly among those whose fasting blood sugar were found higher than $180 \mathrm{mg} / \mathrm{dl}$ and urine quantity over 3,000 cc. per day. Among those of group II more were found with low blood sugar and without polyuria than among those of group I. Refer to the group II, more were found with obesity and relatively low blood sugar among women than among men, and more were asthenic in type and found with high blood sugar among men than amog women.

Retinitis or retinal hemorrhage was found more frequently in those of group I, and tuberculosis, catalacta or nephritic singns was so in those of groups I and II. Vascular hypertension was, however, more frequently seen in those being obesed and having small sella or in those being asthenic in type and having large sella than in the other.

7 cases were seemed to be relatively resistent to insulin as the drop in blood sugar after injection of 5 units was, on each of them, below $30 \mathrm{mg} / \mathrm{dl}$, and 6 cases out of these were those belonging to group $\mathrm{I}$.

That sella turcica of diabetic patients was, as above mentioned, often too small or too large suggested 


\title{
組織呼吸を基調とせる副腎摘出に関する研究
}

\author{
京都府立医科大学内科学教室 (指導 舘石教授) \\ 研究科学生 医学士 関口孟男
}

（本論交要旨は第29回及び第30回日本内分泌学会に於て発表した）

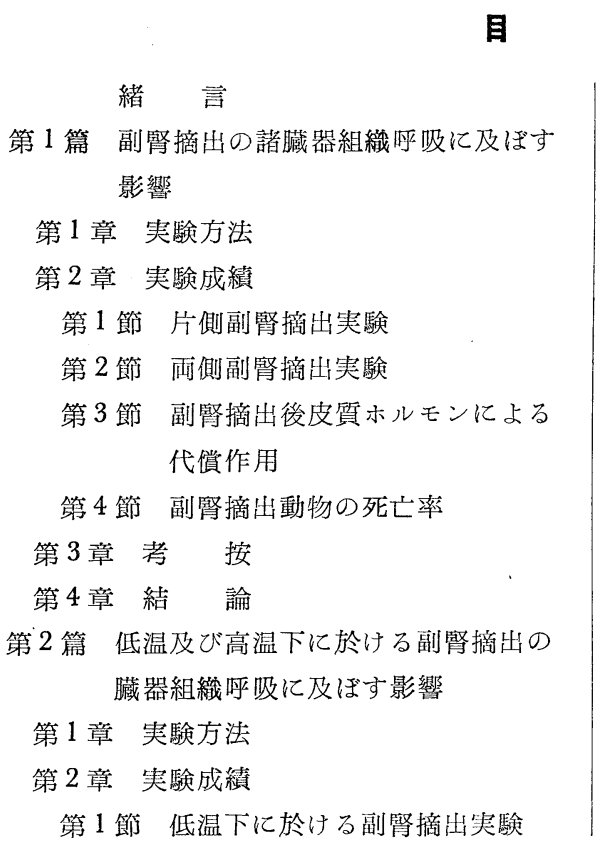

緒
次

\author{
第 2 節 高温下に於ける副霄摘出実験 \\ 第 3 節 低温及び高温下に於ける副腎摘 \\ 出動物の死亡率
}

第 3 章 考 按

第 4 章 結 論

第 3 篇 副警摘出の內分泌臟器組織呼吸に及 ぼす影響

第 1 章 実験方法

第 2 章 実験成結

第 1 節 両側副腎摘出実験

第 2 節 副腎摘出後皮質ホルモンによる

代償作用

第 3 節 副眭摘出之胸腚重量

第 3 章 考 按

第 4 章 結 論

引用交献

副督が生命の維持に重大なる意義を有する事及び副算摘浽に上る動物の致死が副腎皮質機能の脱落に因る ものである事は幾多先人の業績の示す所である. 近年 Kendall, Wintersteiner, Steiger \& Reichstein 等の研究に より，副堅皮質 Hormone の確実な知見を得ると同時に Selye ${ }^{1)}$ (1936) による “General Adaptation Syndrome” なる概念か導入されて以来，諸多の傷害刺㦸，所謂 “Stress”を起す作因に関して结，種々の動物実 験及び臨牀所見に基いて数多くの研究成績が報告されている.

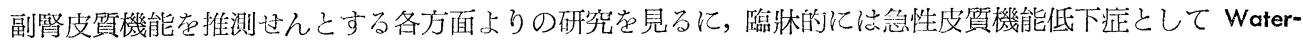
house-Friedrichsen 氏症状群，慢性皮質機能低下症として Addison 氏病が学げられ，皮質機能元進症としては Cushing 氏症状群及び副腎生殖器症状群等が゙敬げられて居り, 夫々各疾患に関して詳細なる检索が進められ

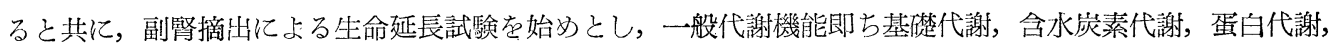
塩類代謝, 水分代謝等に及ぼす影響, 其他各種内分泌腺及び各種藏器に及ぼす影響が種々の観点より研究さ れている。また副腎自体が告体防衛機轱に重要な役割を占めている点より，所謂非特異的作因を負荷したる 場合の副腎の態度，各種内分泌腺との関係，其の他各種副筒皮筫 Hormone の作用機序及び生体に対する影 響等に関しても，内外共に其の文献が救挙にいとまなき事は今更云うまでもない.

私は先人が軽視して抽つた組織呼吸の面に着眼し，副腎摘出が動物の各種臟器及び内分泌腺に及ばす影響 
並びに副腎皮質 Hormone として Cortisone acetate 及び Desoxycorticosterone acetate の代償作用及び一 部副腎を残して実験に供した動物に，此の副腎皮筫 Hormone のほかに Adrenocorticotrophic hormone を 投与した場合，如何なる影響を及ぼすかを知らんとし本実験を企図した。ての際 Stress として代表的なも のにあげられている高温及び低温を負荷し，之が副筒摘出動物に及ぼす影響及び上述の各種 Hormone の代 償作用の解明に努め，且つ副㛑摘出及び Stress を負荷した摘出動物の死亡率並びに副緊摘出の胸腺重量に 及ぼす影響に就いて実験を行い，興味ある成績に到達したので以下報告する。

\section{第 1 編 副腎摘出の諸臟器組織呼吸に及ぼす影響}

\section{第 1章 実 験 方 法}

1）実験動物として体重 15〜20g の雄性二十日鼠を用い，副腎摘出手術访脊部皮膚を切開する事により行 い，対照動物には副腎を摘出せ如範囲で同様な手術的侵害を加えた。摘出及び対照手術共に麻酔は全く使用 せず，両側一次的摘出法によつた，実験動物の飼育温度は出来得る限り $15 \sim 20^{\circ} \mathrm{C}$ 前後に保ち，且つ飼料は大 麦，魚粉及び野菜と水を与えた。副腎摘出動物には $1 \%$ 食塩水を投与した.

2) 片側副腎摘出実験に於いては，左側副篎摘出微 1 週経過群，同じく 2 週経過群及び两群の対照手術群 の 4 群に分ち，各群共化手術後夫々日数を経過せるものを撲殺し，直に朋臟，腎藏，脾蔵及び肺臓を取り出 し実験に供した。

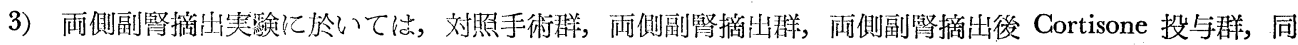
しく DOGA 投与群の 4 群に分ち, 各群共に手術後 4 日経過せるものを撲殺し, 直に肝臟, 腎臓, 脾藏及び 肺臓を取り出し実験に供した。 Cortisone は Scheroson（Schering）を副腎摘出後，毎日1.25mg宛 4 回腹腔 内に投与し，DOGA は Syncorta (Takeda) を每日0.025mg宛 4 回㾞部皮下に注射した。

4) 組織呼吸測定に Warburg 氏検圧法によつた。

a）浮遊液 : $0.90 \% \mathrm{NaCl}, 1.10 \% \mathrm{KCl}, 1.30 \% \mathrm{CaCl}_{2}$ 及び $1.32 \% \mathrm{NaHCO}_{3}$ の各溶腹を予作成し，使 用に際し $\mathrm{NaCl}$ 溶液 $100 \mathrm{cc}$ 並びに $\mathrm{KCl}, \mathrm{CaCl}_{2}$ 及び $\mathrm{NaHCO}_{3}$ 各溶液 $2 \mathrm{cc}$ 宛を混合して Warburg 氏組織呼 吸用 Ringer 氏液とす。

b）実験操作：実験動物を頸部打撲により致死せしぬ，直に所要各臟器組織を鋭利なる剃刀を以つて可及 的薄い切片を作成し，其の数片を予め準備せる呼吸槽主室浮遊液中に入れ，副室には $5 \% \mathrm{KOH}$ 溶液を入れ る，呼吸測定時には manometer に接続せる呼吸槽容器中の栄幾を酸素にて置換し，次いで38Cの恒温槽中 に入れ之れを振撃し，呼吸槽中の内圧が外気圧と平衡したる後30分，60分の 2 回に互り呼吸容器中の酸素減 少量を manometer の分圧差により測定した。

c）計算 : 呼吸槽中の消費酸素量は manometer の圧力差により次式に基づき計算した。

$$
\begin{aligned}
\mathrm{Qo}_{2} & =\frac{\mathrm{Xo}_{2}}{\mathrm{mt}} \\
\mathrm{Xo}_{2} & =\text { h. } \mathrm{Ko}_{2}
\end{aligned}
$$

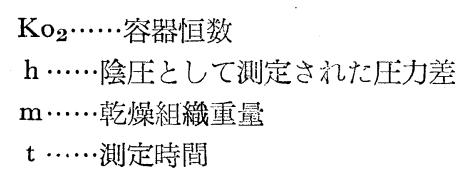

\section{第 2 章 実 験 成 績}

\section{第 1 節 片側副監摘出実験}

1) 片側副腎摘出対照手術後 1 週経過せるもの>肝臟，腎藏，脾藏及び肺藏の各臓器組織呼吸を検べた成 績は次の如くで西る（第 1 表）。 
第 1 表 片側副腎摘出対照手術後 1 週経過群に於ける諸臟器 Q Q 2

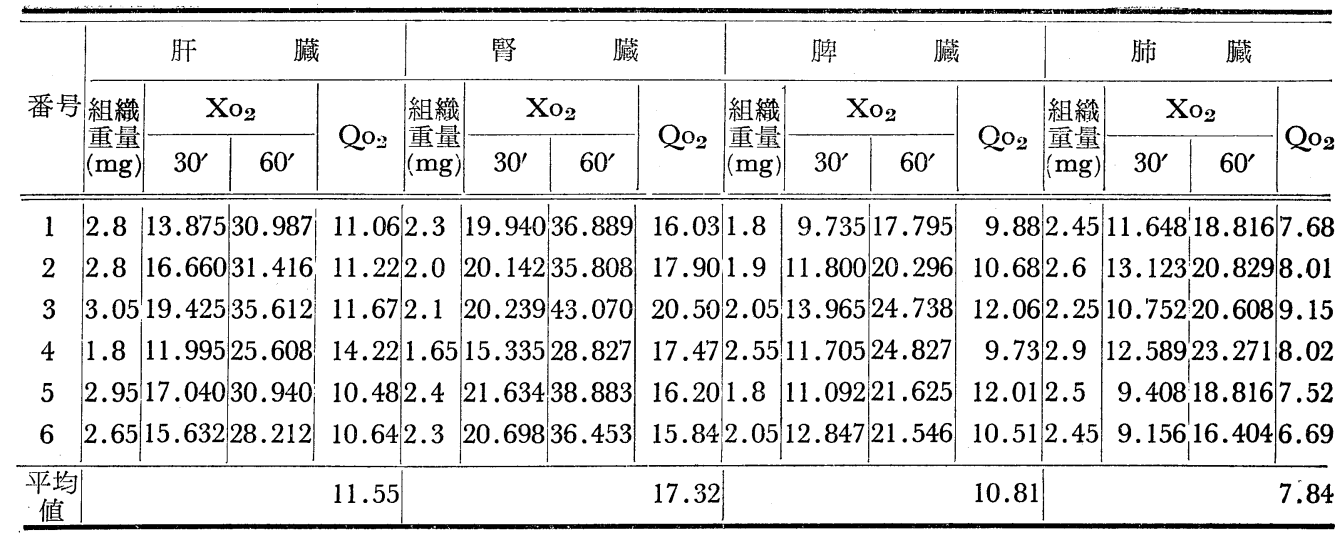

\section{a) 䀒藏}

Ringer 氏液中の肝藏組織呼吸は 6 例中最大值 14.22 ，最小值 10.48 亿て平均値は11.55である。

\section{b) 腎藏}

Ringer 氏液中の筲臓組織呼吸は 6 例中最大值20.50，最小值15.84にして平均值は17.32である。

\section{c) 脾臟}

Ringer 氏液中の脾臟組織呼吸は 6 例中最大值12.06, 最小值9.73にして平均值は10.81でする。

\section{d) 肺㼩}

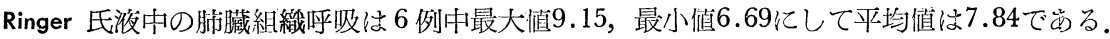

2) 片側副腎摘出㷋 1 週経過せるもの>肝藏, 腎藏, 脾藏及び肺藏の 各臓器組織呼吸は次の如くである (第 2 表).

第 2 表 片側副腎摘出後 1 週経過群に於ける諸藏器 $\mathrm{QO}_{2}$

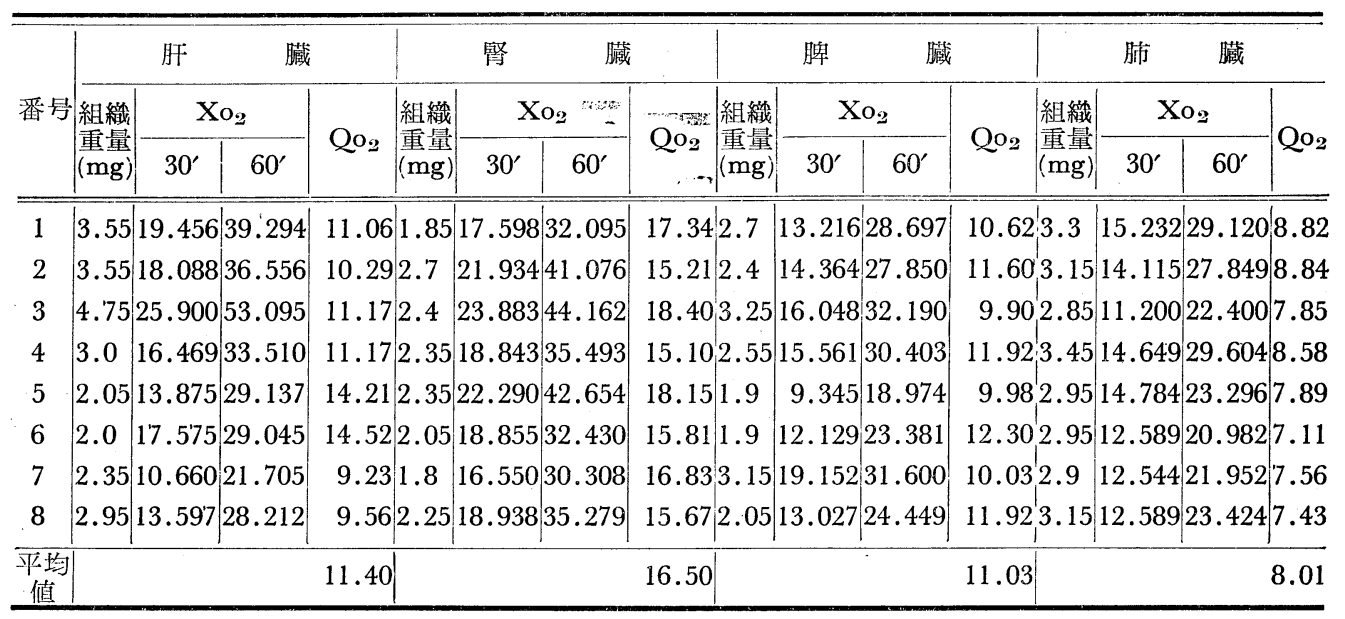

\section{a) 䀒藏}

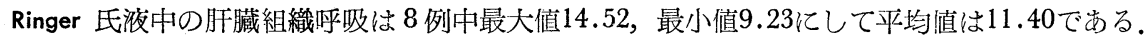

\section{b) 腎臟}

Ringer 氏液中の腎臓組織呼吸は 8 例中最大值 18.40 , 最小值 15.10 てして平均值は16.50である。 


\section{c) 脾臓}

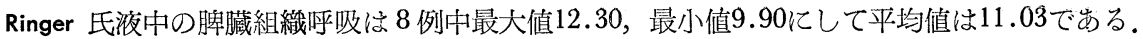

\section{d) 肺䍣}

Ringer 氏腹中の肺藏組織呼吸は 8 例中最大值8.84，最小值7.11にして平均值は8.01である.

3) 片側副腎摘出対照手術後 2 週経過せるもの>肝藏，督臟，脾藏及び肺藏組織呼吸仿次の如くである (第 3 表).

第3 表 片側副腎摘出対照手術後 2 週経過群に於ける諸藏器 $\mathrm{Qo}_{2}$

\begin{tabular}{|c|c|c|c|c|c|c|c|c|c|c|c|c|c|c|c|c|}
\hline \multirow{3}{*}{$\begin{array}{c}\text { 番号 } \\
\text {. }\end{array}$} & \multicolumn{2}{|r|}{ 肝 } & \multicolumn{2}{|c|}{ 藏 } & \multicolumn{2}{|r|}{ 䴛 } & \multicolumn{2}{|c|}{ 臟 } & \multicolumn{2}{|r|}{ 脾 } & \multicolumn{2}{|c|}{ 臟 } & \multicolumn{2}{|r|}{ 肺 } & \multicolumn{2}{|l|}{ 臟 } \\
\hline & \multirow{2}{*}{$\left|\begin{array}{l}\text { 組織 } \\
\text { 重量 } \\
(\mathrm{mg})\end{array}\right|$} & \multicolumn{2}{|c|}{$\mathrm{Xo}_{2}$} & \multirow{2}{*}{$\mathrm{Qo}_{2}$} & \multirow{2}{*}{$\left|\begin{array}{l}\text { 組織 } \\
\text { 重量 } \\
\text { mg }\end{array}\right|$} & \multicolumn{2}{|c|}{$\mathrm{Xo}_{2}$} & \multirow{2}{*}{$\mathrm{Qo}_{2}$} & \multirow{2}{*}{$\begin{array}{l}\text { 組織 } \\
\text { 重量 } \\
(\mathrm{mg})\end{array}$} & \multicolumn{2}{|c|}{$\mathrm{Xo}_{2}$} & \multirow{2}{*}{$\mathrm{Qo}_{2}$} & \multirow{2}{*}{$\begin{array}{l}\text { 組織 } \\
\text { 重量 } \\
(\mathrm{mg})\end{array}$} & \multicolumn{2}{|c|}{$\mathrm{Xo}_{2}$} & \multirow{2}{*}{$\mathrm{Qo}_{2}$} \\
\hline & & $30^{\prime}$ & $60^{\prime}$ & & & $30^{\prime}$ & $60^{\prime}$ & & & $30^{\prime}$ & $60^{\prime}$ & & & $30^{\prime}$ & $60^{\prime}$ & \\
\hline
\end{tabular}

\begin{tabular}{l|l|l|l|l|l|l|l|l|l|l|l|l|l|l|l|l|l|l|l|l|l|l|l|}
1 & 2.7 & 12.852 & 27.988 & 10.36 & 1.85 & 19.441 & 38.583 & 20.85 & 1.8 & 10.384 & 21.051 & 11.69 & 2.35 & 9.856 & 19.7128 .38 \\
\hline
\end{tabular}

\begin{tabular}{l|l|l|l|l|l|l|l|l|l|l|l|l|l|l|l|l|l|l|l|l|l|l|}
2 & 2.95 & 16.660 & 29.607 & 10.03 & 1.5 & 14.665 & 27.570 & 18.38 & 2.45 & 12.744 & 23.316 & 9.51 & 2.0 & 8.512 & 15.232 & 7.61
\end{tabular}

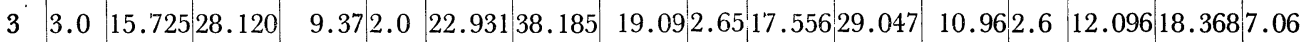

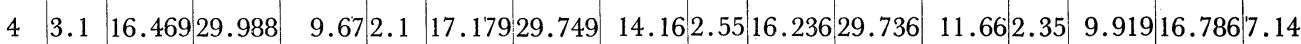

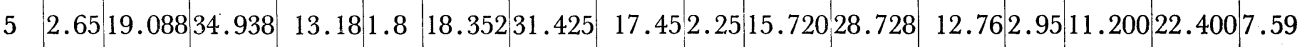

\begin{tabular}{l|l|l|l|l|l|l|l|l|l|l|l|l|l|l|l|l|l|l|l|l|}
6 & 2.65 & 19.887 & 39.312 & 14.83 & 1.65 & 15.922 & 30.503 & 18.482 .05 & 12.744 & 26.526 & 12.93 & 3.1 & 12.589 & 25.0268 .07
\end{tabular}

\begin{tabular}{l|r|r|r|r}
\hline $\begin{array}{c}\text { 平均 } \\
\text { 值 }\end{array}$ & 11.24 & 18.06 & 11.58 & 7.64 \\
\hline
\end{tabular}

\section{a) 肝贜}

Ringer 氏液中の肝蔵組織呼吸は 6 例中最大值14.83，最小值9.37にして平均値は11.24である。

\section{b) 腎臟}

Ringer 氏液中の腎藏組織呼吸は 6 例中最大値 20.85 , 最小值 14.16 亿し平均值は18.06である。

\section{c) 睥䁍}

Ringer 氏液中の脾臓組織呼吸は 6 例中最大值 12.93 , 最小值 9.51 にて平均值は11.58である.

\section{d）肺贜}

Ringer 氏液中の肺臟組織呼吸は 6 例中最大值8.38，最小值'7.06亿して平均值は7.64である。

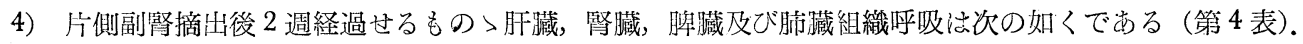

第 4 表 片側副腎摘出後 2 週経過群に於ける諸藏器 Qog

\begin{tabular}{|c|c|c|c|c|c|c|c|c|c|c|c|c|c|c|c|c|}
\hline \multirow{3}{*}{ 番号 } & \multicolumn{2}{|r|}{ 肝 } & \multicolumn{2}{|c|}{ 臟 } & \multicolumn{2}{|r|}{ 腎 } & \multicolumn{2}{|c|}{ 臟 } & \multicolumn{2}{|r|}{ 脾 } & \multicolumn{2}{|c|}{ 臟 } & \multicolumn{2}{|r|}{ 脑 } & \multicolumn{2}{|l|}{ 臟 } \\
\hline & \multirow{2}{*}{ 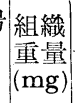 } & \multicolumn{2}{|c|}{$\mathrm{Xo}_{2}$} & \multirow{2}{*}{$\mathrm{Qo}_{2}$} & \multirow{2}{*}{$\begin{array}{l}\text { 組緎 } \\
\text { 重量 } \\
(\mathrm{mg})\end{array}$} & \multicolumn{2}{|c|}{$\mathrm{Xo}_{2}$} & \multirow{2}{*}{$\mathrm{Qo}_{2}$} & \multirow{2}{*}{$\begin{array}{l}\text { 組織 } \\
\text { 重量 } \\
(\mathrm{mg})\end{array}$} & \multicolumn{2}{|c|}{$\mathrm{Xo}_{2}$} & \multirow{2}{*}{$\mathrm{Qo}_{2}$} & \multirow{2}{*}{$\begin{array}{l}\text { 組縡 } \\
\text { 重量 } \\
(\mathrm{mg})\end{array}$} & \multicolumn{2}{|c|}{$\mathrm{Xo}_{2}$} & \multirow{2}{*}{ Qo. } \\
\hline & & $30^{\prime}$ & $60^{\prime}$ & & & $30^{\prime}$ & $60^{\prime}$ & & & $30^{\prime}$ & $60^{\prime}$ & & & $30^{\prime}$ & $60^{\prime}$ & \\
\hline
\end{tabular}

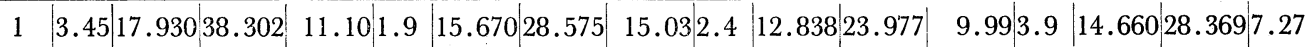

\begin{tabular}{l|l|l|l|l|l|l|l|l|l|l|l|l|l|l|l|l|l|l|l|l|l|}
2 & 2.4 & 11.648 & 25.536 & 10.64 & 1.7 & 17.262 & 31.341 & 18.43 & 2.9 & 14.842 & 30.084 & 10.37 & 3.15 & 14.337 & 24.975 & 7.92
\end{tabular}

\begin{tabular}{l|l|l|l|l|l|l|l|l|l|l|l|l|l|l|l|l|l|l|l|l|l|l|l|l|}
3 & 2.55 & 18.464 & 36.471 & 14.30 & 1.7 & 14.157 & 26.121 & 15.36 & 3.0 & 16.917 & 32.558 & 10.85 & 3.1 & 12.096 & 20.608 & 6.64
\end{tabular}

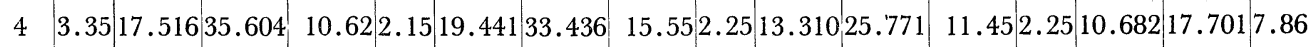

\begin{tabular}{l|l|l|l|l|l|l|l|l|l|l|l|l|l|l|l|l|l|l|l|l|}
5 & 2.95 & 18.870 & 35.705 & 12.10 & 1.95 & 16.949 & 33.399 & 17.12 & 2.15 & 13.645 & 24.817 & 11.54 & 2.4 & 9.228 & 16.1286 .72
\end{tabular}

\begin{tabular}{l|l|l|l|l|l|l|l|l|l|l|l|l|l|l|l|l|l|l|}
6 & 3.0 & 15.262 & 31.912 & 10.63 & 1.8 & 15.084 & 27.654 & 15.36 & 1.7 & 10.374 & 19.950 & 11.73 & 2.7 & 9.919 & 20.219 & 7.48
\end{tabular}

\begin{tabular}{cr|r|r|r}
\hline $\begin{array}{c}\text { 平均 } \\
\text { 值 }\end{array}$ & 11.57 & 16.14 & 10.99 & 7.31 \\
\hline
\end{tabular}




\section{a) 䀒臟}

Ringer 氏液中の肝藏組織呼吸は 6 例中最大值 14.30 , 最小值 10.62 にて平均值は11.57である。

b) 腎臟

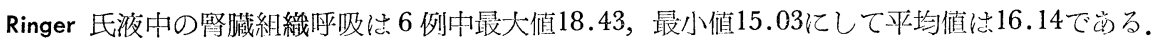

c) 脾臟

Ringer 氏液中の脾蔵組織呼吸さ 6 例中最大值 11.73 , 最小値9.99亿して平均值は10.99でらる。

d) 肺贜

Ringer 氏液中の脑臟組織呼吸は 6 例中最大值7.92, 最小傎6.64にして平均值は7.31である。

5) 本節小括

雄性二十日鼠の片側副婜摘出㷋 1 週及び 2 週経過せるもの>各臟器組織呼吸を測定した結果，次の成績を 得た（第 5 表，第 6 表).

第 5 表 片側副腎摘出後 1 週経過群の各臓器組織呼吸

\begin{tabular}{|c|c|c|c|c|c|c|c|c|c|}
\hline & 例数 & 肝 臟 & $\pm \%$ & 腎 藏 & $\pm \%$ & 脾 臟 & $\pm \%$ & 肺藏 & $\pm \%$ \\
\hline 対照手術群 & 6 & 11.55 & & 17.32 & & 10.81 & & 7.84 & \\
\hline 片側副粲摘出群 & 8 & 11.40 & $-1.2 \%$ & 16.50 & $-4.7 \%$ & 11.03 & $+2.0 \%$ & 8.01 & $+2.1 \%$ \\
\hline
\end{tabular}

第 6 表 片側副腎摘出後 2 週経過群の各臟器組織呼吸

\begin{tabular}{|c|c|c|c|c|c|c|c|c|c|}
\hline & 例数 & 肝 臟 & $\pm \%$ & 霜 臓 & $\pm \%$ & 脾 臟 & $\pm \%$ & 肺 臓 & $\pm \%$ \\
\hline 対照手術群 & 6 & 11.24 & & 18.06 & & 11.58 & & 7.64 & \\
\hline 片側副腎摘出群 & 6 & 11.57 & $+2.9 \%$ & 16.14 & $-10.6 \%$ & 10.99 & $-5.0 \%$ & 7.31 & $-4.3 \%$ \\
\hline
\end{tabular}

a) 片值副腎摘出後 1 週経過群の肝藏組織呼吸の平均值は11.40にして，站照値11.55との間に差を認めず。 2 過経過群の肝藏組織呼吸の平均值も11.57亿して, 対照值 11.24 と間に殆んどその差を認めない.

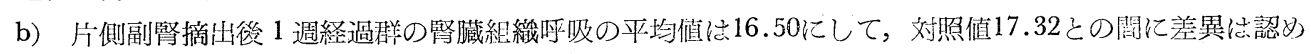

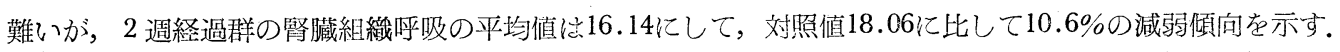

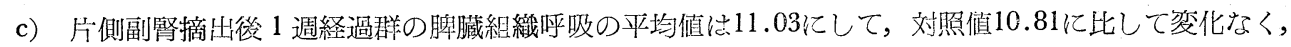
2 週経過群の脾臟組織呼吸の平均值は10.99にして，对照值11.58に比してー5\%の差異を示すも殆んど其の 差を認め難い.

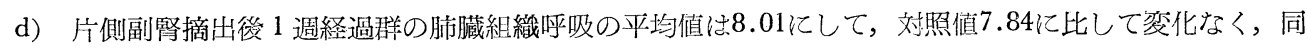
じく2 週経過群の肺臟組織呼吸の平均值に7.31にして, 対照値7.64に比して殆んど其の間に差異を認めない.

\section{第 2 節 両側副腎摘出実験}

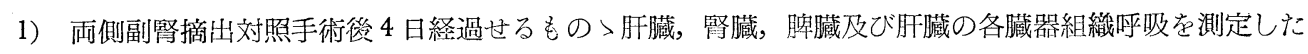
結果は次の如くである (第 7 表).

a) 肝贜

Ringer 氏液中の肝蔵組織呼吸は10例中最大值 15.00 , 最小值 10.55 亿して平均值は12.10である。

b）腎藏

Ringer 氏液中の腎藏組織呼吸ほ10例中最大值20.42, 最小值14.95亿して平均值は16.91である.

c) 脾臟

Ringer 氏液中の脾㵴組織呼吸は10例中最大值13.21，最小值10.18亿して平均值は11.38である, 
第 7 表 雨側副腎摘出対照手術群に於ける諸藏器 $\mathrm{Qo}_{2}$

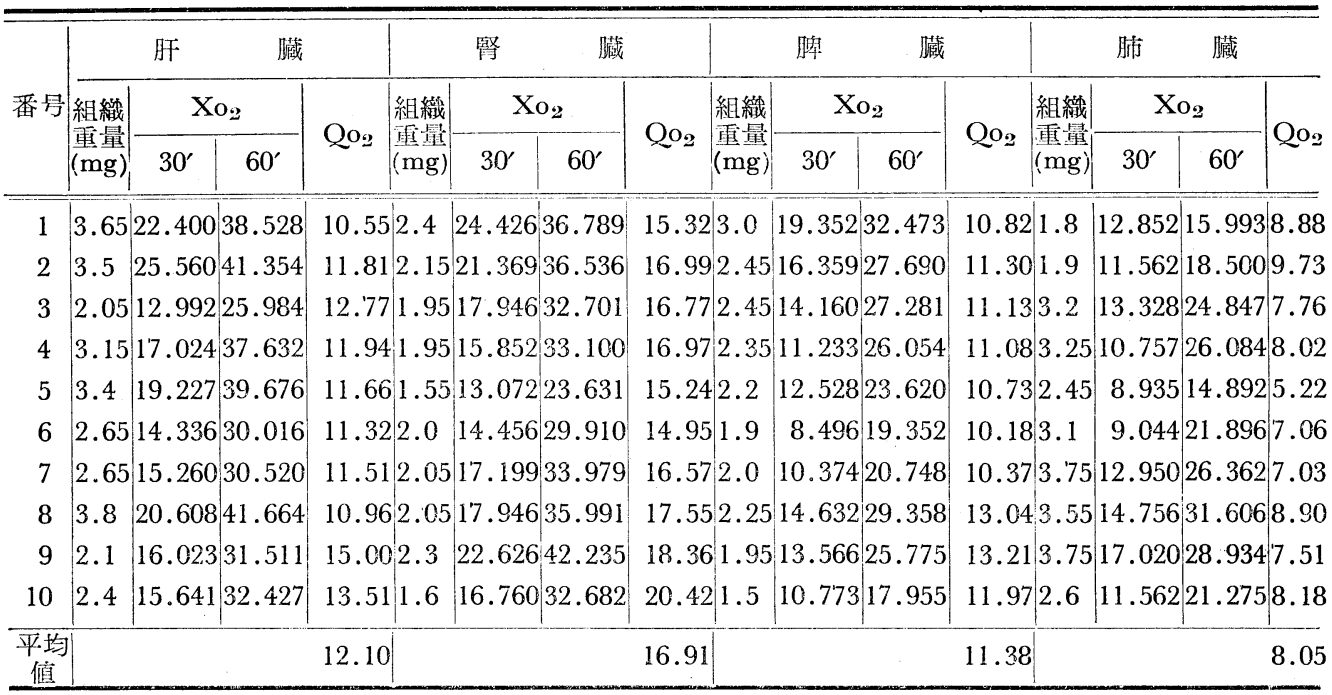

\section{d) 肺臟}

Ringer 氏液中の肺蔵紀織呼吸は10例中最大值9.73, 最小值5.22にして平均值は8.05で岕る。

2) 雨側副腎摘出後の各藏器組織呼吸

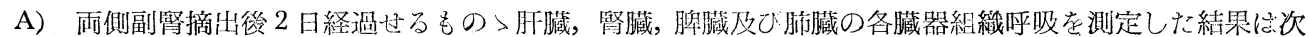
の如くである (第 8 表).

第 8 表 両側副腎摘出後 2 日経過群に於ける諸藏器 $\mathrm{Qo}_{2}$

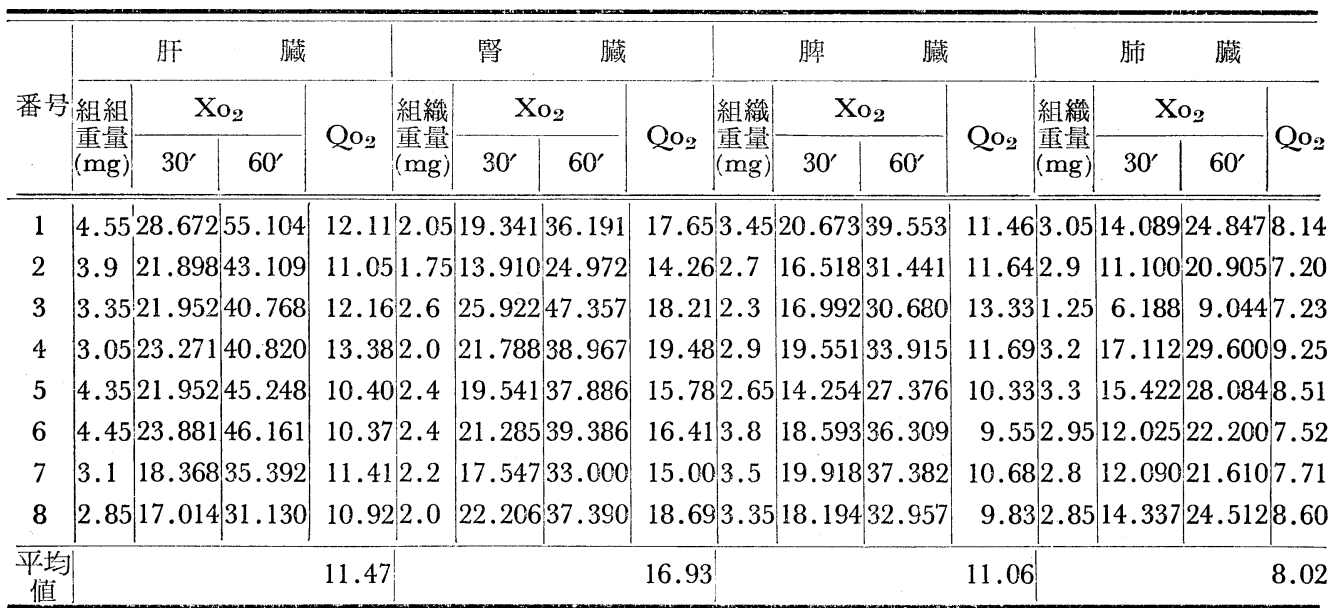

\section{a) 䀒臟}

Ringer 氏液中の肝蔵組織呼吸は 8 例中最大值13.38，最小值10.37にしで平均值は11.47である。

\section{b) 腎臟}

Ringer 氏液中の㛑臟組織呼吸は 8 例占最大值19.48，最小值14.26にして平均值は16.93である。 c) 脾欌 
Ringer 氏液中の脾臟組織呼吸は 8 例中最大値 13.33 ，最小値9.55にして平均值は11.06である。

\section{d) 肺裁}

Ringer 氏液中の肺臓組織呼吸は 8 例中最大值9.25，最小值7.20にして平均值は8.02である。

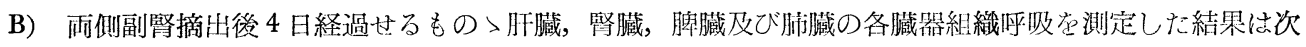
の如くである (第 9 表).

第 9 表 雨側副腎摘出後 4 日経過群に於ける諸臟器 $\mathrm{Qo}_{2}$

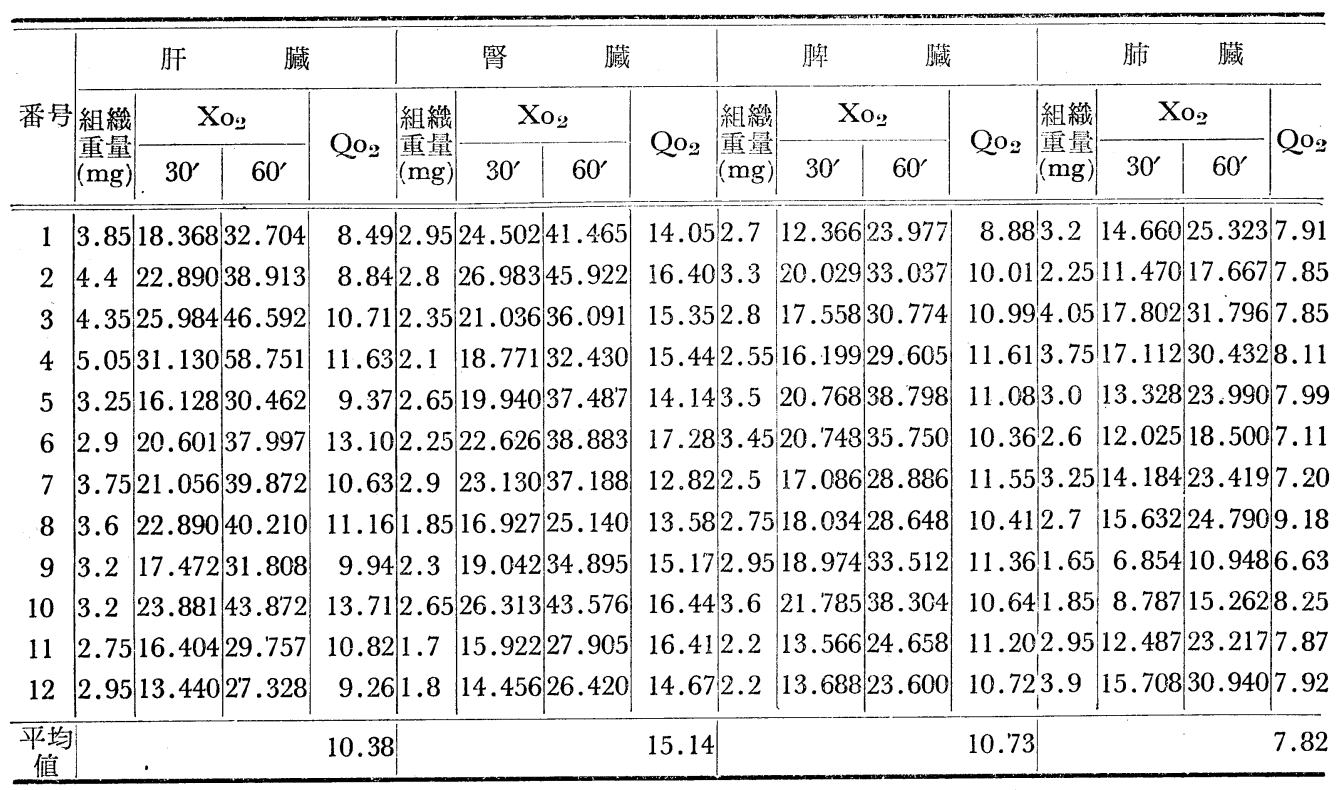

\section{a) 䀒践}

Ringer 氏液中の肝臟組織呼吸は12例中最大值 13.71 ，最小值8.49飞して平均值は10.38でらる。

\section{b）婜䐵}

Ringer 氏液中の腎臟組織呼吸は12例古最大值 17.28 ，最小值12.82にして平均值は15.14である。

\section{c) 脾臟}

Ringer 氏液中の脾蔵組織呼吸は12例中最大值11.61，最小値8.88にして平均值は10.73である。

\section{d) 肺臓}

Ringer 氏液中の肺臓組織呼吸さ12例中最大值9.18，最小値6.63にして平均值さ7.82でする。

3) 本節小括

雄性二十日鼠の両側副腎摘出後 2 日及び 4 日経過せるもの>各臟唯組織呼吸を測定した結果, 次の成績を 得た（第10表).

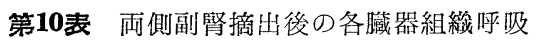

\begin{tabular}{|c|c|c|c|c|c|c|c|c|c|}
\hline & 例数 $\mid$ & 肝臟 & $\pm \%$ & 粲臟 & $\pm \%$ & 脾臓 & $\pm \%$ & 肺藏 & $\pm \%$ \\
\hline 対照手術群 & 10 & 12.10 & & 16.91 & & 11.38 & & 8.05 & \\
\hline 両側副腎摘出後 2 日経過群 & 8 & 11.47 & $-5.2 \%$ & 16.93 & $+0.1 \%$ & 11.06 & $-2.8 \%$ & 8.02 & $-0.3 \%$ \\
\hline 両側副腎摘出後 4 日経過群 & 12 & 10.38 & $-14.2 \%$ & 15.14 & $-10.4 \%$ & 10.73 & $-5.7 \%$ & 7.82 & $-2.8 \%$ \\
\hline
\end{tabular}




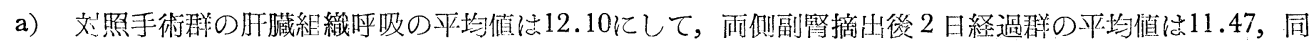
ビく 4 日経過群の平均值は10.38亿して対照に比して夫々 $5.2 \%$ 及び $14.2 \%$ 減少を認めた.

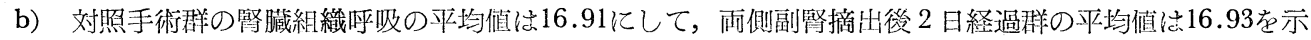

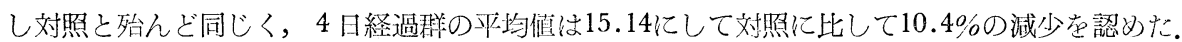

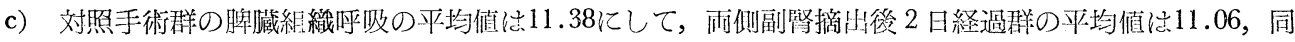

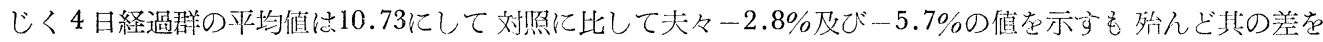
見ない.

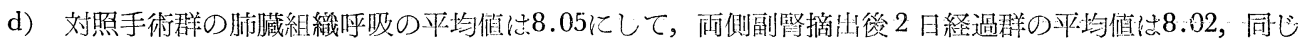
く4 日経過群の平均值ば7.82にして対照に比して夫々 $-0.3 \%$ 及び- $2.8 \%$ 值を示し殆んど其の差を認めな ?.

\section{第 3 節 副腎摘出後皮質ホルモンによる代儅作用}

1) 両側副腎摘出倹，毎日 Cortisone $1.25 \mathrm{mg}$ 宛 4 回腹腔内に投与したる場合の朋蔵，腎臓，脾臓及び肺

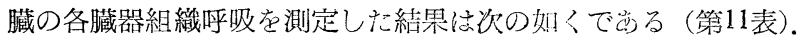

第11表 両側副腎摘出後 Cortisone 投与群に於ける諸臟器 Qo⿰

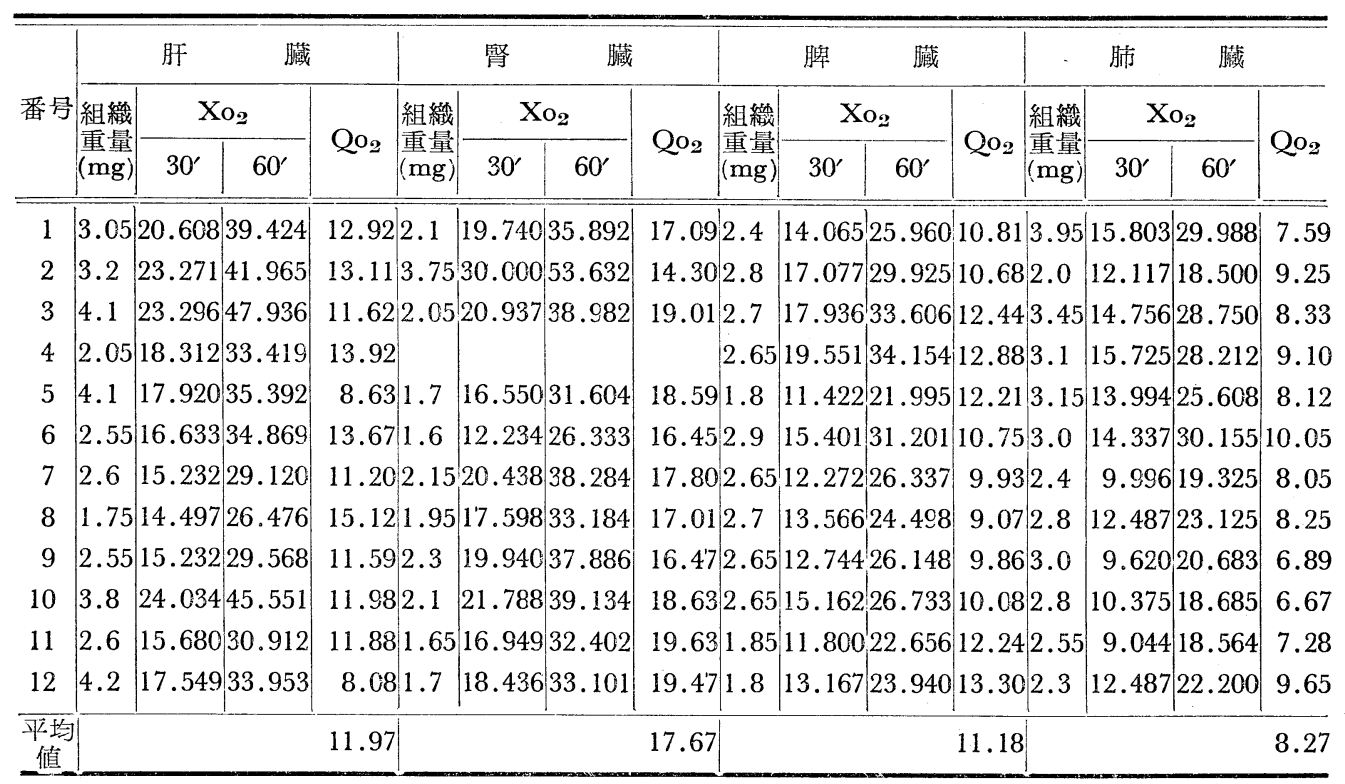

a) 䀒臟

Ringer 氏液中の肝藏組織呼吸に12例中最大値15.12，最小值8.08亿して平均值さ11.97で方る。

b）腎矌

Ringer 氏液中の腎臓組織呼吸は11例中最大值19.63，最小值14.30にして平均傎は17.67である。

c) 脾贜

Ringer 氏液中の脾㵴組織呼吸は12例中最大值13.30，最小值9.07亿して平均值は11.18である。

d) 肺臟

Ringer 氏液中の肺臟組織呼吸に12例中最大值10.05，最小值6.67亿して平均值は8.27である。

2）両側副腎摘出徐，毎日 DOCA $0.025 \mathrm{mg}$ 宛 4 回脊部皮下に投与したる場合の肝臟，緊㵴，脾臓及び肺 臓の各蔵器組織呼吸を測定した結果に次の如くである (第12表). 
第12表 雨側副腎摘出後 DOCA 投与群に於ける諸䁍器 $\mathrm{Qo}_{2}$

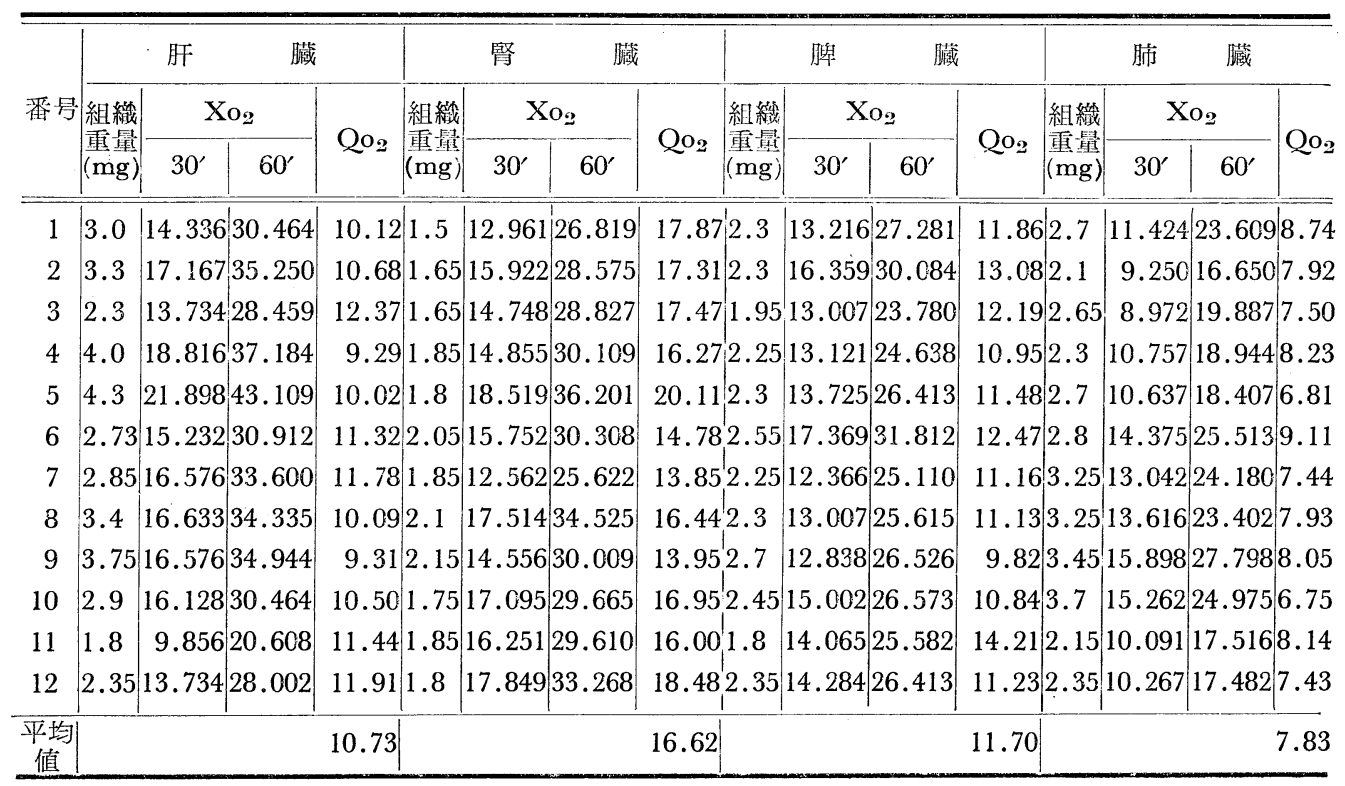

a) 肝臟

Ringer 氏液中の肝蔵組織呼吸は12例中最大值 12.37 ，最小值9.29亿して平均值は10.73である。

\section{b) 腎臟}

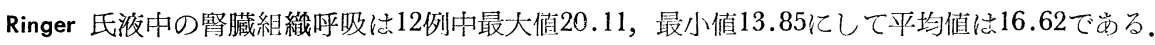

c) 脾㙎

Ringer 氏液中の脾蔵絕織呼吸は12例中最大值14.21，最小值9.82にして平均值は11.70である。

d) 肺䁃

Ringer 氏液中の脑蔵組織呼吸は12例中最大值 9.11 ，最小值 6.75 亿て平均值は7.83である。

3) 本節小括

雄性二十日鼠の両側副㛑摘出㷋 Cortisone 及び DOCA を投与せるもの>各臟器縕織呼吸を測定し, 次の 結果を得た (第13表).

第13表 両側副腎摘出後皮躓 Hormone 投与群の各藏器組織呼吸

\begin{tabular}{|c|c|c|c|c|c|c|c|c|c|}
\hline . & 例数 & 肝臟 & $\pm \%$ & 腎臟 & $\pm \%$ & 脾藏 & $\pm \%$ & 肺臓 & $\pm \%$ \\
\hline 対照手術群 & 10 & 12.10 & & 16.91 & & 11.38 & & 8.05 & \\
\hline 両側副腎摘出後 Cortisone 投与群 & 12 & 11.97 & $-1.0 \%$ & 17.67 & $+4.5 \%$ & 11.18 & $-1.7 \%$ & 8.27 & $+2.7 \%$ \\
\hline 両側副腎摘出後 DOCA 投与群 & 12 & 10.73 & $-11.3 \%$ & 16.62 & $-1.7 \%$ & 11.70 & $+2.8 \%$ & 7.83 & $-2.7 \%$ \\
\hline
\end{tabular}

a) 両側副腎摘出後 Cortisone 投与群の肝蔵組織呼吸の平均值は11.97亿して，対照值12.10との差を認め ない，同しく摘出後 DOCA 投与群の肝蔵組織呼吸の平均值は10.73にして，対照值に比して $11.3 \%$ 減弱 を認めた。

b) 両側副腎摘出後 Cortisone 投与群の腎蔵組織呼吸の平均值は17.67亿して，対照値16.91との間に特に 差を認めない，同じく摘出後 DOGA 投与群の腎臟組織呼吸の平均値は16.62亿して，対照值と殆んど差を 見ない? 


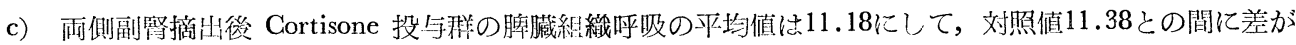
ない. 同じく摘出众 DOGA 投与群の脾藏組織呼吸の平均値は11.70にして, 対照值との間に差がない.

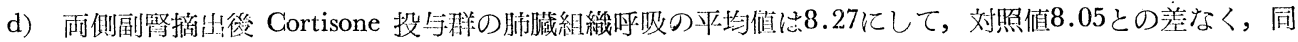

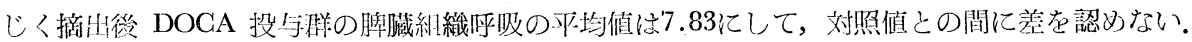

\section{第 4 節 副腎摘出動物の死亡率}

1) 雨侧副腎摘出後短期 間に於ける死亡率 （符14表）

雄性二十日鼠の雨側副腎 摘出後 4 日間の経過を峴察 したるに，摘出21例中，摘 出後第 1 日に死亡したるも の 3 例, 第 2 日に死亡した るもの 4 例, 第 3 日に死亡 したるもの 2 例，第 4 日に 死亡例なく，第4 日目末で の総計 9 例にして死亡率誌 42\%でらる。

2) 雨侧副等摘出唂Cortisone 存投与したる 場合の死亡率（第15 表)

両側副留摘出後, 毎日 Cortisone $1.25 \mathrm{mg}$ 宛 4 回腹 腔内に投与したる場合の死 亡率を検したるに，実験例 14例中，摘出後第 1 日に死 亡したるもの1例，第 2 日 に死亡したるもの 1 例, 計 2 例にして死亡率は14\%で 岕る。

3) 兩側副腎摘出後DOCA を投与してる場 合の死亡率(第16表) 両側副䇥摘出後, 毎日 DOCA $0.025 \mathrm{mg}$ 宛 4 回奉 部皮下に投与したる場合の 死亡率を検したるに，垁験 例20例中，摘出後第 1 日に 死亡したるもの 4 例，第 2 日に死亡したるもの 3 例, 第 3 日に死亡したるもの 1
第14表 両側副腎摘出群の死亡率

\begin{tabular}{|c|c|c|c|c|c|c|c|}
\hline \multirow{2}{*}{ 番 } & \multirow{2}{*}{ 摘出例数 } & \multicolumn{4}{|c|}{ 摘出後経過日数 } & \multirow{2}{*}{ 死亡数 } & \multirow{2}{*}{ 死亡率 } \\
\hline & & I & $\|$ & 1II & IV & & \\
\hline 1 & 4 & 1 & 0 & 1 & 0 & 2 & \\
\hline 2 & 3 & 0 & 1 & 0 & 0 & 1 & \\
\hline 3 & 3 & 1 & 0 & 0 & 0 & 1 & \\
\hline 4 & 3 & 0 & 1 & 0 & 0 & 1 & \\
\hline 5 & 3 & 1 & 0 & 0 & 0 & 1 & \\
\hline 6 & 2 & 0 & 1 & 0 & 0 & 1 & \\
\hline 7 & 1 & 0 & 1 & 0 & 0 & 1 & \\
\hline 8 & 2 & 0 & 0 & 1 & 0 & 1 & \\
\hline 計 & 21 & 3 & 4 & 2 & 0 & 9 & $42 \%$ \\
\hline
\end{tabular}

第15表 両側副腎摘出後 Cortisone 投与群の死亡率

\begin{tabular}{|c|c|c|c|c|c|c|c|}
\hline \multirow{2}{*}{ 番 } & \multirow{2}{*}{ 摘出例数 } & \multicolumn{4}{|c|}{ 摘出後経過日数 } & \multirow{2}{*}{ 死亡数 } & \multirow{2}{*}{ 死亡率 } \\
\hline & & I & II & III & IV & & \\
\hline 1 & 4 & 0 & 0 & 0 & 0 & 0 & \\
\hline 2 & 2 & 0 & 0 & 0 & 0 & 0 & \\
\hline 3 & 2 & 0 & 0 & 0 & 0 & 0 & \\
\hline 4 & 5 & 1 & 0 & 0 & 0 & 1 & \\
\hline 5 & 1 & 0 & 1 & 0 & 0 & 1 & \\
\hline 計 & 14 & 1 & 1 & 0 & 0 & 2 & $14 \%$ \\
\hline
\end{tabular}

第16䒾 両㑡副腎摘出後 DOCA 投与群の死亡率

\begin{tabular}{|c|c|c|c|c|c|c|c|}
\hline \multirow{2}{*}{ 番 号 } & \multirow{2}{*}{ 摘出例数 } & \multicolumn{4}{|c|}{ 摘出後経過日数 } & \multirow{2}{*}{ 死亡数 } & \multirow{2}{*}{ 死亡率 } \\
\hline & & I & II & III & IV & & \\
\hline 1 & 4 & 1 & 0 & 1 & 0 & 2 & \\
\hline 2 & 2 & 1 & 0 & 0 & 0 & 1 & \\
\hline 3 & 3 & 0 & 1 & 0 & 0 & 1 & \\
\hline 4 & 2 & 0 & 1 & 0 & 0 & 1 & \\
\hline 5 & 3 & 1 & 0 & 0 & 0 & 1 & \\
\hline 6 & 3 & 1 & 0 & 0 & 0 & 1 & \\
\hline 7 & 3 & 0 & 1 & 0 & 0 & 1 & \\
\hline 計 & 20 & 4 & 3 & 1 & 0 & 8 & $40 \%$ \\
\hline
\end{tabular}

第33巻 第 9 号 
例，計 8 例にして死亡率は $40 \%$ である。

4) 本節小括

雄性二十日鼠の両側副腎摘出後 4 日迄の死亡率虻，無処置群にては $42 \%$, 副腎摘出後 Cortisone 投与群に ては14\%，同じく DOCA 投与群にては40\%である。

\section{第3章 考按}

副腎摘出動物又结副腎機能不全時に於ける一般代謝機能即ち基礎代謝，含水炭素代謝，蛋白代謝，塩類代

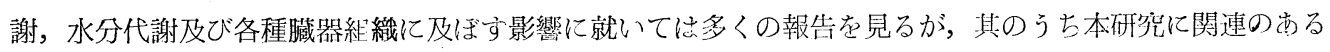
主なるものを求めてみよう。

Tripton2)（1940）副腎摘出白鼠の肝臓，腎臓，脳及び骨格笳の組織酸素消費量を検討した結果，脳历び骨

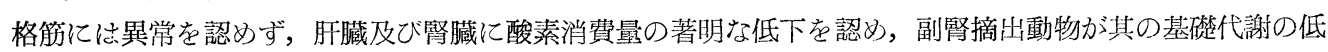
下を来すが，其の低下の原因は一般代謝機能の減弱によるよりも，或る物別な蔵器又心組織に於ける代謝障 碍の結果であると結論を下している。

Crismon \& Field ${ }^{32}$ (1940) 统副腎摘出白鼠に於ける脳，骨格筋及び腎㵶の酸素消費量を摘出手術後 4 日乃 至 8 日間に互り検索しだ結果，脳及び骨格筋に特に其の異常を認めないが，督㵴に於いては著明な呼吸の減 弱を認めている. Russel \& Wilhelmi ${ }^{4}$ (1940) 绾副腎摘出白鼠及び摘出動物に副腎皮質抽出物或いは DOC を

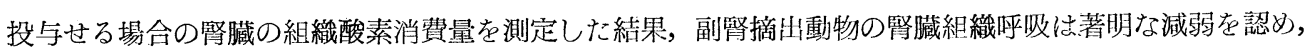
副腎皮質抽出物又は DOC の投与により対照動物の示す值に近づくか又は其れ以上の值を示す專を実験的に 立証している。文摘出動物に食塩を投与したる場合, 㹂臟に於ける酸素消費量の回復をも亦認めている.

副腎皮質機能不全が肝藏機能に及は要影響に就いての文献を検索するに，Wolf-Heidegger \& Waldmann $\mathbf{n}^{5)}$ (1942) は副筒摘出聄白鼠の旰臟に於けるVitamine C 含有量の著明な低下を認も，且つ其の際に Kupffer

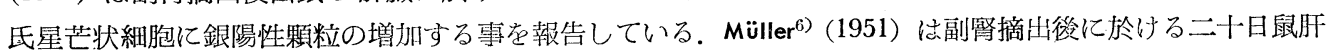
藏のKupffer 氏星芒状細胞に色素顆粒の生ずる事を報告し, 且つその腺細胞に特異な変化即ち紐胞の一部に Sudanschwarz positiv な二重屈折性の Lipoid の出現を認めた。秦）（1955）结猫の両側副腎摘出の場合に 於ける肝臟及び腎藏を組織学的に検索し，次の結果を得ている。即ち肝細胞の萎縮，腫大，軽度塤死，肝細

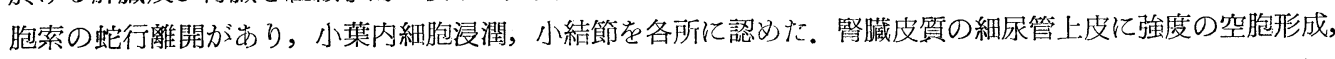
核の消失を認め，此の空胞は Lipoid 椂物質であると報告して居り，丸本等8) (1954) も副腎摘出動物に於 ける肝臟機能の多角的な障碍を認めている. Rowntree \& Snell9) (1931) 《 Addison 氏病患者に於いて B.S.P 排泄能力稍々低下している事を報告して居り, Thorn, Dorrance \& Day ${ }^{10)}$ (1942) は9 名の Addison 氏病患者 に馬尿酸合成試験を行い，全例に於いて肝臟機能の低下を認めている。鎮目11) (1955) 《副腎皮質障㥂時の 肝機能の低下は肝藏に於ける Glykogen の減少しているためであろうとなし，斯の如き場合 Vitamine G を投与すると肝臟に於ける Glykogen か增し肝蔵機能も改善すると述べている. Berman，Hoy \& Selye ${ }^{12)}$ (1947) 及び Friedgood, Vars \& Zerbe ${ }^{13)}$ (1950) 出副腎摘出動物に於いて朋藏の再生機能が減少しているが, 此れもVitamine C の投与により回復すると述べている.

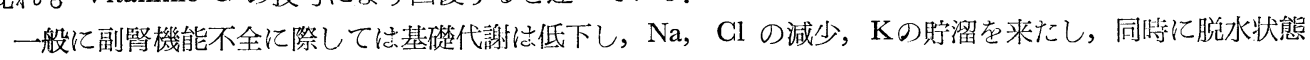

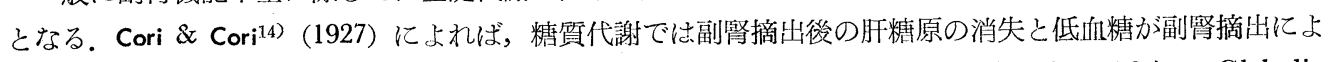
る第一次的の影響であるとしている。蛋白代謝仁就いて，Lewis ${ }^{15)}$ (1951) 《 Albumin の減少，r-Globulin の增加を報じ，White \& Rolf ${ }^{16)}$ (1947) によれば尿素 Clearance の減少による血中尿素及び NPN の増量と 尿中尿素の減少を来たすと報じている。脂質代謝では脂質 Ester 化障碍による脂肪吸収障碍と共に血中

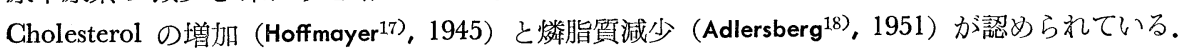

副腎皮質機能不全の場合，電解貿代謝異常のみならず，循環系の障碍が婜藏機能に異常を来たすべく，即 ち低血圧，血液の濃縮及び血液量の減少か慜臟機能を侵すと考えられる。Jiminez-Diaz ${ }^{19)}$ (1936), Russel \& Wilhelmi ${ }^{\mathbf{4}}$ (1940) も副腎摘出動物の腎臓に於ける $\mathrm{NH}_{3}$ 分泌機構の特異的な変化を考えて居り，此の変化は 
Cortisone 又心大悬の DOCA 投与により其の機能が泪に復すると述べている。 Lotspeich20)（1949）に上ると

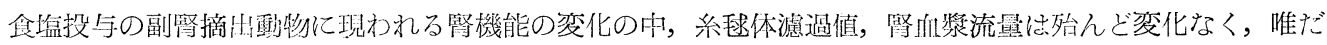

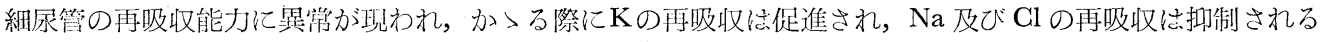

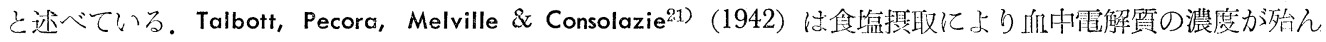

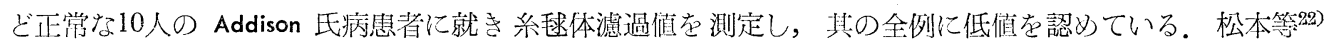

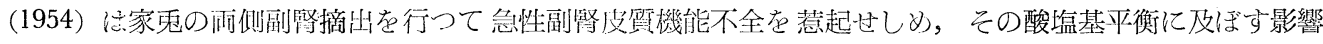

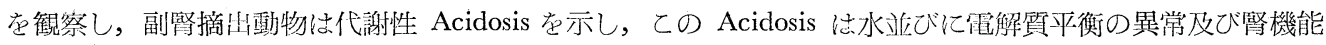
異常と悪循環在なすと報告している。 Loeb23)（1941）及び Roemmelt et al.24) (1949) 蚛副婜機能不全の際に 見られる堅臟機能障碍の最も重大なるもの〉一つとして，督藏の Na 排浽の俳限不能を指摘している，Guadino et al.25) (1949), Harrison et al.26) (1939), White et al.27) (1947) 结副㛑皮質機能障碍に際し，糸建体滤 過值の減少及び肾血漿流量の減少をむげて居り，Roberts \& Pitts ${ }^{28)}$ (1952) 䛱 DOC 及び Cortisone 共に副

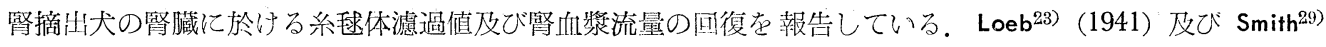

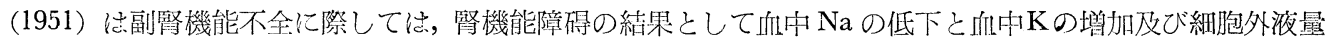
の減少を㟧げて居り，Barnett et al.30) (1949), Ferrebee et al.31) (1939)，Loeb³) (1941) 结副腎摘出動物及び

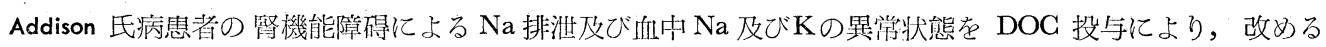
事が出来ると述べている，尚，腎臓䋖胞の代謝が副婜摘出後著しく変化する事は，酸素消贅量の測定により，

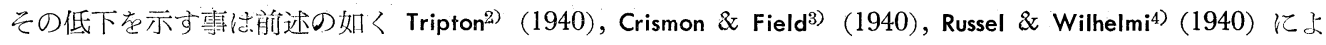
り報告妆られてい。。

根岸等32)（1953）は白鼠の副简摘出众 Cortisone 5mg 3 日間投与せる場合に於ける脾藏の 組織呼吸を測

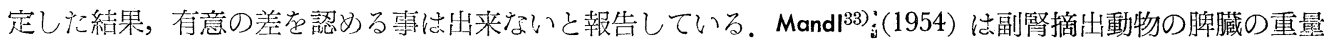
は，成熟及び未熟動物其に其の間に一致した影響はないと報告して居り，Cortisone を投与せる未熟動物の 脾藏重量は刘照に比して減少したと述べている。

Teppermann et al.34) (1943) 及び Miller ${ }^{35}$ ）(1950）によれば，多くの動物に於いては一側の副腎を摘出す ると他側は代償的に肥大を来たすと報告し，大樋36)（1956）によれば，一側副㛑摘出の場合，ACTH を介 して束状带の機能元准を起すほかに，下垂体を介せず直接に球状帯の機能六進を起すものなるを，その組織

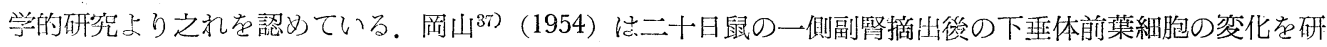
䋇し，30万至50日で其の変化の正常化を報告している。福原38（1952）《家鬼に於ける一側副腎摘出の際の 電解質代謝を検討し，血清 $\mathrm{Na}, \mathrm{Cl}$ は共に減少し， 2 日乃至 3 日目に最低值を示し，血清Kは 2 日目に最も

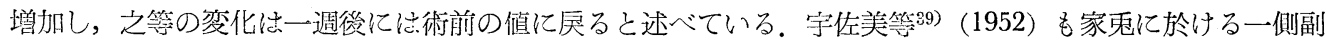

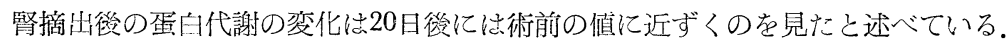

以上の文献の示す如く，一側副珡摘出動物に於いては時日の経過之共に其の機能の代償を認得るも，雨 側副腎摘出の際に於ける急性副腎機能不全に際してに, 特に肝藏及び腎臓に於いて，組織学的にも亦，機能 的にも種々の障碍を認めて居り，副腎皮質と肝臟及び腎藏が生体の正常の機能を維持するに重大な器官で㐫 る事より，其の関聯性《種々の方向より検討されつ〉西る。私の実験成績からみても，一側副腎摘出の際に

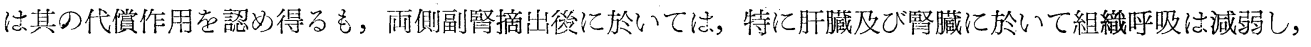
この際皮質 Hormone の投与により，Cortisone 及び DOCA 虻其の態度を異にするもの>，其の組織呼吸 の回復を認めるものである。

動物は副霜を摘出すると，漸次悪化する副婜脱落症状を呈し，多くは手術後 1 週間以内に死亡すると云わ

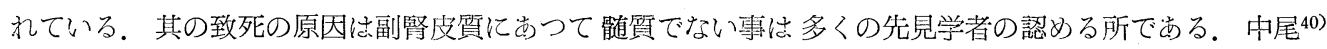
（1953）讼副筱摘出動物の生存期閒を決定する諸因子として，動物の種，系統，体重，性及び性週期，妊娠， 術前及び術後の動物の環境条件，手術手技及び完全摘出か子否か，麻醉薬の種類及び時閭，補副腎，季節の 10

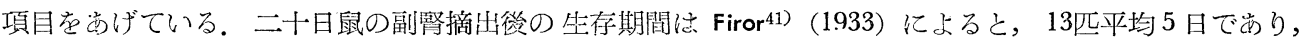
Bomskov42)（1935）によれば，幼弱二十日鼠174匹の中，164匹は 5 日迄に死亡し，手術後 7 日迄に全例の死亡 


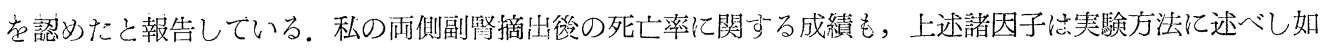
く, 可及的之れに注意を払いたるも, 諸藏器組織呼吸測定に際しての附随実験成績なるため, 摘出手術後 4 日目迄の死亡率統計によるもので学るが上述の成績とその規を一にする.

\section{第4音 結 論}

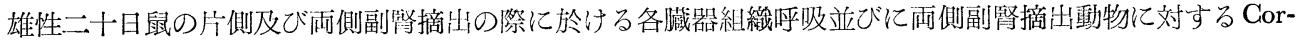
tisone 及び DOCA の代償作用に就いて検討した結果を要約すると，次の如くである。

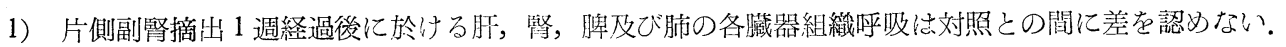

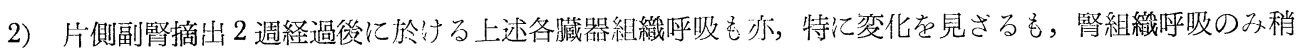
々減少の傾向を認めた。

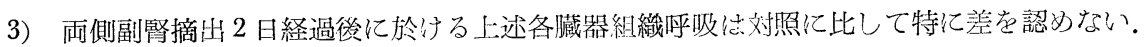

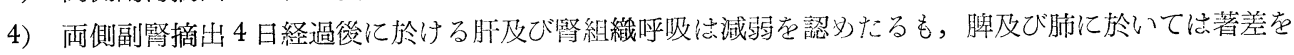
認めない。

5）両側副腎摘出後 Cortisone 在投与すると，乙れ等藏器組織の呼吸结回復の徵を示す。

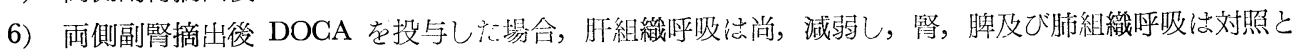
の間に差を認めない.

7) 両側副腎摘出後 4 日間の死亡率结42\%にして, 摘出後 Cortisone 投与群にては低率で市り, 摘出後 DOCA 投与群にては40\%にして，摘出後無処置群とDOCA 投与群との間に著差を認めない.

\section{第 2 篇 低温及び高温下に於ける副腎摘出の臓器 組織呼吸に及ぼす影響}

\section{第1章 実 験 方 法}

1）実験動物及び副腎摘出手術第 1 篇に於けると同じく，摘出及び対照手術共に麻酔法全く使用しなか つた。摘出動物には $1 \%$ 食塩水を投与した。

低温 Stress の方法として，実験には冬の低温期間を選び，温度測定伈飼育箱中に最高，最低寒暖計を入 れ，連日之れを記録し，時に保温を行いたるも実験期間を通じ $2 \sim 10^{\circ} \mathrm{G}$ 範囲内に於いて飼育した。

高温 Stress の方法として结，大型邲卵器の一部を開放し，中に飼育箱を入れ，温度測定は前同様となし， $36 \sim 38^{\circ} \mathrm{C}$ 範囲に於いて飼育し，湿度は約 $63 \%$ とした。

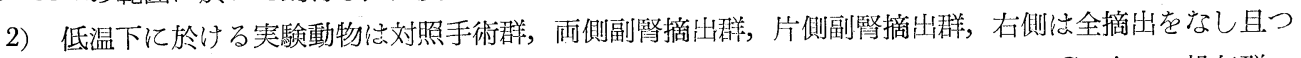

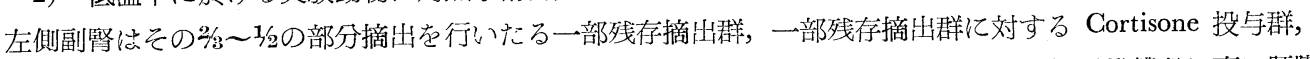
同じく DOCA 投与群及び ACTH 投与群の 7 群に分ち, 各群共に副腎摘出 4 ～ 5 日経過後撲殺し直に朋藏 及び腎臟を取り出し実験に供した。

Cortisone 副筹摘出後, 毎日 $1.25 \mathrm{mg}$ 宛 4 回腹腔内に注入し, DOCA 法毎日 $0.05 \mathrm{mg}$ 宛 4 回脊部皮下に注 射した。副腎皮質刺战 Hormone としては ACTH（シオノギ）を毎日 $0.5 \mathrm{mg}$ 宛 4 回腹腔内に注射した。

3) 高温下に於ける実験動物结対照手術群，一部残存摘出群，两側副腎摘出群，同群に対する Cortisone 投与群及び DOCA 投与群の 5 群に分ち, 各群共亿前同様実験に供した。

4) 組織呼吸測定は第 1 篇に於けると同じ方法によつた。

\section{第 2 章 実 験 成 績 第 1 節 低溫下に於ける副腎摘出実験}

1) 対照手術後 $2 \sim 10^{\circ} \mathrm{C} の$ 低温下に於いて 4〜5 日経過せるもの>肝藏及び㹂臟組織呼吸を測定した結果 
第17表 副腎摘出対照手術群（低温）に於ける肝藏及び腎藏の $\mathrm{Qo}_{2}$

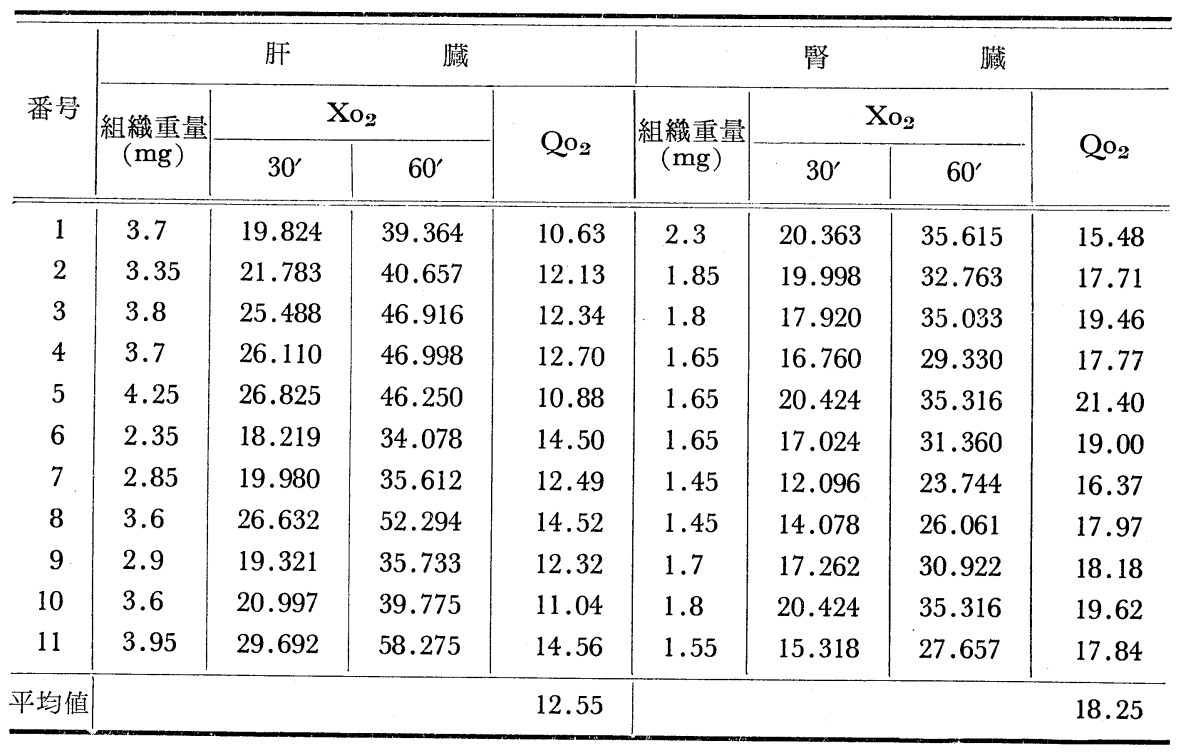

は次の如くである(第1'7表).

\section{a) 肝臟}

Ringer 氏液中の肝藏組織呼吸は11例中最大值14.56, 最小值10.63にして平均値は12.55である。

\section{b）留䑋}

Ringer 氏液中の婜臟組織呼吸は11例中最大值 21.40 , 最小值 15.48 亿て平均值は18.25でらる。

2）両側副腎摘出後，低温下に扣きたるものは 4 例実験に供したるも全例翌日死亡した。

3) 片側副腎摘出後, 低温下に於いて 4 5 日経過せるもの>肝蔵及び腎臟組織呼吸を測定した結果は次 の如くである (第18表).

第18表 片側副简摘出群（低温）に於ける肝臟及び腎藏のQo⿰

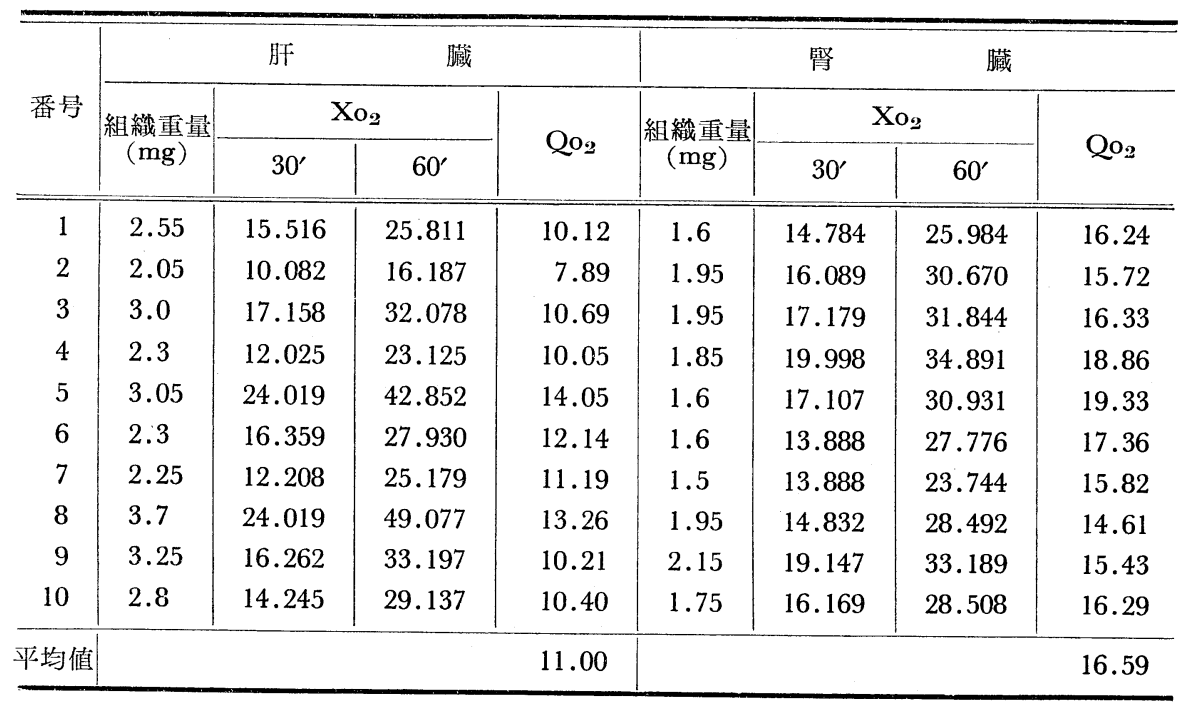




\section{a) 肝䁍}

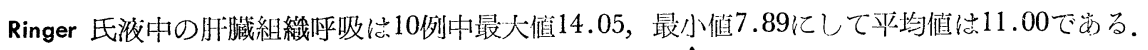

\section{b）腎臟}

Ringer 氏液中の掔蔵組織呼吸は10例中最大值19.33，最小值14.61にして平均值は16.59である。

4) 一部副婜残存摘出倹，低温下に於いて 4〜5 日経過热るもの>肝臓及び腎㵴組織呼吸を測定した結果 は次の如くである(第19表)。

第19表 一部副腎残存摘出群（低温）に於ける肺瀻及び腎㶓の $\mathrm{QO}_{2}$

\begin{tabular}{|c|c|c|c|c|c|c|c|c|}
\hline \multirow{3}{*}{ 番号 } & \multicolumn{4}{|c|}{ 肝 } & \multicolumn{4}{|c|}{ 藏 } \\
\hline & \multirow{2}{*}{$\begin{array}{c}\text { 組織重量 } \\
\text { (mg) }\end{array}$} & \multicolumn{2}{|c|}{$\mathrm{Xo}_{2}$} & \multirow{2}{*}{$\mathrm{Qo}_{2}$} & \multirow{2}{*}{$\begin{array}{c}\text { 組緇重量 } \\
(\mathrm{mg})\end{array}$} & \multicolumn{2}{|c|}{$\mathrm{Xo}_{2}$} & \multirow{2}{*}{$\mathrm{QO}_{2}$} \\
\hline & & $30^{\prime}$ & $60^{\prime}$ & & & $30^{\prime}$ & $60^{\prime}$ & \\
\hline 1 & 2.3 & 11.422 & 19.446 & 8.45 & 1.55 & 16.576 & 30.016 & 19.36 \\
\hline 2 & 2.85 & 14.472 & 23.797 & 8.34 & 1.8 & 20.447 & 35.531 & 19.73 \\
\hline 3 & 2.65 & 13.875 & 23.587 & 8.90 & 1.7 & 20.424 & 35.742 & 21.02 \\
\hline 4 & 2.75 & 15.481 & 33.984 & 12.35 & 1.65 & 13.883 & 29.568 & 17.92 \\
\hline 5 & 2.25 & 13.502 & 26.110 & 11.60 & 1.3 & 12.234 & 23.045 & 17.72 \\
\hline 6 & 3.35 & 22.200 & 41.625 & 12.42 & 1.55 & 16.169 & 27.657 & 17.84 \\
\hline 7 & 3.7 & 23.505 & 48.144 & 13.01 & 1.55 & 12.096 & 23.296 & 15.02 \\
\hline 8 & 2.45 & 13.950 & 29.467 & 12.02 & 1.8 & 13.240 & 27.235 & 15.13 \\
\hline 9 & 4.3 & 22.292 & 46.250 & 10.75 & 2.0 & 15.743 & 31.912 & 15.95 \\
\hline 10 & 2.65 & 11.328 & 20.201 & 7.62 & 1.55 & 12.096 & 22.400 & 14.45 \\
\hline 11 & 2.6 & 10.444 & 19.545 & 7.51 & 2.0 & 16.341 & 28.324 & 14.16 \\
\hline 12 & 3.05 & 16.187 & 29.692 & 9.73 & 1.55 & 14.467 & 23.828 & 15.37 \\
\hline 平均值 & & & & 10.24 & & & & 16.97 \\
\hline
\end{tabular}

\section{a) 䀒眫}

Ringer 氏液中の肝藏組織呼吸は12例中最大值13.01，最小值7.51にして平均值は10.24である。

\section{d）㹂頉}

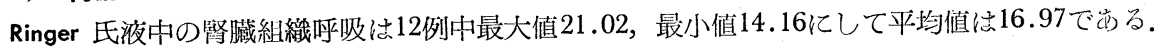

5）低温下に於いて，一部副督残存摘出後 ACTH を毎日 $0.5 \mathrm{mg}$ 宛 4 回，腹腔内に注射せる場合の朋㖪及

第20表 一部副霜残存摘出後 ACTH 投与群（低温）に於ける肝藏及び㹂藏の Qo 2

\begin{tabular}{|c|c|c|c|c|c|c|c|c|}
\hline \multirow{3}{*}{ 番号 } & \multicolumn{4}{|c|}{ 肝 } & \multicolumn{4}{|c|}{ 腎 } \\
\hline & \multirow{2}{*}{ 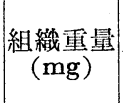 } & \multicolumn{2}{|c|}{$\mathrm{Xo}_{2}$} & \multirow{2}{*}{$\mathrm{Qo}_{2}$} & \multirow{2}{*}{$\begin{array}{c}\text { 組織重量 } \\
(\mathrm{mg})\end{array}$} & \multicolumn{2}{|c|}{$\mathrm{Xo}_{2}$} & \multirow{2}{*}{$\mathrm{QO}_{2}$} \\
\hline & & $30^{\prime}$ & $60^{\prime}$ & & & $30^{\prime}$ & $60^{\prime}$ & \\
\hline 1 & 2.55 & 16.425 & 28.697 & 11.25 & 1.55 & 14.784 & 26.880 & 17.34 \\
\hline 2 & 2.85 & 18.426 & 35.957 & 12.61 & 1.65 & 15.335 & 29.581 & 17.92 \\
\hline 3 & 2.45 & 17.205 & 34.780 & 14.19 & 1.65 & 18.296 & 33.614 & 20.37 \\
\hline 4 & & & & & 1.45 & 13.888 & 27.328 & 18.84 \\
\hline 5 & 2.9 & 17.904 & 33.197 & 11.44 & 1.35 & 13.408 & 22.626 & 16.76 \\
\hline 6 & 3.6 & 23.587 & 45.325 & 12.59 & 1.5 & 14.467 & 25.530 & 17.02 \\
\hline 平均値 & & & & 12.41 & & & & 18.04 \\
\hline
\end{tabular}


び腎臟組織呼吸を測定した結果は次の如くである (第20表).

\section{a) 旰贜}

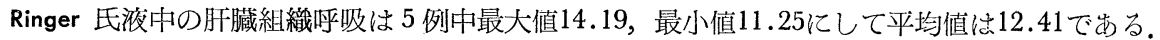

\section{b) 腎臟}

Ringer 氏液中の腎藏組織呼吸は 6 例中最大值 20.37 ，最小値16.76亿して平均值は18.04である。

6）低温下に於いて，一部副繁残存摘出後 Cortisone を毎日 $1.25 \mathrm{mg}$ 宛 4 回，腹腔内に注射せる場合の肝 㵴及び㹂藏組織呼吸を測定した結果は次の如くである（第21表）。

第21表 一部副腎残存摘出後 Cortisone 投与群（低温）に於ける肝臟及び腎臟の Qo 2

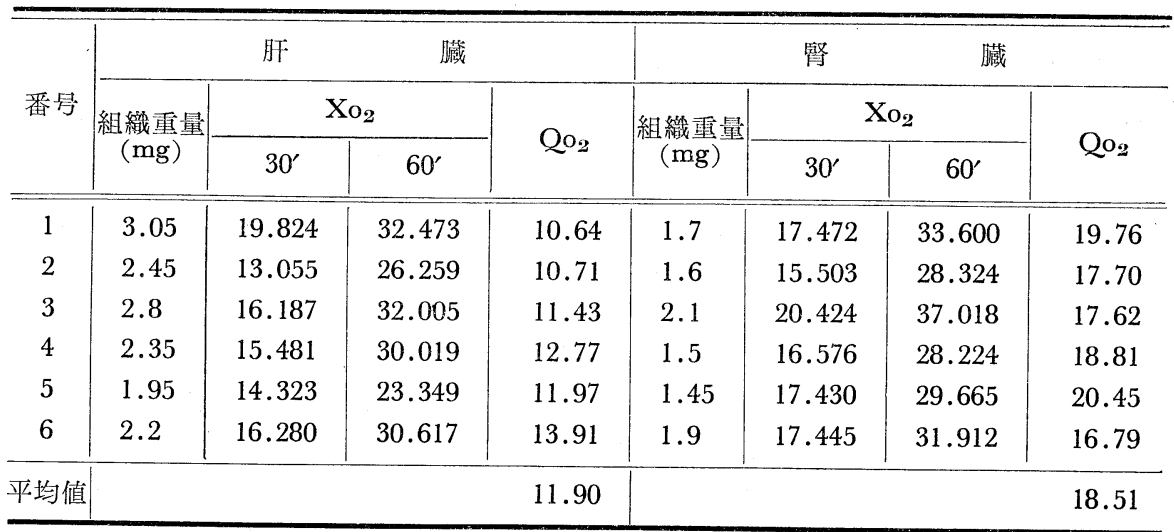

\section{a) 䀒贜}

Ringer 氏液中の肝藏組織呼吸は 6 例中最大值13.91，最小值10.64亿して平均值は11.90でらる。

\section{b）腎壐}

Ringer 氏液中の腎臟組織呼吸は 6 例中最大値20.45，最小值16.79にして平均值は18.51である。

7）低温下に於いて，一部副筲残存摘出後 DOCA を毎日 $0.05 \mathrm{mg}$ 宛 4 回，脊部皮下に注射した場合の肝 臟及び腎蔵組織呼吸を測定した結果は次の如くである(第22表).

第22表 一部副腎残存摘出後 DOCA 投与群（低温）に於ける朋臟及び腎蔵の $\mathrm{Qo}_{2}$

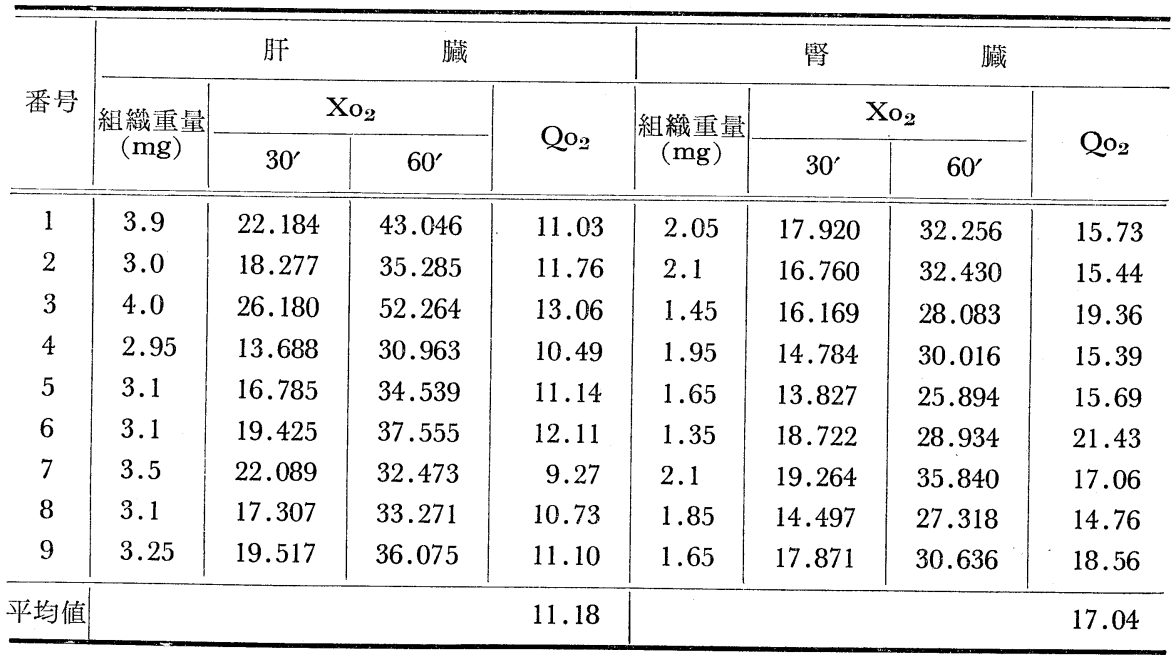




\section{a) 自千睵}

Ringer 氏液中の肝藏組織呼吸仙 9 例中最大值 13.06 , 最小值9.27亿して平均值は11.18である。

\section{b）腎裁}

Ringer 氏液中の婜藏組織呼吸住 9 例中最大值 21.43 , 最小值 14.76 亿して平均值は 17.04 である。

8) 本節小括

低温下 $\left(2 \sim 10^{\circ} \mathrm{C}\right)$ に於ける副腎摘出及び摘出動物に ACTH, Cortisone 及び DOCA を投与せる場合の 肝藏及び腎藏組織呼吸を測定した結果を要約して，次の成績を得た（第 23 表）。

第23表 低温下に於ける副謷摘出及び摘出動物に ACTH, Cortisone 及び DOCA 投与群の組織呼吸

\begin{tabular}{|c|c|c|c|c|c|}
\hline & 例数 & 肝 㶓 & \pm & 腎 臓 & \pm \\
\hline 対照手術群 & 11 & 12.55 & & 18.25 & \\
\hline 片側副婜摘出群 & 10 & 11.00 & $-12.3 \%$ & 16.59 & $-9.0 \%$ \\
\hline 一部副粲残存摘出群 & 12 & 10.24 & $-18.4 \%$ & 16.97 & $-7.0 \%$ \\
\hline 同上摘出後 $\mathrm{ACTH}$ 投与群 & 6 & 12.41 & $-1.1 \%$ & 18.04 & $-1.1 \%$ \\
\hline 同上摘出後 Cortisone 投与群 & 6 & 11.90 & $-5.1 \%$ & 18.51 & $+1.4 \%$ \\
\hline 同上摘出後 DOCA 投与群 & 9 & 11.18 & $-10.9 \%$ & 17.04 & $-6.6 \%$ \\
\hline
\end{tabular}

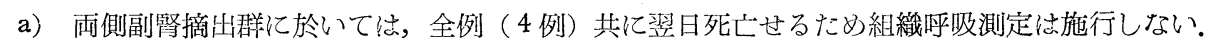

b) 片側副腎摘出群に於いて，肝藏組織呼吸は対照に比して12.3\%減弱し，腎臓組織呼吸も亦，9\%減弱 の傾问を示している.

c）一部副腎残存摘出群の肝藏組織呼吸は対照に比して $18.4 \%$ 減弱し，婜藏組織呼吸も亦，7\%減弱の傾 向を示す.

d) 一部副腎残存摘出㷋 ACTH を0.5mg宛 4 回，腹腔内注射群の肝蔵及び腎臓組織呼吸ほ対照と殆んど 差を見ない.

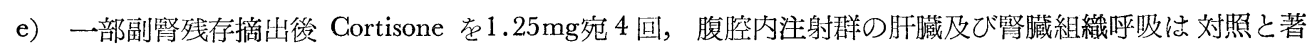
差を認めない.

f) 一部副腎残存摘出後 DOGA を0.05mg宛 4 回，皮下注射群の肝臓組織呼吸は10.9\%娍弱し，更に腎 藏組織呼吸も亦, $6.6 \%$ 減弱の傾向を示す。

\section{第 2 節 高溫下に於ける㓢腎摘出実験}

1) 対照手術後 $36 〜 38^{\circ} \mathrm{C}$ 高温下に於いて，4〜5 日経過将るもの>肝蔵及び腎臟組織呼吸を測定した結 果虻次の如くである (第24表).

第24表 副腎摘出対照手術群（高温）に於ける肝蔵及び腎藏のQo.2

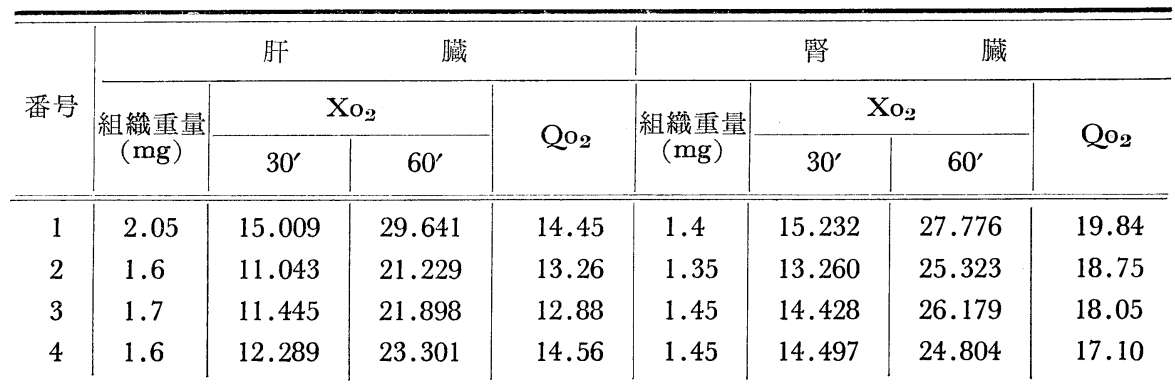




\begin{tabular}{r|l|l|l|l|l|l|l|l}
5 & 2.0 & 12.085 & 20.589 & 10.29 & 1.3 & 14.467 & 25.530 & 19.63 \\
6 & 2.1 & 15.355 & 28.675 & 13.65 & 1.85 & 19.147 & 34.040 & 18.40 \\
7 & 2.3 & 13.962 & 25.179 & 10.94 & 2.05 & 17.248 & 34.097 & 16.63 \\
8 & 2.75 & 15.880 & 28.807 & 10.47 & 1.95 & 19.008 & 35.251 & 18.07 \\
9 & 3.3 & 19.545 & 35.285 & 10.69 & 1.55 & 13.440 & 26.880 & 17.34 \\
10 & 2.3 & 15.632 & 27.195 & 11.82 & 1.9 & 17.262 & 31.592 & 16.62 \\
\hline 平均值 & & & & & & & & 18.04 \\
\hline
\end{tabular}

\section{a) 䀒贜}

Ringer 氏液中の肝蔵組織呼吸は10例中最大值14.56，最小值10.29にして平均值は12.30である。

\section{b）腎矌}

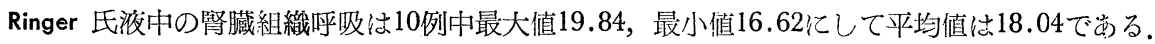

2) 高温下に於いて，一部副堅残存摘出後 $4 \sim 5$ 日経過せるもの>肝蔵及び腎藏組織呼吸を測定した結果 は次の如くでのる(第25表).

第25表 一部副粲残存摘出群 (高温) に於ける肝臟及び腎藏のQo.

\begin{tabular}{|c|c|c|c|c|c|c|c|c|}
\hline \multirow{3}{*}{ 番号 } & \multicolumn{4}{|c|}{ 肝 } & \multicolumn{4}{|c|}{ 腎 } \\
\hline & \multirow{2}{*}{$\begin{array}{c}\text { 組織重量 } \\
(\mathrm{mg})\end{array}$} & \multicolumn{2}{|c|}{$\mathrm{Xo}_{2}$} & \multirow{2}{*}{$\mathrm{Qo}_{2}$} & \multirow{2}{*}{$\begin{array}{c}\text { 組綫重量 } \\
(\mathrm{mg})\end{array}$} & \multicolumn{2}{|c|}{$\mathrm{Xo}_{2}$} & \multirow{2}{*}{$\mathrm{Qo}_{2}$} \\
\hline & & $30^{\prime}$ & $60^{\prime}$ & & & $30^{\prime}$ & $60^{\circ}$ & \\
\hline 1 & 2.65 & 16.337 & 32.078 & 12.10 & 1.6 & 14.748 & 28.492 & 17.80 \\
\hline 2 & 2.25 & 12.672 & 25.900 & 11.51 & 1.5 & 13.440 & 25.984 & 17.32 \\
\hline 3 & 2.6 & 16.938 & 31.054 & 11.94 & 1.85 & 17.262 & 30.670 & 16.57 \\
\hline 4 & 2.65 & 12.383 & 22.454 & 8.47 & 1.9 & 19.998 & 35.316 & 18.58 \\
\hline 5 & 4.25 & 21.275 & 39.312 & 9.25 & 1.65 & 17.598 & 30.838 & 18.68 \\
\hline 6 & 2.05 & 13.875 & 24.142 & 11.77 & 1.4 & 10.558 & 18.519 & 13.22 \\
\hline 7 & 3.0 & 11.562 & 22.662 & 7.55 & 2.05 & 16.592 & 30.168 & 14.71 \\
\hline 8 & 2.65 & 13.042 & 24.975 & 9.42 & & & & \\
\hline 平均值 & & & & 10.25 & & & & 16.69 \\
\hline
\end{tabular}

\section{a) 䀒欗}

Ringer 氏液中の肝臟組織呼吸は 8 例中最大便 12.10 , 最小値7.55にして平均値は10.25である。

\section{b）腎瀻}

Ringer 氏液中の䉰藏組織呼吸は7 例中最大值18.68，最小值13.22亿して平均值は16.69である。

3) 高温下に於いて，両側副腎摘出後 4 ～ 5 日経過せるもの>肝藏及び腎藏組織呼吸を測定した結果は次 の如くで西る (第26表).

\section{a) 肝㙎}

Ringer 氏液中の肝蔵組織呼吸は 9 例中最大值 10.67 ，最小值6.35亿して平均值は8.76である。

\section{b）婜臟}

Ringer 氏液中の腎藏組織呼吸は 9 例中最大值17.28，最小値14.16亿して平均值は15.68である。

4) 高温下に於いて，両側副腎摘出後 Cortisone を毎日1.25mg宛 4 回，腹腔内に注射した場合の朋臓及 び睯藏組織呼吸を測定した結果は次の如くである (第27表). 


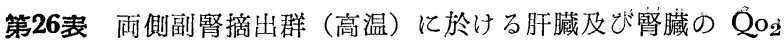

\begin{tabular}{|c|c|c|c|c|c|c|c|c|}
\hline \multirow{3}{*}{ 番号 } & \multicolumn{2}{|r|}{ 肝 } & \multicolumn{2}{|c|}{ 藏 } & \multicolumn{4}{|c|}{ 警 } \\
\hline & \multirow{2}{*}{$\begin{array}{c}\text { 組繊重量 } \\
(\mathrm{mg})\end{array}$} & \multicolumn{2}{|c|}{$\mathrm{Xo}_{2}$} & \multirow{2}{*}{$\mathrm{QO}_{2}$} & \multirow{2}{*}{$\begin{array}{c}\text { 組織重量 } \\
(\mathrm{mg})\end{array}$} & \multicolumn{2}{|c|}{$\mathrm{Xo}_{3}$} & \multirow{2}{*}{$\mathrm{Qo}_{2}$} \\
\hline & & $30^{\prime}$ & $60^{\prime}$ & & & $30^{\prime}$ & $60^{\prime}$ & \\
\hline 1 & 2.6 & 13.688 & 24.072 & 9.25 & 1.55 & 12.544 & 21.952 & 14.16 \\
\hline 2 & 2.0 & 9.325 & 14.174 & 7.08 & 1.6 & 13.827 & 23.045 & 14.40 \\
\hline 3 & 2.2 & 12.487 & 20.350 & 9.25 & 1.8 & 17.445 & 27.657 & 15.36 \\
\hline 4 & 2.6 & 11.422 & 19.068 & 7.33 & 1.4 & 11.648 & 20.608 & 14.72 \\
\hline 5 & 2.1 & 12.234 & 18.053 & 8.59 & 1.5 & 15.000 & 24.804 & 16.53 \\
\hline 6 & 1.95 & 7.400 & 12.395 & 6.35 & 1.6 & 17.445 & 27.657 & 17.28 \\
\hline 7 & 3.35 & 18.880 & 35.777 & 10.67 & 1.9 & 16.128 & 29.120 & 15.32 \\
\hline 8 & 3.15 & 17.531 & 32.600 & 10.34 & 1.55 & 15.503 & 25.810 & 16.65 \\
\hline 9 & 3.55 & 18.962 & 34.780 & 9.79 & 1.7 & 17.020 & 28.508 & 16.76 \\
\hline 平均値 & & & & 8.76 & & & & 15.68 \\
\hline
\end{tabular}

第27䒾 两側副腎摘出後 Cortisone 投与群（高温）に於ける肝藏及び㹂藏のQo 2

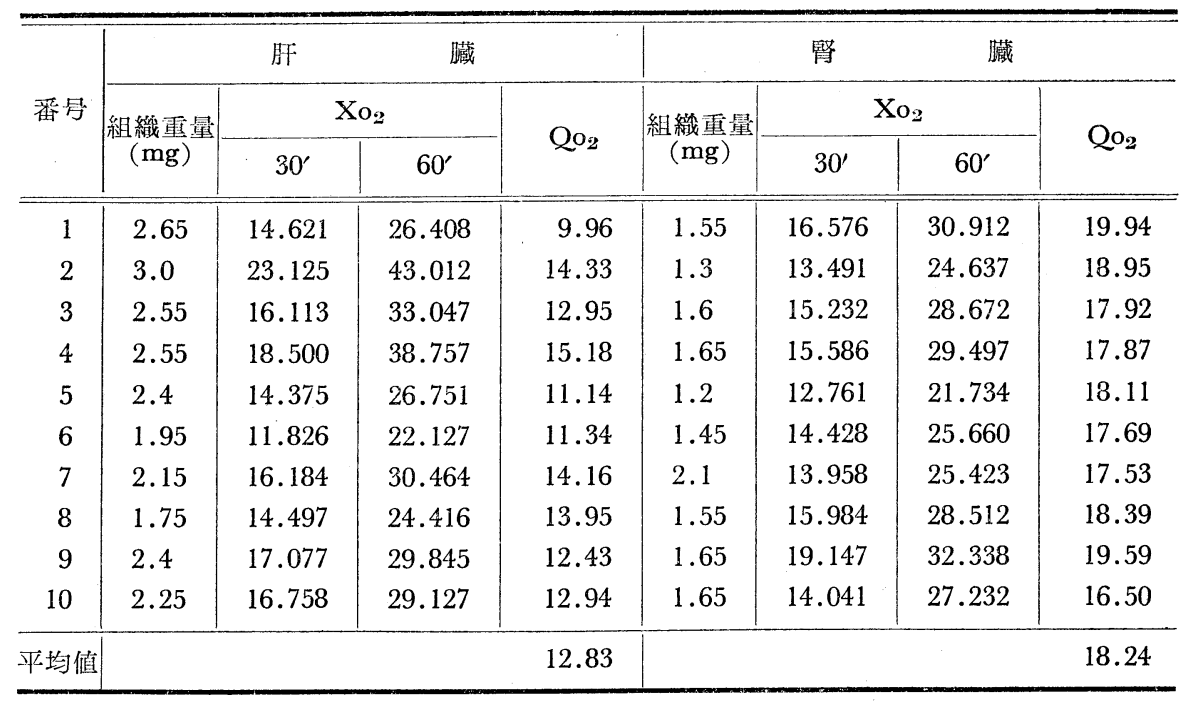

\section{a) 旰脿}

Ringer 氏液中の肝藏組織呼吸は10例中最大値15.18，最小値9.96亿して平均值は12.83である。

\section{b）腎䁍}

Ringer 氏液中の婜臟組䋊呼吸は10例中最大值19.94，最小値16.50にして平均值は18.24である。

5）高温下に於いて，両側副督摘出兴 DOCA を毎日 $0.05 \mathrm{mg}$ 宛 4 回，脊部皮下に注射した場合の肝藏及 び婜藏組織呼吸を測定した結果は次の如くである (第28表).

a) 肝臟

Ringer 氏液中の肝藏組織呼吸仙10例中最大值 12.94 ，最小值 9.72 そして平均值は11.28である。

\section{b）緊臟}

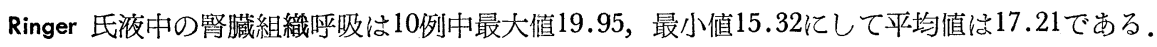




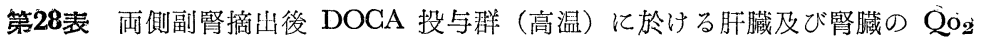

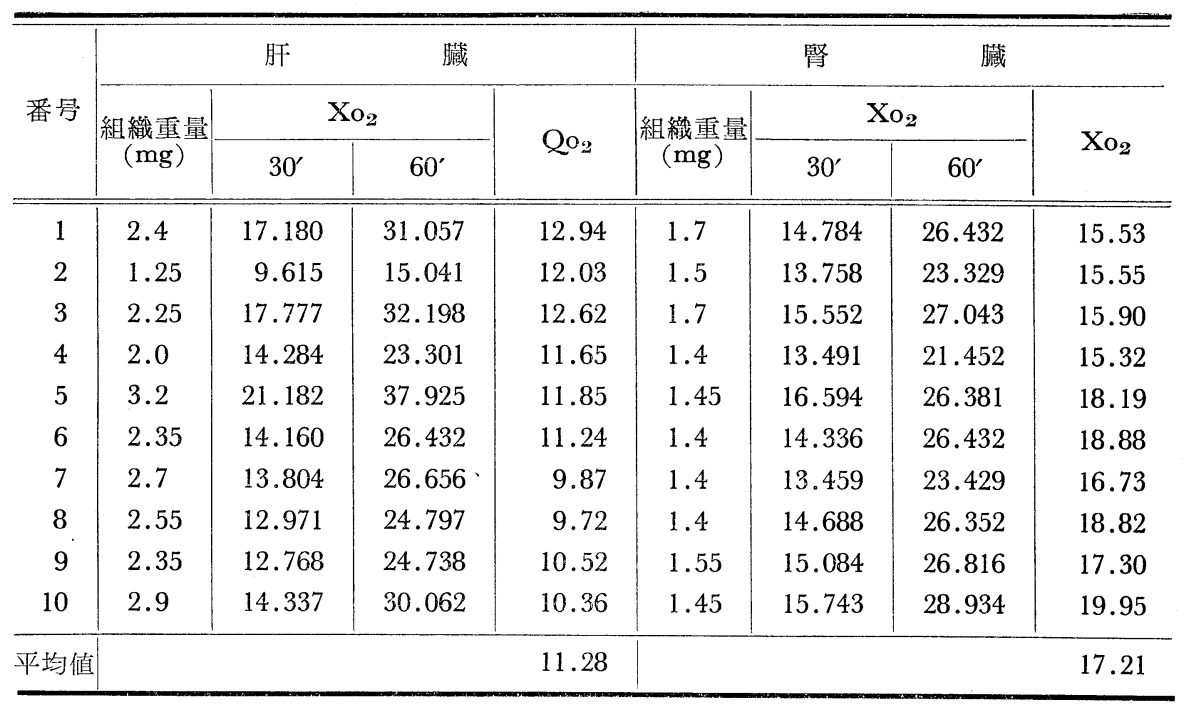

6) 本節小括

高温下 $\left(36 \sim 38^{\circ} \mathrm{C}\right)$ に於ける副腎摘出及び摘出動物に Cortisone 及び DOCA を注射せる場合の朋臟及び 㷫藏組織呼吸を測定したる結果を要約して，次の成績を得た (第29表).

第29表 高温下に於ける副霄摘出及び摘出動物に Cortisone 及び DOGA 投与群の組織呼吸

\begin{tabular}{|c|c|c|c|c|c|}
\hline & 例数 & 肝 笘 & $\pm \quad \%$ & 腎 臟 & \pm \\
\hline 対照手術群 & 10 & 12.30 & & 18.04 & \\
\hline 一部副腎残存摘出群 & 8 & 10.25 & $-16.6 \%$ & 16.69 & $-7.4 \%$ \\
\hline 両侧副腎摘泏群 & 9 & 8.76 & $-28.7 \%$ & 15.68 & $-13.0 \%$ \\
\hline 雨側副粲摘出後 Cortisone 投与群 & 10 & 12.83 & $+4.3 \%$ & 18.24 & $+1.1 \%$ \\
\hline 両側副腎摘出後 DOCA 投与群 & 10 & 11.28 & $-8.2 \%$ & 17.21 & $-4.6 \%$ \\
\hline
\end{tabular}

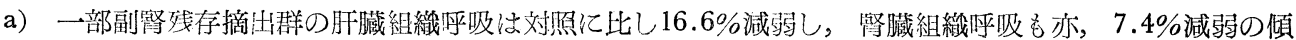
向を示す.

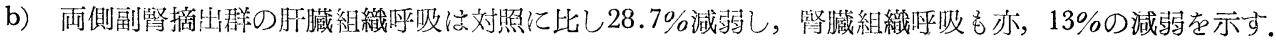

c）両側副腎摘出後，毎日 Cortisone を1.25mg宛 4 回，腹腔内注射群の肝臟及び腎蔵組織呼吸は対照之 の閪に差を認めない.

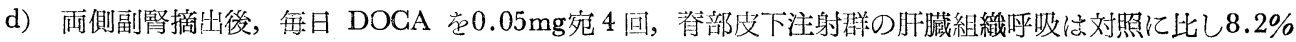
減少を認めたるも，腎臓組織呼吸は対照との間に差を認めない。

\section{第 3 節 低溫及び高溫下に於ける副腎摘出動物の死亡率}

1）低温下に於ける副腎摘出動物の死亡率に及ばす ACTH, Cortisone 及び DOCA の影響（第30表）

低温下 $\left(2 \sim 10^{\circ} \mathrm{C}\right)$ に於ける两側副婜摘出 4 例は，全例共に摘出翌日に死亡，即ち $100 \% の$ 死亡率を示し た. 片側副腎摘出13例中，死亡せるもの 3 例にして $23 \% の$ 死亡率を示し，一部副腎残存摘出25例中，死亡せ るもの13例にして死亡率は52\%で岕る。之の一部副繁残存摘出群に効する ACTH 投与群の死亡率は14\%, Cortisone 投与群は $0 \%$, DOCA 投与群は30\%である. 
第30表 低温下に於ける副腎摘出動物の死亡率

\begin{tabular}{|c|c|c|c|}
\hline & 実験例 & |死亡例 & 死亡率 \\
\hline 両側副腎摘出群 & 4 & 4 & $100 \%$ \\
\hline 片側副㛑摘出群 & 13 & 3 & $23 \%$ \\
\hline 一部副腎残存摘出群 & 25 & 13 & $52 \%$ \\
\hline 同上摘出後 ACTH 投与群 & 7 & 1 & $14 \%$ \\
\hline 同上摘出後 Cortisone 投与群 & 6 & 0 & $0 \%$ \\
\hline 同上摘出後 DOCA 投与群 & 13 & 4 & $30 \%$ \\
\hline
\end{tabular}

第31表 高温下に於ける副腎摘出動物の死亡率

\begin{tabular}{l|r|r|r}
\hline & 実験例|死亡例 & 死亡率 \\
\hline \hline 一部副腎残存摘出群 & 16 & 8 & $50 \%$ \\
両側副篎摘出群 $\left(40^{\circ} \mathrm{C}\right)$ & 8 & 8 & $100 \%$ \\
両側副腎摘出群 $\left(36 \sim 38^{\circ} \mathrm{C}\right)$ & 20 & 11 & $55 \%$ \\
同上摘出後 Cortisone 投与群 & 10 & 0 & $0 \%$ \\
同上摘出後 DOCA 投与群 & 20 & 10 & $50 \%$ \\
\hline
\end{tabular}

2)高温下に於ける副腎摘出動物の死亡率 に队ぼす Cortisone 及び DOCA の影 響（第31表）

䯩温下 $\left(36 \sim 38^{\circ} \mathrm{C}\right)$ 亿於ける一部副腎残存 摘出16例中，8例の死亡を認め，50\%の死亡 率在示方. 雨侧副繁摘出20例中，11例の死亡 尼来し，55\%の死亡率を示し， $40^{\circ} \mathrm{C}$ 高温に ては两侧摘此8例行いたるも，全例共に翌日 死亡した。栭侧副婜摘出㷋 Cortisone 投与群 驻10例を用い笑験を行いたるに，死亡例なく， DOCA 投与扸さ50\%の死亡率を示した。

3) 本節小括

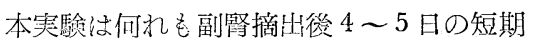
間钼察であるが，刘照実験例には死亡例なく，

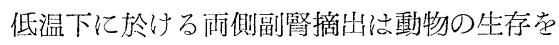
極めて短縮せしめ，一部副婜残存摘出群に於 いて死亡率结 Cortisone, ACTH 及び DOCA 投与群の順に, 減弱してくる.

高温下に於ける両側副腎摘出群の死亡率《 Cortisone の投与により，減弱せしぬ得たるも，DOCA の投 与によつては殆んど影響がない.

\section{第了章 考}

按

Cannon ${ }^{43)}$ (1919) が外的刺战に 対与る反応として想定せる Homeostasis なる機蝺は Adrenalin を媒介と した神経機能，殊に交感神経に重点を置いているのに対し，Selye1（1936）は生体に加えられた広い意味の 㦸㦸を Stress と解し，之の Stress に対しての生体防衛反応に，下垂体副筹皮質系 Hormone が重要な役割 を演ずる事を立証して，一般の注視するる所となつた。

Stress を起す作因即ち Alarm stimuii 乃至 Stressor agents に関してほ，種々の動物実験及び瀶牀観察に 基いて多くのものがあげられているが，其の古には㹨義の環境条件として，気温，殊に寒泠，レ線，日光，

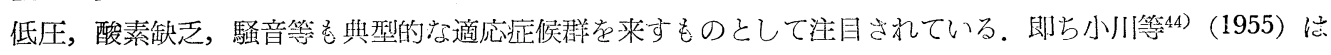
Streessor となるものは，何れも生体外部より生体に与えられ，程度の差てを岸れ所謂内部環境の恒常性 (Homeostasis) の攪乱危来すと考えられる凡ての因子とみてよいと述べている。

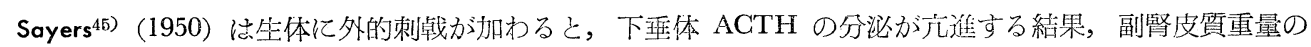
增大を来たすほかに，各種副緊皮質機能九進像を落起すると述べ，Stress の繁に現われる副腎皮質の諸変化 は，下垂体摘出動物では認められないとと及び Stress の際に起る副堅皮翼の Lipoid 顆粒, Cholesterol 及び Ascorbin 酸の減少は，ACTH 投与時に見られる変化と全く同じで岁るとから，Stressにより副筹皮質に 見られる変化は，すべて下兲体 ACTH 在介して起るきのと考えると述べている。

田坂等46)（1953）は副掔摘出が下重体摘出上りを，生体の抵抗減弱の程度に，甚だ大なる影響を有し，且

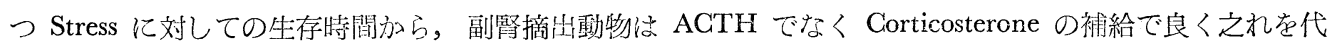
償し，特に Cortisone の投与がよく副腎欠落による抵抗減弱を補う雪を述べている.

Engel ${ }^{47,48)}(1951,1952)$ か N-代塮に於いて，その Catabolic responce の発現速度は直接 AGTH，或いは 副腎 Steroide を投与した時よりも，Stress となる刺战えのものを与えた㭙の方が Cortico-sterone の存在に 於いて，ずつと速かである事を認め，てれは Stress により AGTH，或いは Corticosterone の新たな分泌を 待たずに，既に末梢に存在する Corticosterone だけで刺㦸に対する代謝変化は進行して居るてとを示すもの 
であり，Ingle et al.49（1951）は副婜を摘出して皮㗨 Hormone 学補給された動物と，正常動物とでは，一 定の Stress に対する電解質代謝変化は全く同じである事怘認めている。

田坂等46)（1953）によると，従来 Stress に引続いて副腎の分泌克進が起り，其の結果各種の代謝変化が 起るという単純の概念は次第に反省吟味せねばなら妨としている。

Booker et al.50) (1955) は Zarrow ${ }^{51)}$ (1942) の城したと同じく，何等処留をしない低湿 Stress を与えた 副婜摘出二十日鼠の生存時間は最高 6 時間を出ないと報告している.

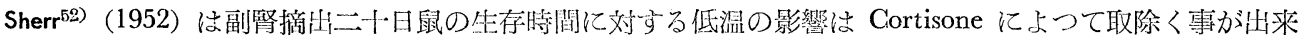
ると報告して居り，又彼は室温に於いては有暳に作用を示す程の高度の Cortisone の量でも，動物が寒冷に 曝露された時は，その有慧性が認められないと報じている。

Booker et al.50) (1955) は $42^{\circ} \mathrm{F}$ の寒冷 Stress 在与えた正常及び副珡摘出二十日鼠の生存時間の延長に対し て Cortisone 及び Ascorbin 酸が其に効果が岕り，Ascorbin 酸は副筒摘出動物よりも正常動物に, より一原 有効に作用すると報告している，尚，正常動物に対して適当量，投与された場合の Cortisone の効果も亦，

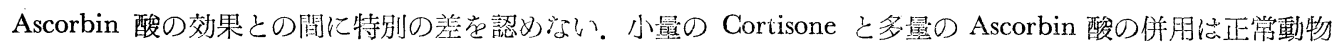

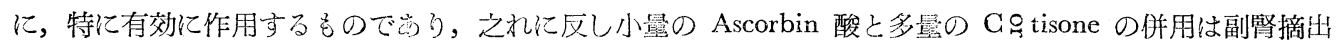
動物に有效に作用すると報告している。

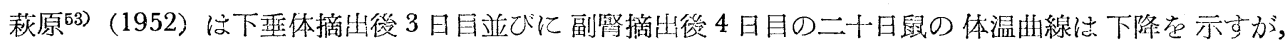
ACTH 10〜 $1 \mathrm{mg} / \mathrm{kg}$ 投与に上り前者出著明に，㷋者は或る程度，阻此し得ると述心゙ている。

田坂等54)（1951）は寒冷反応に及代す ACTH 及び Cortisone の影響に関する実験を行い，健労家鬼の腹 部を急に冷却すると身体各部の温㦄は下降し 3〜 5 分後には顫え点起し，冷却を中止すると又恢復するが， 予め一定量の ACTH を静注して置くと温度下降は軽度で顫えは起らない，又，雨側副婜摘出家鬼に Cortisone と DOCA を一定量筋注すると健常冢鬼と同様の反応在示すが，ACTH，DOCA 及び Cortisone 局 時に投与すると，温度の下降は軽度であると云う。

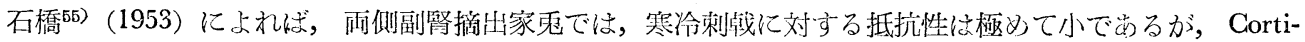
sone, DOCA の投与により健常動物之同様の反応を呈すると述べている。

福田等56)（1954）は家鬼及び犬の副腎摘出衒，テフス-Vaccine による発熱及ひ寒冷に基く直腸温下降及び 循環障碍の状態ふら，副緊摘出後の生体防衛機能の瓦解は Stress に対する循環及び温熱中枢の機能不全に 由来すると報皆している。

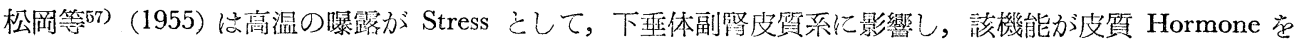
介して塩類代謝を交配し，高温の生体に対する影響を緩和するように㗢くなど，裔熱をStress とみなしての 研究は種々の立場より追及されて居り，高温に懪露した際の循環 Eosin 好坔日血球の態度を追求し，その变

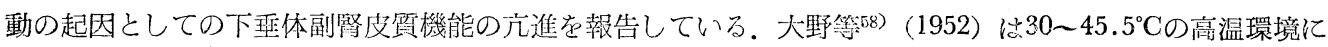
て 8 時間学働を行うものに，DOCA の5〜10mg注射を行つて影響を榆した結果，血液にて比重，色素濃度 低下が著明であつて，血液の稀橎が明らかに認放られるが，DCA 種々の副作用を生ずる危険があり，特 別の場合の外は高熱作業者に使用する事は慎重を要すると報告している．鈴木59（1950）は環境温度の変動 に伴う血液水分と肝組織像との関係に就いて研究し，低温の場合は血液水分減少し，肝細胞は膨大し，高温 環境えの移行は血液水分增加し，肝細胞は縮少すると述べている。

滝童等60) (1955) に上れば，Addison 氏病にては高温曝露に際し 防赭反応の現われが不充分であるが， AGTH，Cortisone により改善されると報告している。阿部61（1956）によると，高温，高湿度状態では， 人の尿中の副粲皮質 Hormone 排泄量は Comp. E, Comp. F 及び Tetrahydro-cortisone に就いては有意の 変化を示さないが，原中の Aldosterone は著しい堌加在示し，之の排淔增加は高熱，高湿度状態に㧊かれた 為の Aldosterone の分泌増加を反映していると報告している.

私の実験に於ける組織呼吸の面よりの梌索に於いても，温度 Stress を与えた場合， Stress を加えざる副腎 摘出動物に見られる肝臓及び瞥蔵の組織呼吸減弱を更に堌大するものの如く，特に雨側副腎摘出の際の低温 


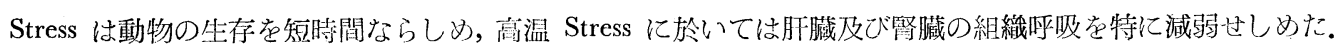
尚，温度 Stress 下に於ける副腎摘法動物の組織呼吸及び生命延長に及ぼす ACTH 及び Cortisone の好影 響は大なるも，DOCA のそれはてれら両 Hormone に及ばない。

\section{第4章 結}

論

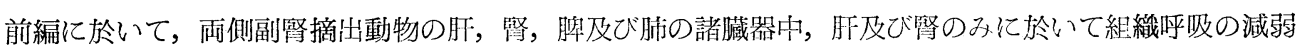
を認めた事を報告した，之の点に関し，更に温度 Stress を加えたる場合，肝及び腎の組織呼吸の驡度如何及 び ACTH, Cortisone 並びに DOGA 投与の影響如何を榆索し，次の結果を得だ。

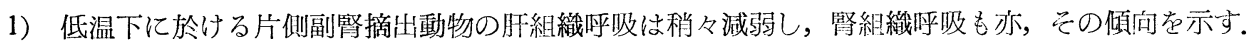

2)低温下に於ける一部副婜残存摘出動物の朋組織呼吸综減弱し，婜組織呼吸も亦，その傾向定示す.

3) 低温下に於いて，一部副腎残存摘出動物に対し ACTH 又は Cortisone の投与法朋及び腎組織呼吸を 回復する:

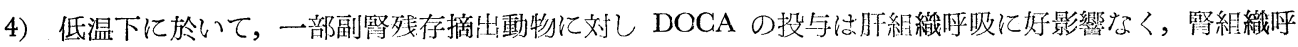
吸も亦, 減弱の傾向を示す.

5）高温下に於ける一部副腎残存摘出動物の肝組織呼吸は減弱し，算組織呼吸も亦，その傾向を示す.

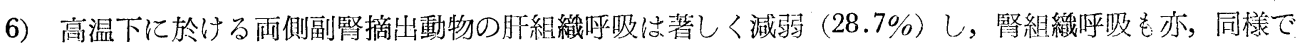
ある。

7）高温下に於いて，両側副腎摘出動物に対し Cortisone の投与は肝及び䟧の組織呼吸を回復せしぬる.

8)高温下に於いて，雨側副腎摘出動物に対し DOCA の投与は朋組織呼吸に好影響なきも，粲組織呼吸 の回復を認める。

9) 低温下に於ける副腎摘出後の死亡率は，両侧摘出群最も高く，一部残存摘出群，片側摘出群の順に低 い，一部残存摘出群に対する ACTH 及び皮質 Hormone 投与の影響を見るに，Cortisone 投与群の死亡率 最も低く, ACTH, DOGA 投与群沙之れに次ぐ。

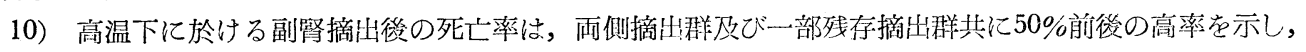
両側摘出群に対し Cortisone の投与は非常に效果的で峉るが，DOCA は死亡率の点に於いて殆んど効果を 珰访る事は出来ない。

\section{第 3 篇 副腎摘出の内分泌蔵器組織呼吸に及ぼす影響}

\section{第1章 実 験 方 法}

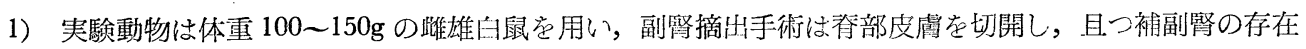
を考虑して副腎の周囲絽織を可及的広範囲に摘出し，対照動物に副腎を摘出せぬ。範囲で同様な手術的侵襲を 加えた．摘出及び対照手術には軽い Aether 麻酔を用い，両側一次的摘出法によつた。

実験動物の飼育温度は可及的定温度に保ち，且つ飼料は大麦，野菜及び水を与え，副婜摘出動物には $1 \%$ 食塩水を投与した。

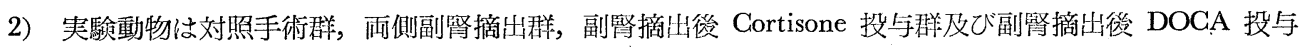

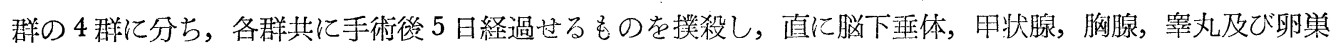
を摘出し，且つ脳下垂体及び甲状腺は組織重量僅少のため同一条件の 2 匹局いて，之れを実験に供した。

Cortisone としては Scheroson (Schering) を用い，両側副掔摘出徐，每日 $5 \mathrm{mg}$ 宛 5 回腹腔内に注射し， DOCA は Syncorta (Takeda) 点用い，同しく每日0.5mg宛 5 回脊部皮下に注射した。

3）組織呼吸测定は Warburg 氏检圧法によつた。

a) 浮遊液は $0.2 \%$ 糖加呼吸用 Ringer 氏液を用いた。

b) 実験操作及び Ringer 氏液の組成䛱第 1 篇に詳述した如くである。 


\section{第 2章 実 験 成 績 \\ 第 1 節 両側副腎摘出実験}

1) 対照白鼠の各種内分泌㵴器組織呼吸

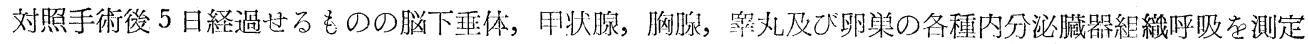
した結果は次の如くで岕る (第32，33表).

策32表 雨側副䇰摘出対照手術群（雄性）に於ける二，三内分泌腺の $\mathrm{QO}_{2}$

\begin{tabular}{|c|c|c|c|c|c|c|c|c|c|c|c|c|c|c|c|c|}
\hline \multirow{3}{*}{ 番号 } & \multicolumn{4}{|c|}{ 脳下垂 体 } & \multicolumn{2}{|r|}{ 甲 } & 状 & 腺 & \multicolumn{2}{|r|}{ 胸 } & \multicolumn{2}{|l|}{ 腺 } & \multicolumn{2}{|r|}{ 罳 } & \multicolumn{2}{|l|}{ 丸 } \\
\hline & \multirow{2}{*}{$\begin{array}{l}\text { 組織 } \\
\text { 重量 } \\
\text { (mg) }\end{array}$} & \multicolumn{2}{|c|}{$\mathrm{Xo}_{2}$} & \multirow{2}{*}{ Qo.2. } & \multirow{2}{*}{ 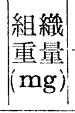 } & \multicolumn{2}{|c|}{$\mathrm{Xo}_{2}$} & \multirow{2}{*}{$\mathrm{QO}_{2}$} & \multirow{2}{*}{$\mid \begin{array}{l}\text { 組織 } \\
\text { 重量 } \\
(\mathrm{mg})\end{array}$} & \multicolumn{2}{|c|}{$\mathrm{Xo}_{2}$} & \multirow{2}{*}{$\mathrm{Qo}_{2}$} & \multirow{2}{*}{$\left|\begin{array}{c}\text { 組織 } \\
\text { 重量 } \\
(\mathrm{mg})\end{array}\right|$} & \multicolumn{2}{|c|}{$\mathrm{Xo}_{2}$} & \multirow{2}{*}{$\mathrm{QO}_{2}$} \\
\hline & & $30^{\prime}$ & $60^{\prime}$ & & & $30^{\prime}$ & $60^{\prime}$ & & & $30^{\prime}$ & $60^{\prime}$ & & & $30^{\prime}$ & $60^{\prime}$ & \\
\hline 1) & 1.18 & 5.042 & 8.206 & 6.95 & 1.75 & 8.393 & 14.497 & 8.28 & 3.35 & 15.232 & 29.702 & 8.86 & 4.8 & 19.457 & 739.639 & 98.25 \\
\hline 2$\}$ & & & & & & & & & 3.42 & 13.61 & 28.274 & 8.72 & 5.8 & 23.464 & 45.754 & 7.88 \\
\hline $\left.\begin{array}{l}3 \\
4\end{array}\right\}$ & 1.2 & 6.714 & 11.232 & 9.36 & 2.25 & 7.019 & 12.208 & 5.42 & $\mid \begin{array}{l}3.55 \\
4.15\end{array}$ & $\begin{array}{l}17.871 \\
20.944\end{array}$ & $\begin{array}{l}34.040 \\
34.652\end{array}$ & $\begin{array}{l}9.58 \\
8.35\end{array}$ & 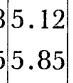 & $\begin{array}{l}14.748 \\
19.457\end{array}$ & $\begin{array}{l}29.413 \\
33.847\end{array}$ & $\begin{array}{l}5.74 \\
5.78\end{array}$ \\
\hline$\left.{ }_{6}^{5}\right\}$ & 1.4 & 6.833 & 11.563 & 8.25 & 2.3 & 13.162 & 25.179 & 10.94 & $\mid \begin{array}{l}3.25 \\
3.08\end{array}$ & $\begin{array}{l}16.147 \\
3.804\end{array}$ & $\begin{array}{l}31.912 \\
24.752\end{array}$ & $\begin{array}{l}9.81 \\
8.03\end{array}$ & $\begin{array}{l}5.43 \\
4.45\end{array}$ & $\begin{array}{l}15.837 \\
14.503\end{array}$ & $\begin{array}{l}28.960 \\
27.654\end{array}$ & $\begin{array}{l}5.33 \\
6.21\end{array}$ \\
\hline $\left.\begin{array}{l}7 \\
8\end{array}\right\}$ & 1.2 & 5.937 & 10.444 & 8.70 & 1.7 & 6.248 & 11.826 & 6.95 & $\begin{array}{l}4.02 \\
3.3\end{array}$ & $\begin{array}{l}18.998 \\
14.660\end{array}$ & $\left|\begin{array}{l}36.593 \\
27.608\end{array}\right|$ & $\begin{array}{l}9.10 \\
8.36\end{array}$ & $\begin{array}{l}4.75 \\
4.3\end{array}$ & $\begin{array}{l}13.760 \\
11.480\end{array}$ & $\left\{\begin{array}{l}26.245 \\
21.788\end{array}\right.$ & $\begin{array}{l}5.52 \\
5.06\end{array}$ \\
\hline $\left.\begin{array}{r}9 \\
10\end{array}\right\}$ & 1.1 & 5.595 & 11.022 & 10.02 & 1.58 & 7.393 & 12.360 & 7.82 & $\begin{array}{l}3.95 \\
4.18\end{array}$ & $\begin{array}{l}19.998 \\
19.420\end{array}$ & $\begin{array}{l}37.444 \\
37.889\end{array} \mid$ & $\begin{array}{l}9.47 \\
9.06\end{array}$ & $\begin{array}{l}4.6 \\
5.42\end{array}$ & $\begin{array}{l}15.837 \\
17.436\end{array}$ & $\left\{\begin{array}{l}29.774 \\
33.603\end{array}\right.$ & $\begin{array}{l}6.47 \\
6.19\end{array}$ \\
\hline $\begin{array}{l}\text { 平均 } \\
\text { 值 }\end{array}$ & & & & 8.65 & & & & 7.88 & & & & 8.93 & & & & 6.24 \\
\hline
\end{tabular}

第33表 両側副腎摘出対照手術群（雌性）に於ける二，三内分泌腺の Qo 2

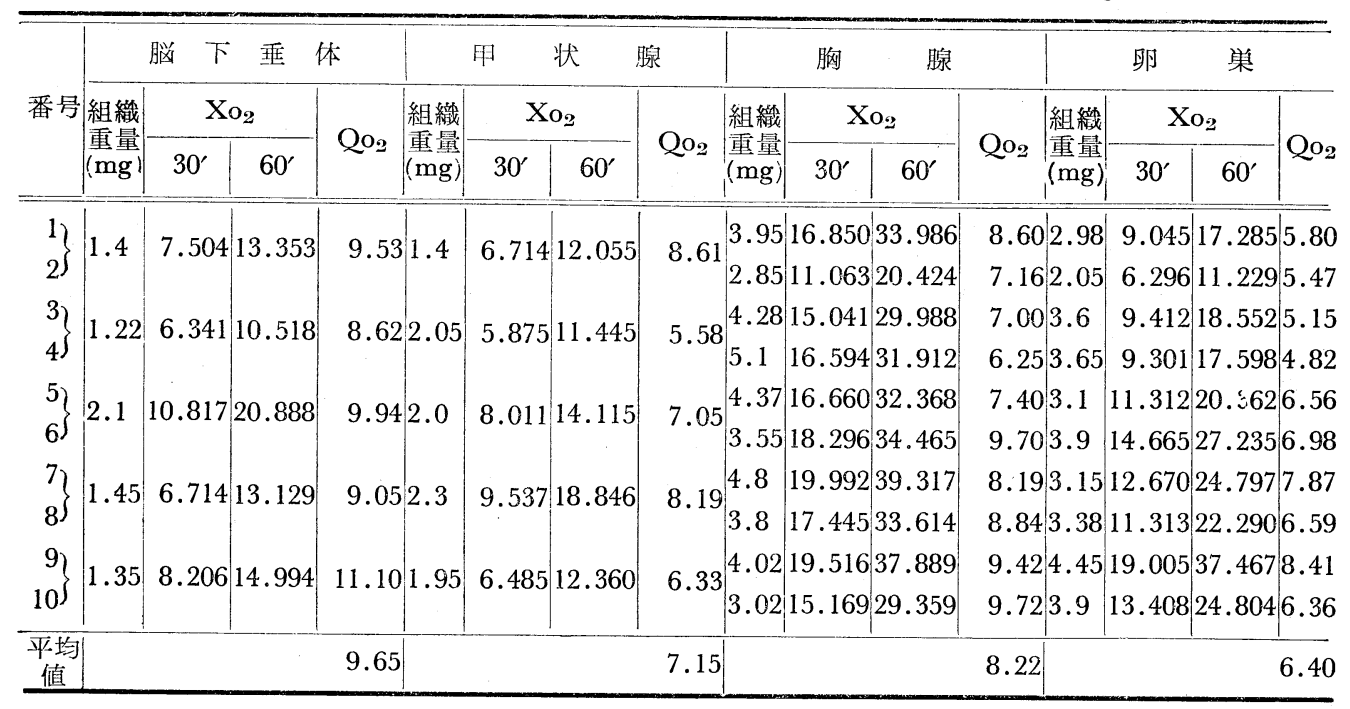

\section{a) 䎩下垂体}

$0.2 \%$ 糖加 Ringer 氏液中の脳下重体組織呼吸は雄性動物に於いては 5 例中最大值 10.02 , 最小值 6.95 そし 
て平均值は8.65である。雌性動物に於いては 5 例中最大値 11.10 , 最小值8.62にして平均值は9.65である。 雌雄両性の平均値は9.15である。

\section{b) 甲状腺}

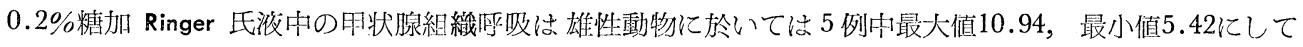
平均値は7.88でする。雌性動物に於いては 5 例中最大值 8.61 , 最小值 5.58 亿して平均值は7.15である。雌雄 両性の平均值は7.51で西る。

\section{c) 胸腺}

$0.2 \%$ 糖加 Ringer 氏液中の胸腺組織呼吸仿雄性動物飞於いては10例中最大值 9.81 , 最小值8.03にして平均 值は8.93である。雌性動物に於いては10例中最大值 9.72 , 最小值6.25亿して平均值は8.22である。唯雄両性 の平均值は8.57である。

\section{d）蟠丸}

$0.2 \%$ 糖加 Ringer 氏液中の䈉丸組織呼吸住10例中最大值 8.25 , 最小値 5.06 亿して平均值は6.24である。

e) 卵巣

$0.2 \%$ 糖加 Ringer 氏液中の卵巣組織呼吸は10例中最大值 8.41 ，最小値 4.82 亿して平均值は6.40でらる。

2) 両側副腎摘出白鼠の各種内分泌臟器組織呼吸

両側副腎摘出後 5 日経過せるものの脳下垂体，甲状腺，胸腺，等丸及び卵巣の各種内分泌臟器組織呼吸を 測定した結果怯次の如くである（第34，35表).

\section{a) 惱下垂体}

$0.2 \%$ 糖加 Ringer 氏液中の脳下垂体組織呼吸は雄性動物に於いては 5 例中最大值 10.71 ，最小值8.49亿乙

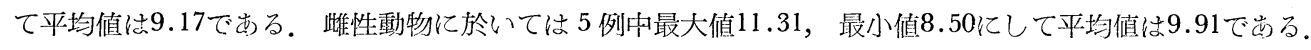
雌雄両性の平均值は9.54で劣る。

\section{b) 甲狀腺}

$0.2 \%$ 糖加 Ringer 氏液中の甲状腺組織呼吸は雄性動物に於いては 5 例中最大值 9.20 , 最小值 6.57 亿て平 均值は7.57である. 雌性動物に於いては 5 例中最大值 10.18 , 最小值 6.10 亿して平均値は8.04である。雌雄

第34表 両側副腎摘出群（雄性）飞於ける二，三内分泌腺の $\mathrm{Qo}_{2}$

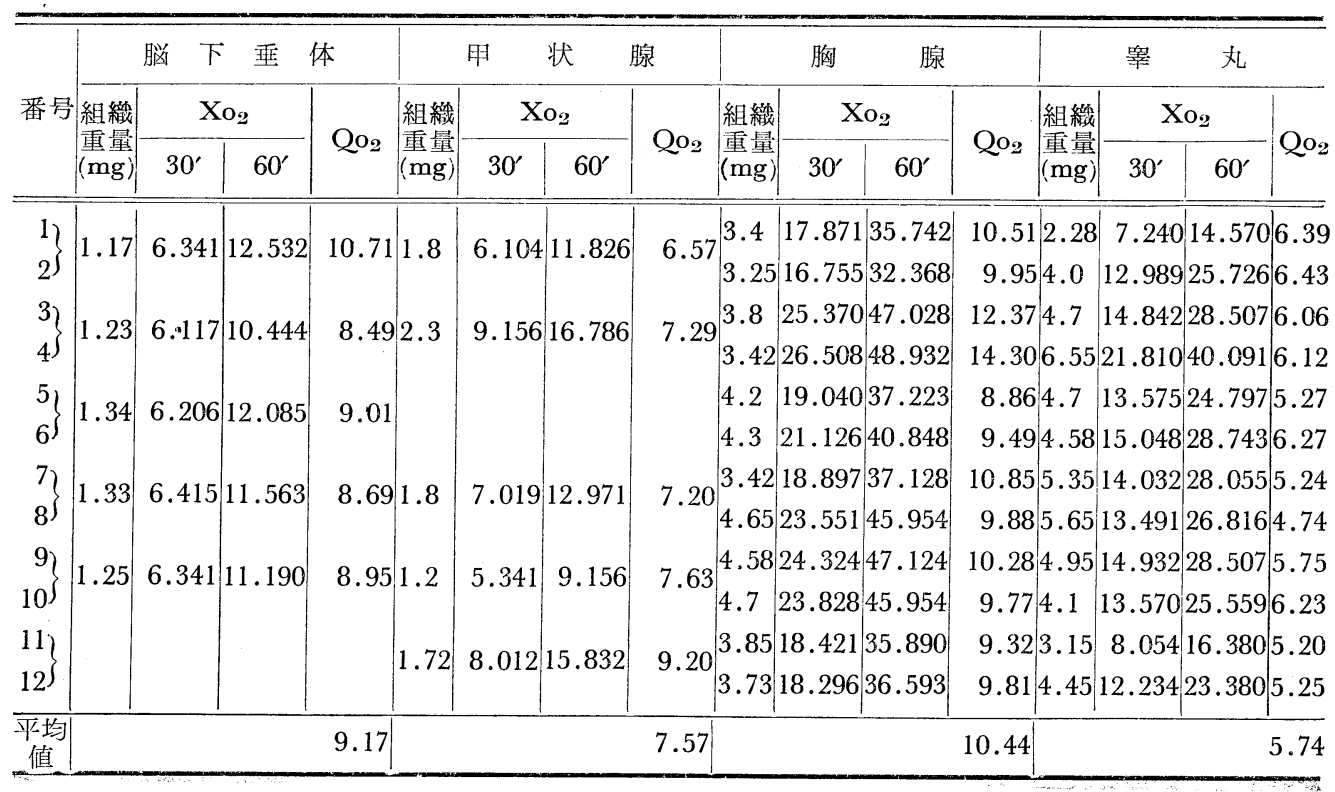


第35表 両側副婜摘出群（雌性）に於ける二，三内分泌腺の Qo

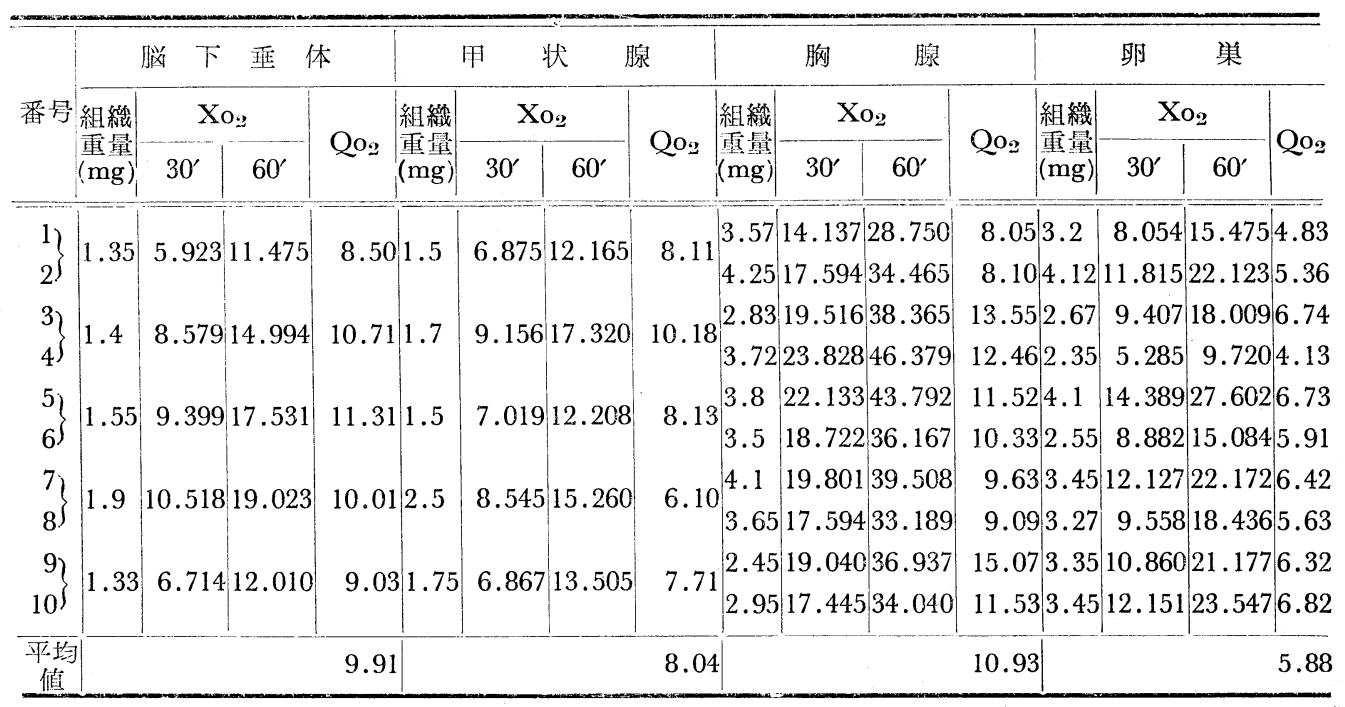

雨性の平均值は7.80である。

\section{c) 胸腺}

$0.2 \%$ 糖加 Ringer 氏液中の胸腺組織呼吸は雄性動物に於いては12例中最大值 14.30 , 最小值8.86にして平 均值は10.44で心る。雌性動物にては10例中最大值 15.07，最小值8.05亿して平均值は10.93である。雌性両 性の平均值は10.68である。

\section{d). 賓丸}

$0.2 \%$ 糖加 Ringer 氏液中の莘丸組織呼吸は12例中最大值 6.43 ，最小值 4.74 亿て平均值は5.74である。

\section{e) 卵巣}

$0.2 \%$ 糖加 Ringer 氏液中の卵巣組織呼吸は10例中最大値 6.82 ，最小偡4.13にして平均值は5.88である。

3) 本節小括

雌雄雨性白鼠の雨側副腎摘出後 5 日経過 せるものの各種内分泌蔵器組織呼吸に及ほ す影響を梌索し，要約して次の結果在得た (第36表).

a) 対照手術群の脳下垂体組織呼吸の平 均值は9.15にして，両側副腎摘出群の平均 值は9.54にして対照に比して其の間に著差 を認めない?

b) 対照手術群の甲状腺組織呼吸の平均
第36表 両侧副腎摘出後の各種内分泌腺臓器組織呼吸

\begin{tabular}{|c|c|c|c|}
\hline & $\begin{array}{c}\text { 対照手術群 } \\
\text { (例数) }\end{array}$ & $\begin{array}{l}\text { 両側摘出群 } \\
\text { (例数) }\end{array}$ & $\%$ \\
\hline 脸下垂体 & $9.15(10)$ & $9.54(10)$ & $+4.2 \%$ \\
\hline 甲状䏮 & $7.51(10)$ & $7.80(10)$ & $+3.8 \%$ \\
\hline 胸腺 & $8.57(20)$ & $10.68(22)$ & $+24.6 \%$ \\
\hline 辠丸 & $6.24(10)$ & $5.74(12)$ & $-8.0 \%$ \\
\hline 卵巣 & $6.40(10)$ & $5.88(10)$ & $-8.1 \%$ \\
\hline
\end{tabular}

值は7.51，両側副腎摘出群の平均值は7.80亿して其の間に著差を認めない.

c）対照手術群の胸腺組織呼吸の平均值は8.57, 雨側副腎摘出群の平均值は10.68にして対照に比して 24.6 \%の著明なえ進を認める。

d) 対照手術群の睪丸組織呼吸の平均倠は6.24，両側副留摘出群の平均值は5.74にして対照に比して8.0 \%減弱の傾向を詞む。

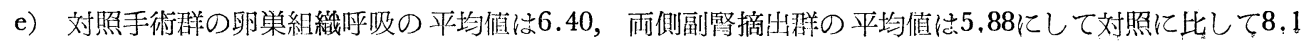
\%減弱の傾向を認む。 


\section{第 2 節 副婜摘出後皮質ホルモンによる代償作用}

1）雨側副繁摘出後 5 日間，毎日 Cortisone を $5 \mathrm{mg}$ 宛，腹腔内に注射しだ場合の脳下垂体，甲状腺，胸

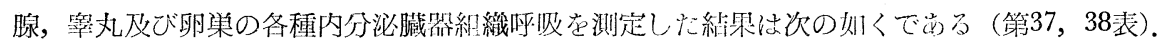

管37表 両側㣂腎摘出後 Cortisone 投与群（雄性）に於ける二，二内分泌腺の Qo:

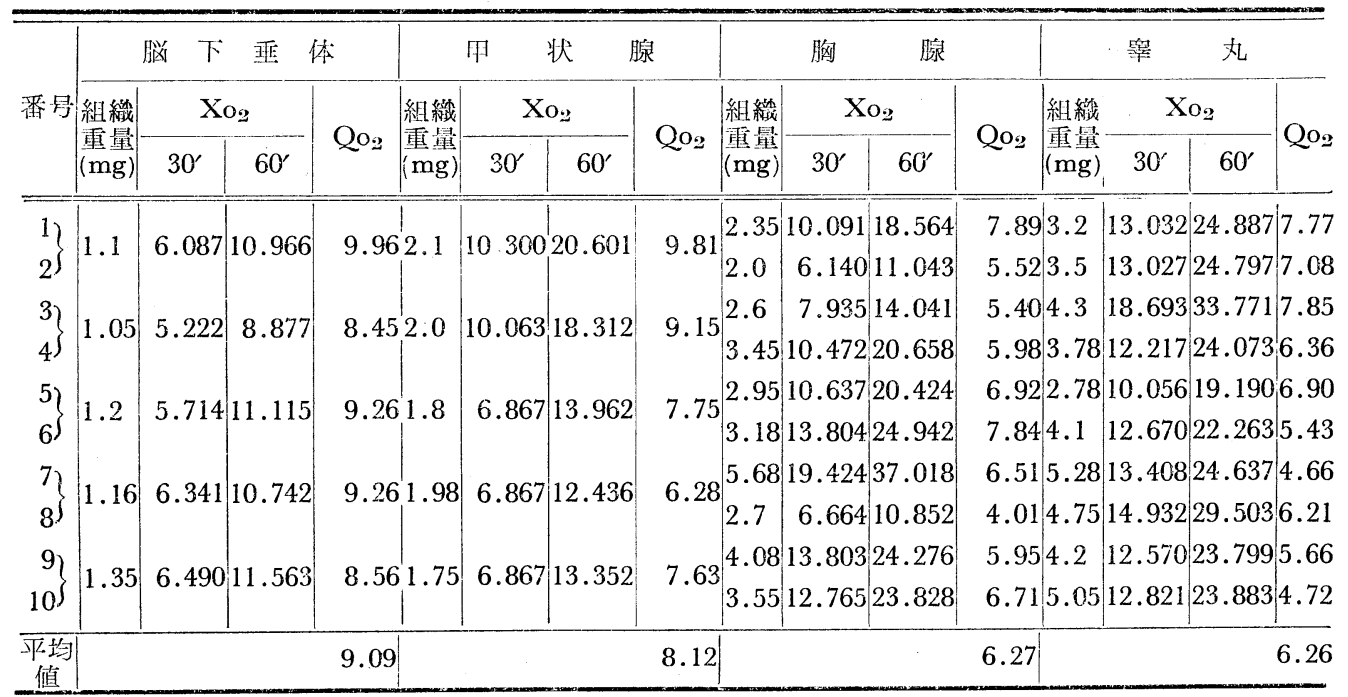

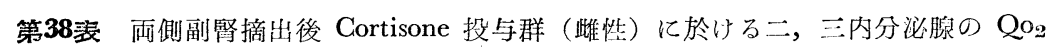

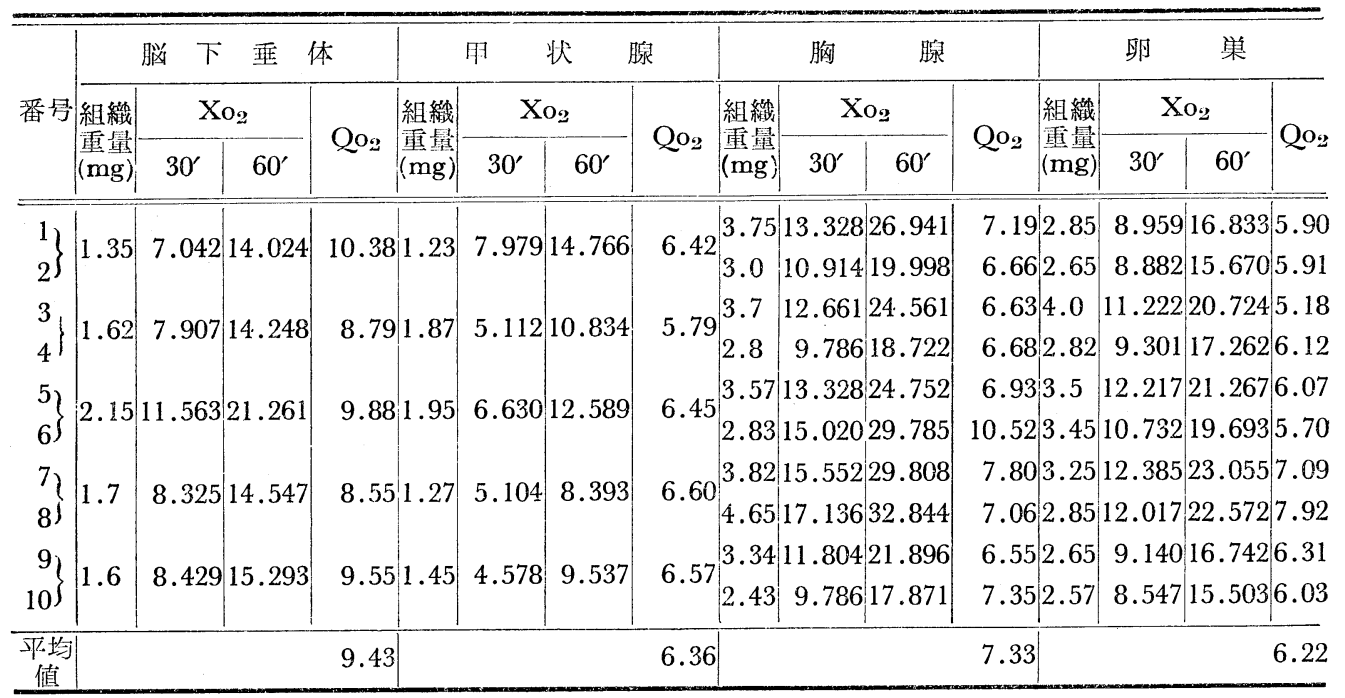

\section{a) 腦下垂体}

$0.2 \%$ 糖加 Ringer 氏液中の脳下垂体組織呼吸に雄性動物に於いては 5 例中最大値 9.96 , 最小值 8.45 亿て 平均值は9.09である。雌性動物に於いては 5 例中最大值 10.38 ，最小值 8.55 亿し平均值は9.43でらる。雌 雄雨性の平均値伈9.26である。

b) 甲奘腺 


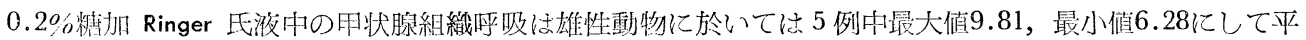

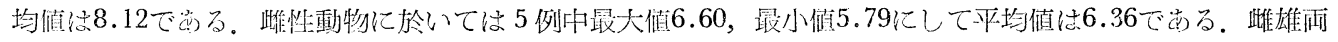
性の平均储は7.24で市る。

c) 胸腺

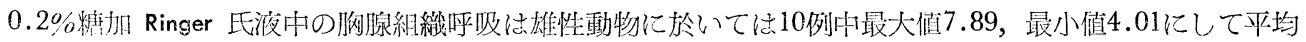

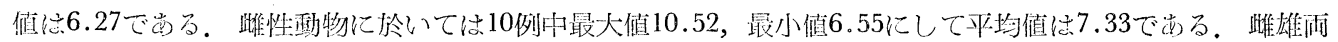
性の平均值恼6.80で京る。

d) 蔁丸

$0.2 \%$ 糖加 Ringer 氏液中の睪丸組織呼吸は10例中最大值7.85，最小值4.66亿して平均值は6.26である。

e) 卵巣

$0.2 \%$ 頪加 Ringer 氏淮中の卵巣組織呼吸は10例中最大值7.92，最小値5.18にして平均值は6.22で方る。

2) 两側副婜摘出後 5 日間，毎日 DOGA $0.5 \mathrm{mg}$ 施，脊部度下に注射した場合の脳下垂体，甲状腺，胸

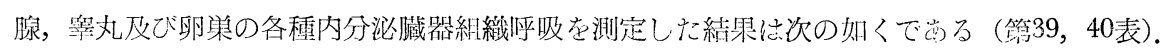

\section{a) 腦下垂体}

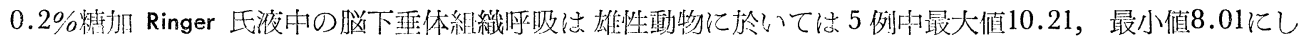

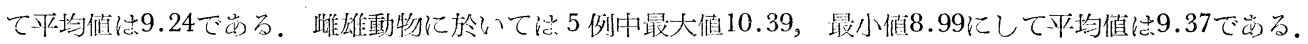
䧳雄两性の平均值は9.30で岕る。

\section{b) 甲狀腺}

$0.2 \%$ 糖加 Ringer 氏液中の甲状腺組織再吸は雄性動物に於いては 5 例中最大值 10.92 , 最小值 6.14 亿て

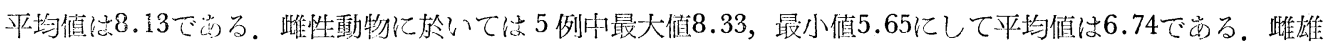
両性の平均值は7.43である。

c) 胸腺

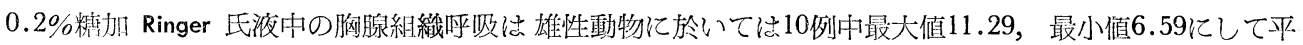
均值に9.26である。雌性動物に於いては10例中最大值 10.30 ，最小值7.23にして平均值は8.93である。雌雄 雨性の平均值浪9.09である。

d）殬丸

第39表 両側副腎摘出後 DOCA 投与群（雄性）に於ける二，三内分泌腺の $\mathrm{Qo}_{2}$

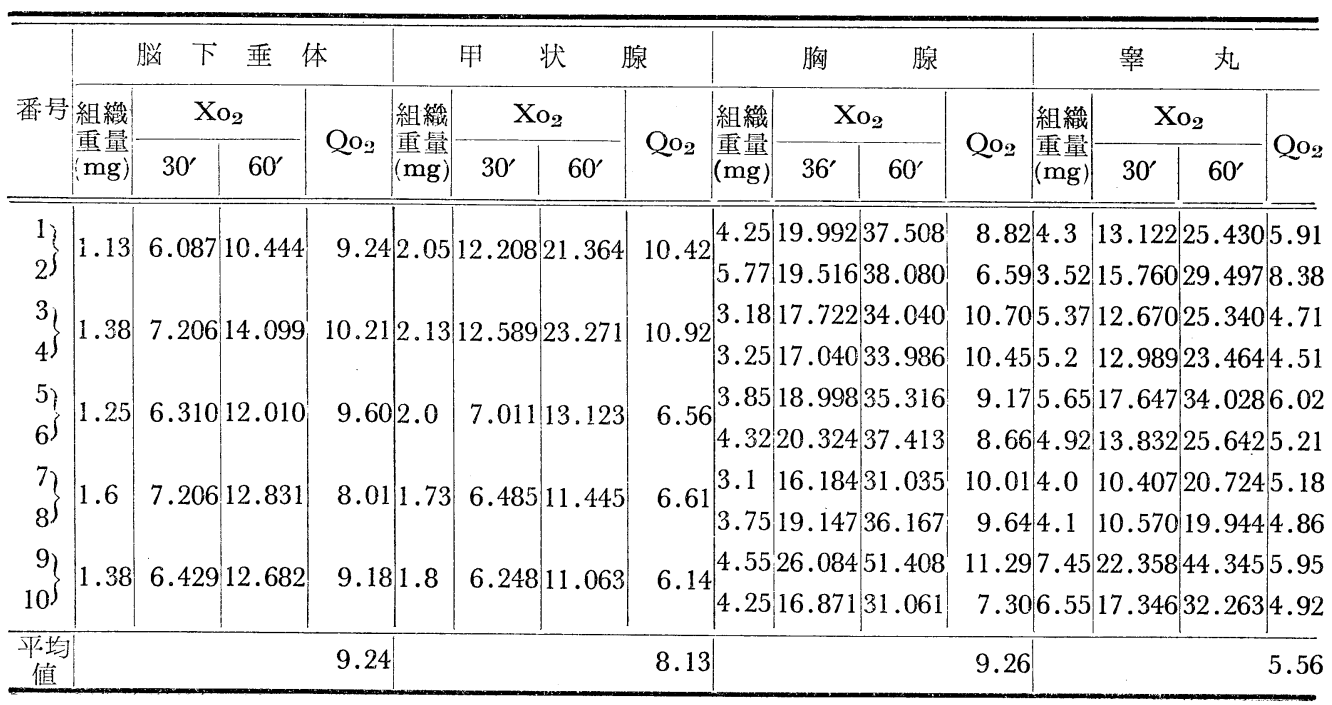


第40表 両側副腎摘出後 DOCA 投与群 (雌性) 飞於ける二，三内分泌腺の Qog

\begin{tabular}{|c|c|c|c|c|c|c|c|c|c|c|c|c|c|c|c|c|}
\hline \multirow{3}{*}{ 番帯 } & \multicolumn{4}{|c|}{ 脳下垂 体 } & \multicolumn{3}{|r|}{ 状 } & 泉 & \multicolumn{4}{|c|}{ 胸 } & \multicolumn{4}{|c|}{ 卵 } \\
\hline & \multirow{2}{*}{ 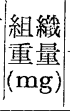 } & \multicolumn{2}{|c|}{$\mathrm{Xo}_{2}$} & \multirow{2}{*}{$\mathrm{Qo}_{2}$} & \multirow{2}{*}{ 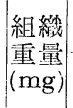 } & \multicolumn{2}{|c|}{$\mathrm{Xo}_{2}$} & \multirow{2}{*}{$\mathrm{QO}_{2}$} & \multirow{2}{*}{ 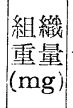 } & \multicolumn{2}{|c|}{$\mathrm{Xo}_{2}$} & \multirow{2}{*}{$\mathrm{QO}_{2}$} & \multirow{2}{*}{ 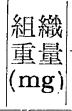 } & \multicolumn{2}{|c|}{$\mathrm{QO}_{2}$} & \multirow{2}{*}{ Qo. } \\
\hline & & $30^{\prime}$ & $60^{\prime}$ & & & $30^{\prime}$ & $60^{\prime}$ & & & $30^{\prime}$ & $60^{\prime}$ & & & $30^{\prime}$ & $60^{\circ}$ & \\
\hline $\left.\begin{array}{l}1 \\
2\end{array}\right\}$ & 1.28 & 6.595 & 11.936 & 9.32 & 1.35 & 4.196 & 7.630 & 5.65 & $\left|\begin{array}{l}3.65 \\
3.22\end{array}\right|$ & $\begin{array}{l}14.28 \\
12.76\end{array}$ & $\left|\begin{array}{l}29.988 \\
25.104\end{array}\right|$ & $\begin{array}{l}8.21 \\
7.79\end{array}$ & $\left|\begin{array}{l}2.85 \\
3.0\end{array}\right|$ & $\begin{array}{l}6.335 \\
9.218\end{array}$ & \begin{tabular}{l|l}
5 & 13.122 \\
8 & 16.760
\end{tabular} & $\begin{array}{l}4.60 \\
5.58\end{array}$ \\
\hline $\left.\begin{array}{l}3 \\
4\end{array}\right\}$ & 1.63 & 7.609 & 14.920 & 9.15 & 1.45 & 4.959 & 8.774 & 6.05 & $\begin{array}{l}3.95 \\
3.15\end{array}$ & $\begin{array}{l}13.89 \\
15.31\end{array}$ & $\left|\begin{array}{l}28.560 \\
30.636\end{array}\right|$ & $\begin{array}{l}7.23 \\
9.72\end{array}$ & 2.57 & $\begin{array}{l}7.602 \\
6.536\end{array}$ & $\begin{array}{ll}2 & 14.027 \\
6 & 11.732\end{array}$ & 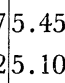 \\
\hline $\left.\begin{array}{l}5 \\
6\end{array}\right\}$ & 2.07 & 9.698 & 18.650 & 9.00 & 2.15 & 9.300 & 17.930 & 8.33 & $\begin{array}{l}4.1 \\
3.55\end{array}$ & $\begin{array}{l}19.51 \\
19.99\end{array}$ & $\left|\begin{array}{l}36.652 \\
36.593\end{array}\right|$ & $\begin{array}{r}8.93 \\
10.30\end{array}$ & $\begin{array}{l}3.3 \\
2.67\end{array}$ & $\begin{array}{l}13.122 \\
10.475\end{array}$ & \begin{tabular}{l|l}
2 & 25.340 \\
5 & 18.017
\end{tabular} & $\begin{array}{l}7.67 \\
6.74\end{array}$ \\
\hline $\left.\begin{array}{l}7 \\
8\end{array}\right\}$ & 1.7 & 8.206 & 15.293 & 8.99 & 1.78 & 6.248 & 11.826 & 6.64 & $\begin{array}{l}4.38 \\
4.35\end{array}$ & $\begin{array}{l}19.51 \\
20.42\end{array}$ & $\left|\begin{array}{l}38.080 \\
39.571\end{array}\right|$ & $\begin{array}{l}8.69 \\
9.09\end{array}$ & $\begin{array}{l}3.52 \\
4.15\end{array}$ & $\begin{array}{l}11.575 \\
15.760\end{array}$ & \begin{tabular}{l|l}
5 & 21.720 \\
0 & 29.749
\end{tabular} & $\begin{array}{l}6.17 \\
7.16\end{array}$ \\
\hline $\left.\begin{array}{r}9 \\
10\end{array}\right\}$ & 1.93 & 10.220 & 20.067 & 10.39 & 2.58 & 9.919 & 18.159 & 7.03 & $\begin{array}{l}4.35 \\
2.9\end{array}$ & $\begin{array}{l}20.08 \\
15.74\end{array}$ & $\left|\begin{array}{l}40.174 \\
29.359\end{array}\right|$ & $\begin{array}{r}9.23 \\
10.12\end{array}$ & $\left|\begin{array}{l}3.18 \\
3.22\end{array}\right|$ & $\begin{array}{l}11.674 \\
12.240\end{array}$ & \begin{tabular}{l|l}
4 & 21.358 \\
0 & 23.799
\end{tabular} & $\begin{array}{l}6.71 \\
7.39\end{array}$ \\
\hline $\begin{array}{c}\text { 平均 } \\
\text { 值 }\end{array}$ & & & & 9.37 & & & & 6.74 & & & & 8.93 & & & & 6.25 \\
\hline
\end{tabular}

$0.2 \%$ 糖加 Ringer 氏液中の等丸組織呼吸は10例中最大値8.38，最小值4.51亿して平均值は5.56である。

e) 卵巣

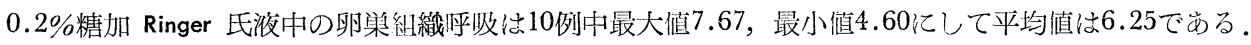

3) 本節小括

雌雄両性白鼠の両側副腎摘出後 Cortisone 或いは DOGA を投与せるものの各種内分泌蔵器組織呼吸に及 ぼす影響を检索し，要約して次の結果を得た (第41表).

第41表 両側副粲摘出後皮質 Hormone 投与せる各種内分泌臟器組織呼吸

\begin{tabular}{|c|c|c|c|c|c|}
\hline & $\begin{array}{l}\text { 対照手術群 } \\
\text { (例数) }\end{array}$ & \begin{tabular}{|c|}
$\begin{array}{c}\text { 両側副书摘出後 } \\
\text { Cortisone 投与群 } \\
\text { (例数) }\end{array}$ \\
\end{tabular} & $\pm \quad \%$ & $\begin{array}{c}\text { 兩側副腎摘出後 } \\
\text { DOCA 投与群 } \\
\text { (例数) }\end{array}$ & $\pm \quad \%$ \\
\hline 脳下垂体 & $9.15(10)$ & $9.26(10)$ & $+1.2 \%$ & $9.30(10)$ & $+1.6 \%$ \\
\hline 甲状腺 & $7.51(10)$ & $7.24(10)$ & $-3.7 \%$ & $7.43(10)$ & $-1.0 \%$ \\
\hline 胸腺 & $8.57(20)$ & $6.80(20)$ & $-20.6 \%$ & $9.09(20)$ & $+6.0 \%$ \\
\hline 啈丸 & $6.24(10)$ & $6.26(10)$ & $+0.3 \%$ & $5.56(10)$ & $-10.8 \%$ \\
\hline 卵策 & $6.40(10)$ & $6.22(10)$ & $-2.8 \%$ & $6.25(10)$ & $-2.3 \%$ \\
\hline
\end{tabular}

a) 両側副婜摘出後 Cortisone 又心 DOGA 投与群の脳下垂体組織呼吸は刘照に比して始んど差を認めな ?.

b) 雨側副婜摘出䘗 Cortisone 又心 DOCA 投与群の甲状腺組織呼吸は対照に比して著差を認めない.

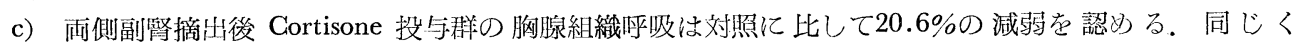
DOCA 投与群に於いては僅かに古進状態に市る。

d) 两側副筝摘出後 Cortisone 投与群の罣丸組織呼吸は刘照に比して名んど差を認めざるも，DOGA 投 与群では10.8\%減弱する。

e) 両側副腎摘出徐 Cortisone 又心 DOCA 投与群の卵柴組織呼吸は刘照に比して始んど差を認》ない.

\section{第 3 節副腎摘出と胸腺重量}

体重 110〜130g の雄性旨鼠に於いて，雨側副腎摘出 5 日経過後に於ける胸腺重量に及代す影響並びに副婜 
摘出後 Cortisone 又は DOCA を前述の量及び方法を以つて投与せる場合の胸腺重量に及ばす影響如何を検 すべく実験を行い，組織重量は Torsion balance により体重 $100 \mathrm{~g}$ 当りの重量測定を行い，次の結果を得た (第42表).

第42表 副雨摘出之胸腺重量

\begin{tabular}{|c|c|c|c|c|c|}
\hline & \multirow{2}{*}{ 例 数 } & \multicolumn{3}{|c|}{ 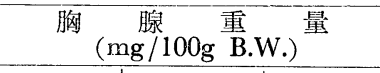 } & \multirow{2}{*}{ \pm} \\
\hline & & 最大值 & 最小值 & 平均值 & \\
\hline 対照手術群 & 6 & 172 & 107 & 143 & \\
\hline 両側副筲摘出群 & 6 & 261 & 137 & 212 & $+48.2 \%$ \\
\hline 副憼摘出後 Cortisone 投与群 & 5 & 101 & 43 & 75 & $-47.5 \%$ \\
\hline 副掔摘出後 DOCA 投与群 & 8 & 268 & 131 & 172 & $+20.2 \%$ \\
\hline
\end{tabular}

即ち両側副婜摘出動物の胸腺重量络対照に比して $48.2 \%$ 著明な增加を認め, 副腎摘出後 Cortisone 投与 群は逆に $47.5 \%$ の重量減少を来たし，副粲摘出後 DOCA 投与群に於いては20.2\%の重量增加を認める。

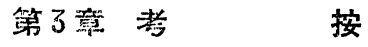

\section{1) 腦下垂体と副腎}

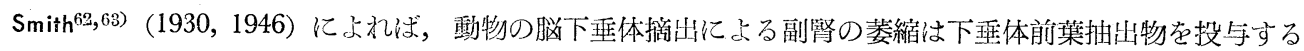
か或い:下西体を移植すると完全に回復する事から，下垂体が副㹂皮質を高度に支配している事か明らかと なつた．Sayers45)（1950）によると，生体に外的刺戟が加えられた場合に下垂体の ACTH 分泌が圥進する

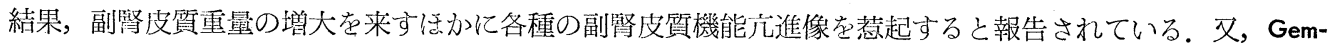
zell et al.64) (1951) によると, 両側副腎摘出は下垂体前葉の ACTH 分泌を九市て, 未梢血の ACTH 量も 增加するため，多分一側副腎摘出時にも同様に ACTH の分泌増加が起り，残存副珡肥大を苾起するので弟 万うと考觉られている。 Ingle et al.65) (1937)，Ingle ${ }^{66)}$ (1939) 飞よると，下垂体前葉の ACTH 分泌は標的

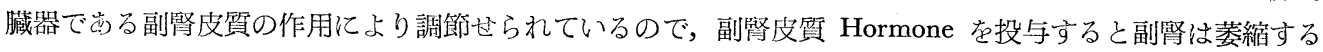
と述べて居り，鎮目及び Levner 77 ) (1954) は Addison 氏病㭧者の尿中 Melanin 細胞刺㦸 Hormone (M.S.H.)

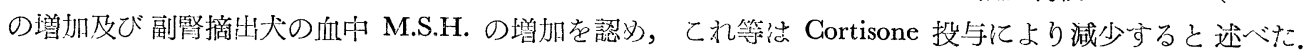

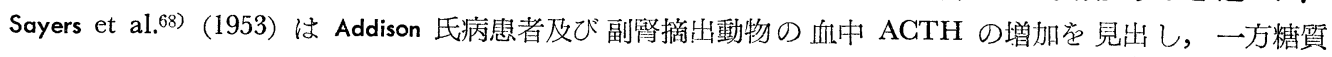
Corticoids の過剩状態に於いて虻 ACTH の分泌機能が娍退して居り，Cushing 氏症候群や Cortisone 長期 投与を受引ている患者が Stress に反応し難いと述べている．Addison 氏病患者の血中抗利尿物質の増加は Lloyd $^{(9)}$ (1950)，Slessor ${ }^{70)}$ (1951)，矢野71) (1952) 飞より，尿中抗利尿物質の增加は Dochias ${ }^{72)}$ (1951) によ り報告されている。乙れ结下垂体よりの分泌增加よりも，肝臟に於ける破壊抑制によるてめと解されている。

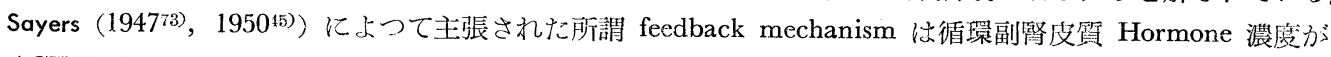

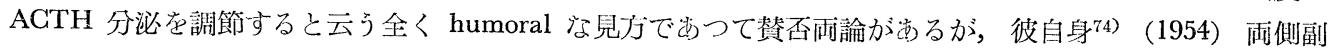
腎摘除後即ち循環副等皮質 Hormone の全く欠如した状態に於いても， Stress に反応して ACTH の分必

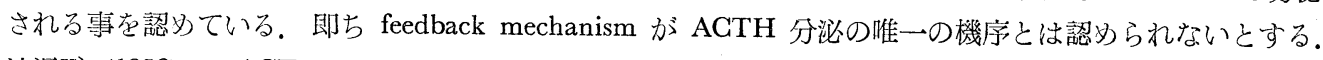

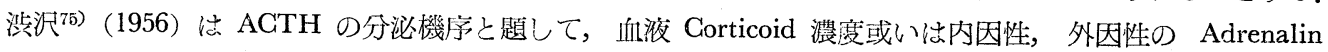
が ACTH 分泌の natural Stimulator と見做し難く，气の humoral の因子は視床下部少台遊離する neurohormone 即ち Vasopressin であるうと結んでいる。

脳下垂体前葉一副粲皮質系に関する研究は Selye ${ }^{1)}$ (1936) が所謂 “General Adaptation Syndrome”なる 概念を発䒾するに及んで急激に展開され，就中その初期に見られる警告反応期に本系統か極妙て重要な役割 を演ずる等か淜らかとなつて以来，長足の進歩学遂げたので少るが，脳下垂体前葉よりのACTH の分泌機

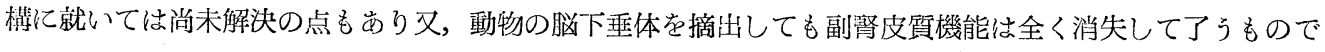


ないが，生体が諸種の危険刺㦸に嚗露された場合，之れに反応して副简皮質 Hormone の利用增大に応ぜん がために，脳下垂体前葉より ACTH の産生分泌が旺盛となり副掔皮質に刺战を与え，その Hormone の産 生分泌を盛んにすると云う一連の反応機構の存在は認妨られている。

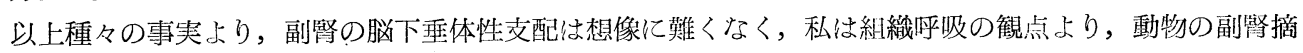
出を行つた際の脳下垂体の態度及び副㹂皮質 Hormone の代償作用如何を㭘索すべく実験を行つたが，脳下 垂体組織呼吸に及ばす影響改雨者共に特に差異を認》る事住出来なかつた。

\section{2) 甲狀腺と副腎}

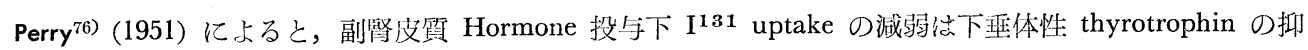
制によらないで，甲状腺への直接作用である加もしれない之述へている。小川等77) (1954) によれば, 副腎 摘出により甲状腺 $\mathrm{I}^{131}$ 摂取率住增加し，之れに Cortisone を投与少ると減少すると報し，小田等78) (1954) も同様の知見を得ている。尚，小川 (1955) 绾成熟雄性白鼠に ACTH, Cortisone を投与すると甲状腺

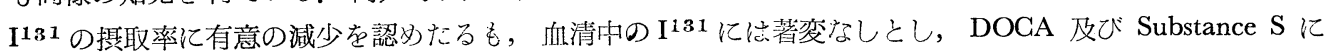

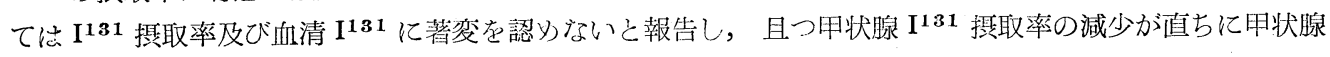
機能低下で㟧るとは云えないと述べている。吉弘 ${ }^{80)}$ (1955) は犬の甲状腺薄片に直接 Cortison：acetate を 加えると，その酸素消費量の低下する事から，副㛑皮質 Hormone が直接に甲状腺に作用して其の機能を抑 制する事を明らかにした。高折 ${ }^{81)}$ (1955) は Cortisone が正常白鼠の甲状腺の肥大増殖を来てさしたが，そ の機能を抑制し，DOCA 法甲状腺組織に著変を与えないが，其の機能を幾分低下せしぬたと報告している。 岩岡 ${ }^{82}$ （1954）经成熟白鼠を用心て Cortisone 投与群，DOGA 投与群，両側副腎摘出群，ACTH 投与群， Adrenalin 投与群亿於いて $\mathbf{I}^{\mathbf{1 3 1}}$ 追跡実験を行い, Wolfson の云う Corticogenic hypothyroidism の存在を 認めた。即ち Cortisone, DOCA で结 $\mathrm{I}^{131}$ 摂取能は低下し, 副餐摘出では甲状脉の $\mathrm{I}^{131}$ 摂取能は不変或い は上昇し，両側副筒摘出後も Cortisone により低下するが，DOCA によつては低下せずと述べている，田

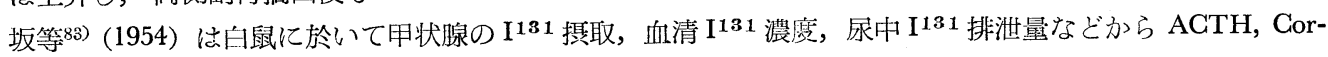
tisone，DOCA 及び Adrenalin 投与は甲状腺機能を低下させるものとなし，副繁摘出動物では Cortisone， DOCA による機能低下は比較的軽微であるとしている .

Bodansky \& Money ${ }^{84)}$ (1954), Ingbar ${ }^{85)}$ (1953) 其の他多くの人々は Cortisone が in vivo にて無作用又心 機能立進すると報告している. 大久保 ${ }^{86)}$ (1955) はカナリヤに Cortisone を約 1 ケ月与えても, 甲状腺に何 等組織学的変化を認㭁る事は出来ず，22日間 Cortisone を与えた場合下垂体に打ける甲状腺刺㦸 Hormone の含有量蛙正常のものと差がないと報告した。 O’Neal \& Heinbecker ${ }^{87)}$ (1953) は Cortisone を連用しても甲 状腺重量並びに組織像に変化がないとし，Higgins et al.88) (1951) は Cortisone 処置の白鼠は上皮細胞の高 さを増し，機能立進像を呈していると云い，Leblond et al.89) (1944) によ机ば，Stress は脳下垂体に於ける T.S.H. を增加させ，甲状腺を賦活させると報告している。室根90)（1957）虫家鬼に於いて，両側副腎摘出 後10日目頃より甲状腺虻組織学的に機能低下像を示し, 特に25日以後に於ける陳旧 Colloid 充満像及び滤胞 上皮細胞の極端な扁平化，加うるに糸粒体の動態の変化から上皮細胞に上る Colloid 吸収が何等かの機転に より抑制されているととを示すと報告している. 赤須91)（1956）は両側副㛑摘出動物の PBI の低下を認妨, 又 Cortisone 怯甲状腺機能を抑制するものでなく，Thyroxin の利用消失を高めるとなし，甲状腺と副简皮 質とが拮抗しているとは断言出来ず，生体に対して重要な臟器が Stress 時に，一方の機能低下を来たすてと 蛙首肯出来ないと述べている。

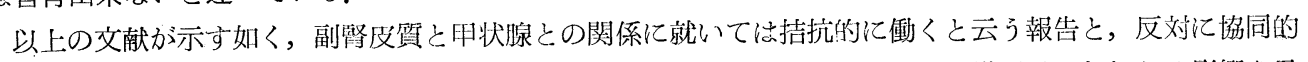
に作用すると云う報告がある。私の実験に於いては，两側副肾摘出が甲状腺の組織呼吸に如何なる影響を及 ぼすかを検索したるものであるが，対照に比して其の元進は極く僅かにして特に差異あるものとは認め難い． 又副腎摘出後 Cortisone 及び DOCA を投与せる場合も其の減弱度绕く僅かにして，特にその傾向に㟧り とは認好難”?

\section{3) 眴腺と副堅}


胸腺と副腎との関連性に就いての報告を見るに，Jaffe $\mathrm{e}^{22 ｝ \text { (1924) 结副腎摘出動物に於いて冽腺の再成を認 }$

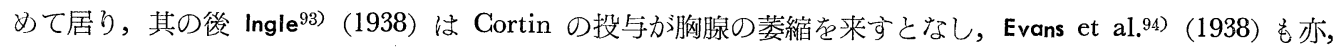
向副婜皮質 Hormone の投与により同様の所見を呈する事を報じている。 Reinhordt \& Holmes ${ }^{95}$ (1940) は $\mathrm{NaCl}$ によつて長期間，生存を保たしめた副㹂摘出白鼠の胸腺及び淋巴節の態度を検して，その組織重量の

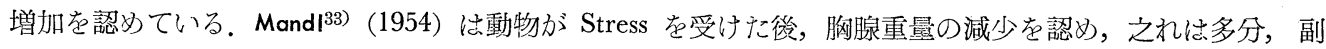
腎皮質 Hormone の分泌增加によるのであろうとしている。，又，成熟及び未熟白鼠の副腎摘出により胸腺重 量の増加を報じ，且つ DOGA は特に影響を及ばさないが，Cortisone は対照に比して著しい thymolytic action 走示すと述べている。 Dougherty \& White ${ }^{96)}$ (1954) も亦，胸腺及び淋巴組織の萎縮が Stress による 副腎皮質 Hormone 分泌增加に基因すると解している。柴田 ${ }^{97}$ （1954）纫雨側副腎摘出白鼠に於いて，胸腺 の酸素消費量及びP ${ }^{32}$ 吸収速度は著しく增加し, Cortisone 代償療法により胸腺重量, 酸素消費量, $\mathrm{P}^{3}$ 吸収 速度は娍少したと述心，且つての際胸腺の acidophil 細胞は淋巴球と反対に多くの場合增加していると報告 している。赤須等98,99) $(1952 ， 1954 ）$ は雌性白鼠に於ける Thorn-test 及び病理組織学的所見より，凟胸腺

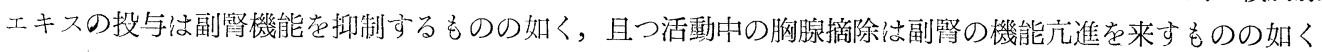
思われるとなし，又一方胸腺核酸量の検討より，胸腺は Glucocorticoids によつて細胞崩垻し，新生は相次

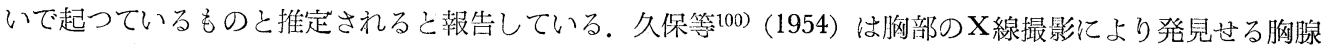
肥大览に就いて ACTH による Thorn-test を行い, 予備能の低下及び尿中 Chemocorticoid の低下を認》,

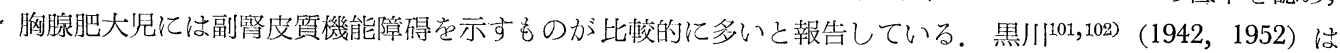
胸腺肥大と淋巴組織の肥大が重要視されていた所謂, 胸腺淋巴体質に於いて従来 Chrome 親和性細胞系の発 育不全が㐫げられていたが，副督哊質の及ならず皮質の萎縮乃至発育不全を認める事があり，且つ其の程度 のがり高度の状態行達するものが少なからざるを認妨, 本体質に於ける諸藏器特们分珌の異常, 発育不 全は抢そらく最も意義あるものにして，副督の如きは本邦人の平均重量の半ばに過ぎざるるの少なふらずと 報告している。岡本 ${ }^{103)}(1935)$ は胸腺淋巴体質に於ける脳下垂体前葉の組織学的研究に於いて，一般に元の

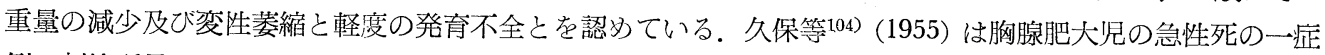
例の剖検所見及び生前に於ける Thorn-test, K-代謝異常及び胸腺陰影の経過より，副敁機能の低下が胸腚肥 大に先行していると思われると報告している。

私の実験成績を概括するに，雨側副等摘出白鼠の胸腺重量仗対照のそれに比して $48.2 \%$ 著明な增加を示 し，組織呼吸も亦，かなりの㠵進が証明された。文副腎摘出後 Cortisone を投与世る場合に於いて胸腺重量 は対照に比して $47.5 \%$ 著しき減少を来たし，組織呼吸も亦， $29.7 \%$ 著明なる抑制を招来した。又，副腎 摘出後 DOCA を投与せる場合の脍腺重量は対照に比して $20.2 \%$ の增加を認めたるも，組織呼吸に於いては 対照值と殆んど差異を認めない。

以上の成績より，急性副腎機能不全に於いては胸腺つ肥大を発来し，のみならず其の機能はえ進する。乙 の際 Glucocorticoid の一つである Cortisone の作用により胸腺は著朋な菱縮に 基く重量の減少を招来し, 且つその機能の娍弱を来たすをのと孝えられ，Mand133) (1954)の云う thymolytic action を肯定し得るもの で市る。 又 Mineralocorticoid の一つであるDOGA は組織呼吸の点に於いて，副婜摘出の影響を殆んど

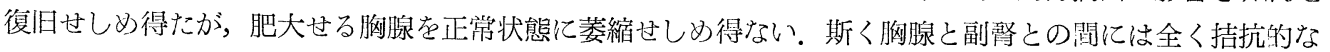

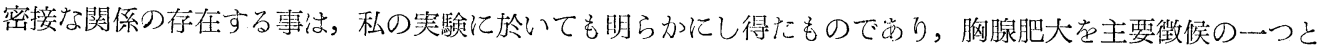
している所謂，胸腺体質乃至胸腺淋巴体貿に於いて副婜機能の異常は必然的に取りあげられなければならぬ ものと理解される。近時法医学分野に於いて，所謂コックリ病なるものが取上げられ一般の注視するとてろ となつているが，ての原因が果して Vitamine B の欠乏に基因するものなりや否や一一学る学者の唱うる如 く一一更に深く検討を要するもの之痛感される。

\section{4) 性腺と副腎}

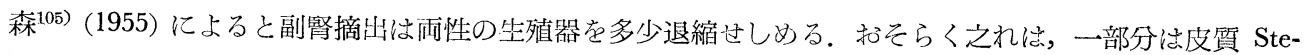
roid 中に含まれる性 Hormone の欠除に起因ずるものと思われるが，何処までが 単なる非特異性破壊及び 
其れ続いて起る生殖器萎縮であるか在決定する事は因難であるとしている，更㲹又動物は正常状態では殬 丸及び副腎皮質が Testoid の大部分を産生し，卵巣も亦，打そらくは胎盤も多少は Testoid を産生するも のと思うと述べている。.Warren et al.106)（1956）飞よれば，DOCA の如きもので適当な処置を受けてない 副腎不全の動物は，生殖系統の退化的変化及び “Livido” の失調を来すと述へ，且つ此等 DOC 亿上る効果 は個体が衰弱状態にあれ特異的な効果を発現すると考考えられないとしている. Antopol ${ }^{107)}$ (1950)による

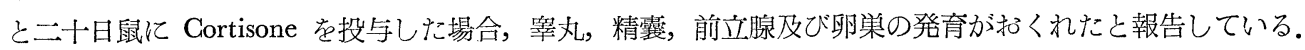
Greene et al. ${ }^{108)}$ (1939) 飞よれば Gonadotropin 或い结 Progesterone の投与出副腎摘出白鼠の生存日数を 延長すると述べている。鎮目 ${ }^{11)}$ (1955) は Addison 氏病患者に於ける月経週期及び性機能の変化の余り強く ないととから，副緊皮質 Hormone の減少は性機能に対し直接に，それ程に影響しないと述へて居り，皮質 Hormone の過剩状態に岕るCushing 氏症候群には無月経及び性欲減退が認められ，又 Cortisone 投与によ り月経が少くなり，不規則になる事は皮質 Hormone の性機能に対する影響を示すものと云えようと述べて いる.

Fitzhugh ${ }^{109)}$ (1937) 及び Freed et al.110) (1931) 飞よつて，成熟動物の副腎摘出は等丸に対して抑制作用を 及ぼすと主張されている。一方 Gaunt ${ }^{1111}$ （1933）及び Moore ${ }^{112)}$ (1953) は白鼠に於ける副腎摘出の結果, 㣮丸に何等の退化を認妨ないと報告している。 又 Winter et al.113) (1950) は白鼠に Cortisone を投与しても

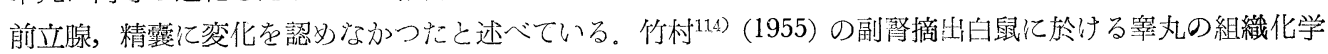
的研究によると, 摘出後日と共に精細胞の萎縮, 精子形成能の減弱及び間質の浮腫を認多, 10日後には精子

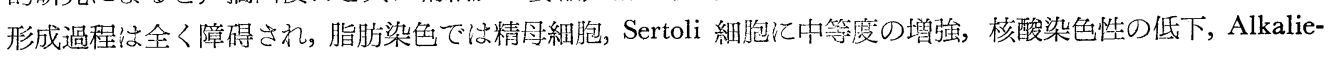
Phosphatase は減弱すると報告している.

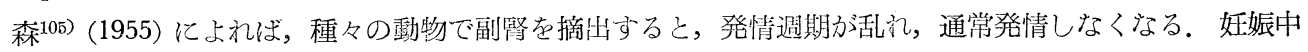
に副腎を摘出すると，適当な Corticoid の治療を行わない限り流産をする。授乳期間中に副婜を摘出すると， 乳汁分泌が停止すると述べている。.Parkes ${ }^{115)}$ (1945)，Courrier et al.116) (1953) 及び Zuckerman ${ }^{117)}$ (1953) に

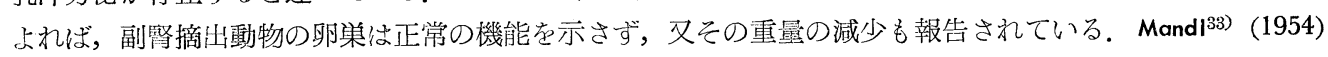
によれば，副腎摘出白鼠の卵栄结対照動物に比して卵胞と黄体が少ない. DCA ( $1 \mathrm{mg} / \mathrm{day})$ にる代償療法 は正常反応に回復出来ないが，Cortisone ( $1 \mathrm{mg} /$ day) に上つて正常反応に回復させ得ると述べている.

以上の文献の示す如く，性腺と副督との間に密接な関係の品る事结明らかにして，動物の副督を摘出する

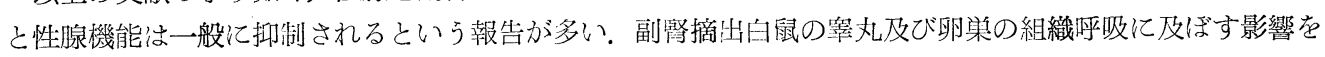

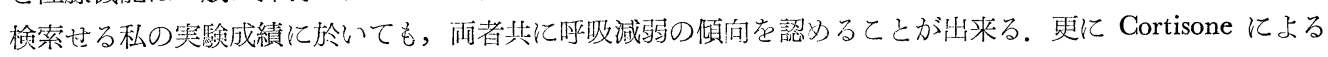
代償処置によつて，正常状態に復旧するを認奶たるも，DOCA によつては，卵樂に於いて影響を認めたる

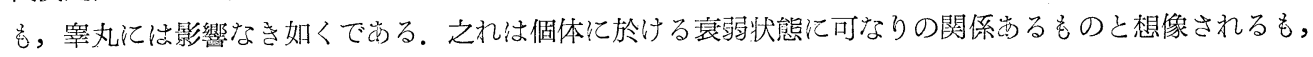

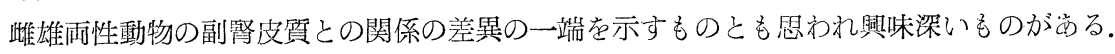

\section{第 4 章 結}

論

雌雄両性白鼠の両側副堅を摘出及び副婜を摘出後 Cortisone 又心 DOGA を投与せる場合に於ける各種内 分泌臟器の組織呼吸に見られる变異及び焳性白鼠に於ける副丳摘汕と胸腺重量との関係を梌索し, 要約して 次の結果を得た。

1) 両側副啃摘出白鼠の脳下垂体組織呼吸には著変を認力ない.

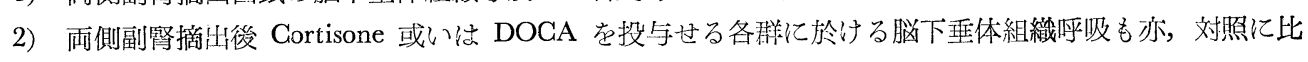
し著差を認め難い。

3）両側副腎摘出白鼠の甲状腺組織呼吸は特㠵進傾向に古るとは云えない。

4) 両側副腎摘出後 Cortisone 或いは DOCA を投与せる各群に於ける甲状腺組織呼吸も亦，対照に比し 特に減弱の傾向に岉るとは云えない。

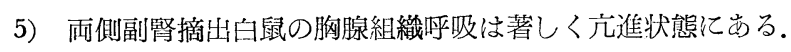


6) 両側副腎摘出後 Gortisone を投与すると，胸腺の組織呼吸は著しく減弱するが，DOCA を投与せる 場合は僅汃に㫕進傾向に竹る。

7）両側副腎摘出白鼠の胸腺重量は著しく增加し，副腎摘出㷋 Cortisone 投与により著しく重量減少を示 すが，DOCA 投与の場合怡稍々增加している。

8) 両側副婜摘出白鼠の鋅丸組織呼吸结減弱の傾向を示す。

9) 両側副腎摘出後 Cortisone 投与群の窣丸組織承吸出回復の徵を示すが，DOCA 投与群に於いては然 らず.

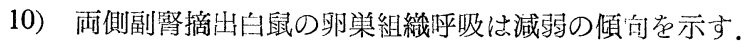

11）両側副腎摘出後 Cortisone 或いは DOGA 投与群の卵樂組織呼吸は共に回復の徵を示す.

（本研究に当り終始御想篤なる御指導と御校閲を睗つた恩師舘石教授に満腔の謝意を表します。尚種々御 助言を頂きました吉田助教授及び藤本講師に感謝します.)

\section{文献}

1) Selye, H. : Nature, $138: 32,1936$ (cit. 涻石 : ホルモン療法の実際，1956). 2) S.R. Tripton : Proc. Soc. Exper. Biol. \& Med. $45: 596,1940 . \quad 3)$ J.M. Crismon \& J. Field, 2D. : Am. J. Physiol. $130: 231$, $1940 . \quad 4)$ J.A. Russell \& A.E. Wilhelmi : J. Biol. Chem. $137: 713,1940 . \quad$ 5) Wolf-Heidegger, G., u. H. Waldmann : Z. Vitaminforshg. $12: 24,1942$ (Zit. Arch. Path. Anat. $320: 174,1951$ ). 6) W. Müller : Arch. Path. Anat. $320: 174,1951.77$ ) 秦: 四国医学雑誌, $6: 52,1955.8$ 8) 丸本, 伊 地，塚本：日本内分泌学会雑誌，30：185，1954. 9 9) Rowntree, L.G. \& Snell, A.M. : In Mayo Clinic Monographs, 1931. 10) Thorn, G.W., Dorrance, S.S. \& Day, E. : Ann. Int. Med. 16 : 1053, 1942 (9),

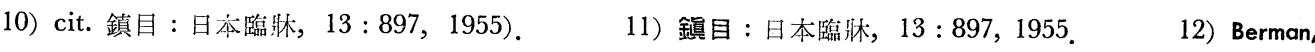
S., Hay, E.C. \& Selye, H. : Endocrinol. $41: 258,1947 . \quad 13)$ Friedgood, C.E., Vars, H.M. \& Zerbe, J.W. : Am. J. Physiol. $163:$ 354, $1950 . \quad$ 14) Cori, C. F. \& Cori, G. T. : J. Biol. Chem. $74:$ 473, 1927 (cit. 中尾: 副粲皮質ホルモン，1953)。 15) Lewis: Am. J. Physiol. $164: 617,1951 . \quad 16)$ White \& Rolf : Am. J. Physiol. $149: 404.1947 . \quad 17$ ) Hoffmayer : Acta Plgsica scand. $10: 31,1945$ (cit. 王子, 朝田：日本臨彇，14:200，1955).

18) Adlersberg : J. Clin. Endocrinol. $11: 67,1951 . \quad 19)$ Jiminez-Diaz, C. : Lancet $2: 1135,1936 . \quad$ 20) Lotspeich, W.D. : Endocrinol. $44: 314,1949 . \quad 21$ ) Talbott, J. H., Pecora, L. J., Melville, R.S. \& Consolazie, W.V.: J. Clin. Invest. $21: 107,1942 . \quad 22)$ 松 本他：日本内分泌学会雑誌，30：490，1954. 23) Loeb, R.F. : Harvey Lect. 100, 1941-42 (cit. K.E. Roberts Z R.F. Pitts : Endocrinol. $50: 51,1952) . \quad 24)$ Roemmelt, J.C., O.W. Sartorius \& R.F. Pitts : Am. J. Physiol. $159: 124,1949 . \quad 25)$ Guadino, M. \& M.F. Levitt : J. Clin. Invest. $28: 1487,1949 . \quad 26$ ) Harrison, H.E. \& D.C. Darrow : Am. J. Physiol. $125: 631,1939 . \quad 27)$ White, H.L., P. Heinbecker \& D. Rolf : Am. J. Physiol. 149 : 417, $1947 . \quad 28)$ K.E. Roberts \& R.F. Pitts : Endocrinol. $50: 51,1952$. 29) Smith, H.W. : The Kidney, Oxford University Press, 1951 (cit. K. E. Roberts \& R. F. Pitts : Endocrinol. $50: 51,1952$ ). 30) Barnett, H.L. \& H. Mc Namara : J. Clin. Invest. $28: 1498,1949 . \quad 31)$ Ferrebee, J.W., C. Ragan, D. Atchley \& R. F. Loeb : J.A.M.A. $113: 1725,1939 . \quad 32$ ) 根岸，丸茂 : 北関東 医学, $3: 229,1953.33)$ A.M. Mandl : J. Endocrinol. $11: 359,1954 . \quad 34)$ Teppermann, J., F.L. Engel \& C.N.H. Long : Endocrinol. 32 :373, $1943 . \quad 35)$ Miller, R.A. : Am. J. Anat. $86: 405,1950$. 36) 大樋：日本内分泌学会雑誌，31:468，1956. 37) 岡山：解剖学雑誌，29:4, 1954 . 福原：日本内分泌学会雑誌，28：182，1952. 39）宇佐美他：日本内分泌学会雑誌，28：181，1952. 40) 中尾: 副腎皮筫ホルモン，1953. 41) Firor, W. \& Grollman, A. : Am. J. Physiol. 103 : 686, 1933. 42) C. Bomskov \& K. Bahnsen : Arch. Exper. Path. $178: 1,1935.4$ 43) W.B. Connon : (cit. 舘石 : ホル 
モン療法の実際，1956). siol. Rev. 30 : 241, 1950.
44）小川他：内分必のつぞい，第 7 集， 1955.

46) 田坂他：内分泌のつどい，第 5 集，95，1953.
45) Sayers, G. : Phy47) Engel, F.L.: Recent Progress Hormone Research $6: 277,1951 . \quad 48)$ Engel, F.L. : Endocrinol. 50 : 462 , 1952. 49) Ingle, D.J., Meeks, R.C. \& Thomas, D.E. : Endocrinol. $49: 703,1951 . \quad 50)$ W. M. Booker, F. M. Da Costa, J.R. Tureman, C. Froix \& W. Jones : Endocrinol. $56: 413,1955 . \quad 51)$ Zarrow, M. : Proc. Soc. Exper. Biol. \&s Med. 50 : 135, 1942.

52) Sherr, G. : Science $116: 3025,1952$.

53) 萩原：日本薬理 学雑誌, $48: 135,1952$.

54) 田坂, 石橋, 貫洞, 荒岡：日本生理学雑誌，13:527，1951. 55) 石橋: 日本温泉気候学会雑誌, $17: 123,1953$. 56) 福田, 横関, 向島 : 日本生理学雑誌, $16: 273$, 1954.57) 松岡他：労㗢科学，31:121，1955.

58) 大野他: 労偅科学, $28: 747,1952$.

59) 鈴木 : 新潟医学会集誌, $64: 511,1950$.

$60 ）$ 滝童他: 内分泌，2:75, 1955.

61) 阿部 :

内分泌，3:211，1956.

62) Smifh, P.E. : Am. J. Anat. 45 : 205, 1930.

63) Smith, P.E. : Endocrinol. $38: 402,1946$.

64) Gemzell, C.A., D.C. van Dyke, C.A. Tobias \& H.M. Evans : Endocrinol. 49: 325,1951 .

65) Ingle, D.J. \& E.C. Kenndall : Science $86: 245,1937$.

66) Ingle, D.J. : Endocrinol. $24:$ 194, $1939 . \quad$ 67) Shizume, K. \& Levner, A.B. : J. Clin. Endocrinol. \& Metab. 14 : $1491,1954$. 68) Sydnor, K.L., Sayers, G., Brown, H. \& Tyler, F.H. : J. Glin. Endocrinol. \& Metab. 13 : 891, $1953 . \quad 69)$ Lloyd, C.W. : J. Clin. Endocrinol. $10: 318,1950$.

70) Slessor, A. : J. Clin. Endocrinol. $11: 700,1951$. 71) 矢野 : 内分泌のつぞい，第 4 集，123，1952.

72) Dochias, M. et al. : Am. J. Med. Sc. $222: 538$, 1951. 73) Sayers, G. \& Sayers, M. A. : Endocrinol. $40: 265,1947 . \quad 74)$ Sydnor, K. L., Sayers, G., Burguess, L. \& Heiselt, L. : Endocrinol. $55: 621,1954 . \quad 75)$ 渋沢 : 内分泌のつどい，第 8 集，278, 1956. 76) W.F. Perry : Endocrinol. $49: 284,1951$. 77) 小川, 板垣, 野村 : 北関東医学, $3: 86,1954$. 78 ) 小田, 岩岡, 片岡 : 内分泌, $1: 354,1954$. 79) 小川 : 内分泌, $2: 331,1955$ 80) 吉 弘：内分泌，2:140，1955. 81) 高折：日本内分泌学会雑誌，30:543，1955.

82) 岩岡 : 内 分泌, $1: 3,1954$.

83) 田坂, 小田：日本内分泌学会雑誌，30:113，1954.

84) Bodansky, 0 . \& W.L. Money : Endocrinol. $55: 173,1954$.

85) Ingbar, S.H. : Endocrinol. 53 : 171, 1953.

86)

大久保 : 動物学雑誌, $64: 99,1955.6$ 87) O’Neal, L.W. \& P. Heinbecker : Endocrinol. $53: 239,1953$. 88) Higgins, G.M., K.A. Woods \& E.C. Kendall : ibid. $48: 175,1951 . \quad$ 89) Leblond, C.P., J. Gross, W. Peacock et al. : Am. J. Physiol. $140: 671,1944.990)$ 室根：日本内分泌学会雑誌，33:121，1957. 91) 赤須：日本臨牀， $14: 181 ， 1956.92$ ) Jaffe, H.L. : J. Exp. Med. $40: 325$, 1924 (cit. W.O. Reinhardt \& R. O. Horlmes : Proc. Soc. Exp. Biol. \& Med. $45: 267,1940) . \quad$ 93) Ingle, D. J. : Proc. Soc. Exp. Biol. \& Med. 38 : 443, $1938 . \quad 94)$ Evaas, H.M. et al. : Proc. Soc. Exp. Biol. \& Med. $38: 419$, 1938. 95) W.O. Reinhardt \& R.O. Holmes : Proc. Soc. Exp. Biol. \& Med. $45: 267,1940.96$ 96) Dougherty, T.F. \& A. White : Endocrinol. $35: 1,1944 . \quad 97)$ 柴田 : Gumma J. Med. Sci. $3: 89,1954$. 98) 赤須他：日本内分泌学会雑誌，28：192，1952. 99）赤須他：日本内分泌学会雑誌，31：184，1955. 100）久保他：日本内分泌学会雑誌，30：93，1954。101) 黑川：実䀫医報，29:337，1942. 102)

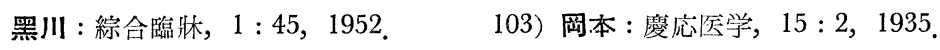
小肾科, $10: 67,1955$. 105) 森: 新撰内分泌学, Vol. II, 1955.

104) 久保他：臨床内科 106) Warren, R. Pauker \& L.R. Aronson : Endocrinol. 58 : 293, $1956 . \quad$ 107) Antopol, W. : Proc. Soc. Exp. Biol. \& Med. $73: 262$. 1950. 108) Greene, R.R., J.A. Wells \& A.C. Ivy : Proc. Soc. Exp. Biol. \&Med. $40: 83$, 1939.1109$)$ Fitzhugh, O.G. : Am. J. Physiol. $118: 677$, $1937 . \quad 110)$ Freed, S.C., B. Brownfield \& H.M. Evans : Proc. Soc. Exp. Biol. \& Med. 29 : 1, $1931 . \quad$ 111) Gaunt, R. : Am. J. Physiol. 193 : 494, 1933. Moore, C.R. : J. Glin. Endocrinol. \& Metab. 13 : 330, 1953. 113) Winter, C.A., Silber, R.H. \& Stoerk, H.C. : Endocrinol. $47: 60,1950$. 114) 竹村：日本病理学雑誌，44:116, 1955.

115) Parkes, A.S. : Physiol. Rev. 25 : 203, 1945. 116) Courrier, R., Baclesse, M. \& Marois, M. : J. Physiol. Path. gén 45 : 327, 1953. 117) Zuckerman, S. : In the Suprarenal Cortex. Ed. by J.M. Yoffe, 1953. 